\title{
Economic Assessment of Surface Water in the Harney Basin, Oregon
}

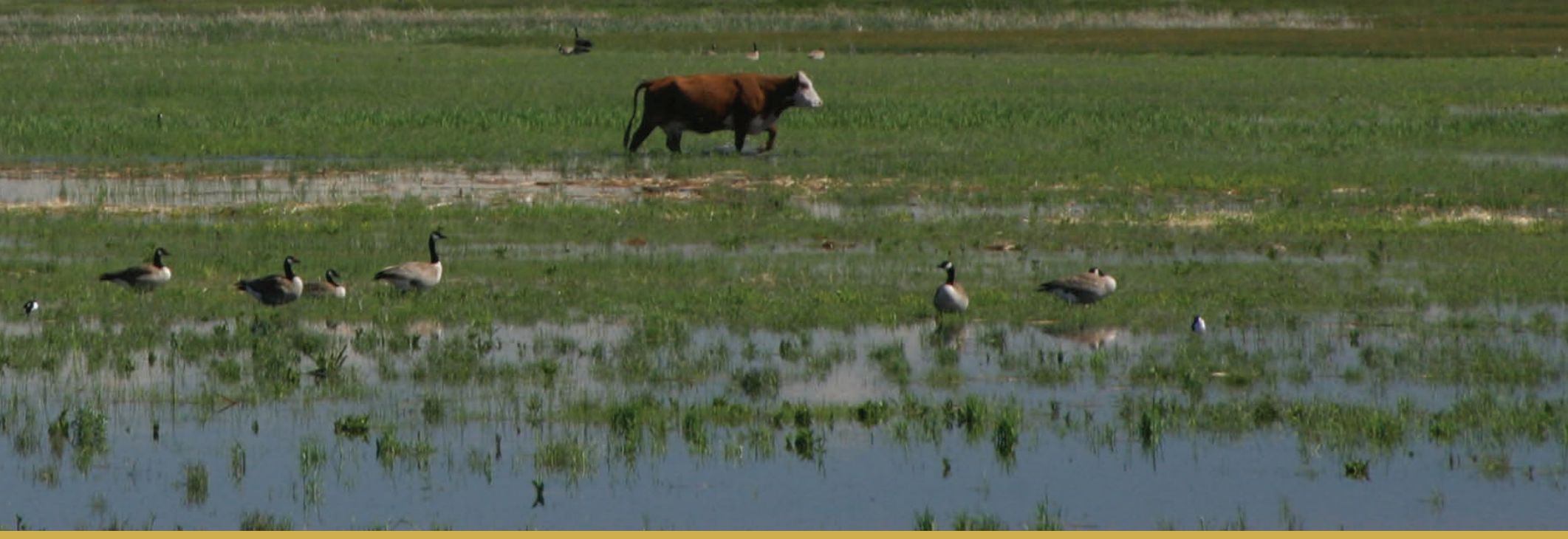

Open-File Report 2021-1087 
Cover. Photograph of birds and cattle grazing on flood-irrigated pasture in the Harney Basin, Oregon, with Steens Mountain in the background. Photograph by Barbara Wheeler, U.S. Fish and Wildlife Service volunteer. 


\section{Economic Assessment of Surface Water in the Harney Basin, Oregon}

By Lucas S. Bair, Matthew Flyr, and Christopher Huber

Open-File Report 2021-1087 


\section{U.S. Geological Survey, Reston, Virginia: 2021}

For more information on the USGS — the Federal source for science about the Earth, its natural and living resources, natural hazards, and the environment-visit https://www.usgs.gov or call 1-888-ASK-USGS.

For an overview of USGS information products, including maps, imagery, and publications, visit https://store.usgs.gov.

Any use of trade, firm, or product names is for descriptive purposes only and does not imply endorsement by the U.S. Government.

Although this information product, for the most part, is in the public domain, it also may contain copyrighted materials as noted in the text. Permission to reproduce copyrighted items must be secured from the copyright owner.

Suggested citation:

Bair, L.S., Flyr, M., and Huber, C., 2021, Economic assessment of surface water in the Harney Basin, Oregon: U.S. Geological Survey Open-File Report 2021-1087, 43 p., https://doi.org/10.3133/ofr20211087.

ISSN 2331-1258 (online) 


\section{Acknowledgments}

This research was supported by the U.S. Fish and Wildlife Service and the High Desert Partnership. The authors would like to thank Brenda Smith and Chad Karges (High Desert Partnership); Jeff Mackay, Ryan Roberts, Erin Carver, Carey Goss, Edwin Sparks, and Alex Martinez (U.S. Fish and Wildlife Service); Mark Owens (former Harney County Commissioner); Lola Johnson (Harney County Chamber of Commerce); Tara Thissell, Sophia Kim, and Mandy DeCroo (Bureau of Land Management); Ty Cronin (U.S. Department of Agriculture, Forest Service); Billy Gascoigne and Chris Colson (Ducks Unlimited); Ed Contreras (Intermountain West Joint Venture); Jordan Beamer, Mellony Hoskinson, and Kenneth Stahr (Oregon Water Resources Department);Teresa Wicks (Portland Audubon); Tony Svejcar, Chad Boyd and Dustin Johnson (Eastern Oregon Agricultural Research Center Burns Station); Dan Nichols; Gary Marshall; and Mark Doverspike in support of this research. 


\section{Contents}

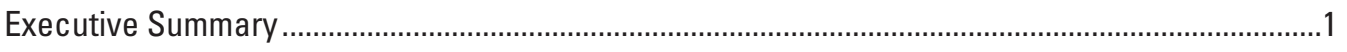

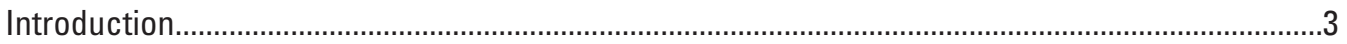

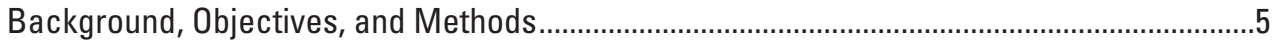

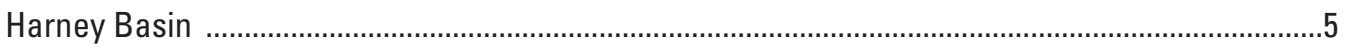

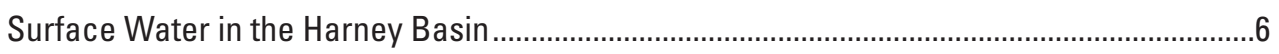

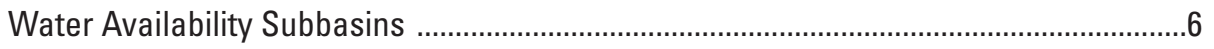

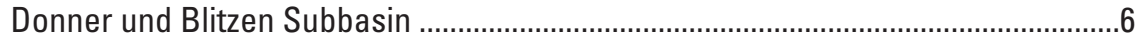

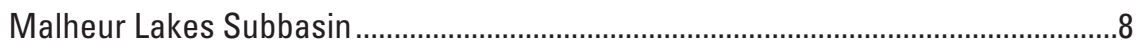

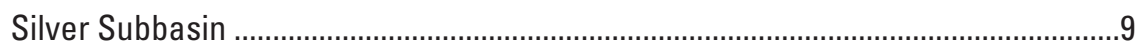

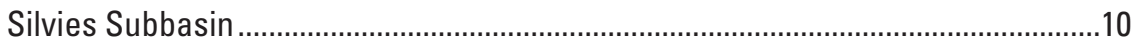

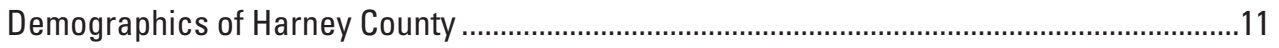

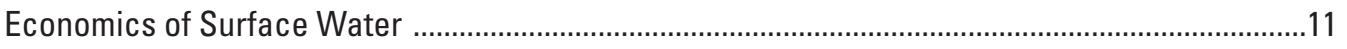

Economic Valuation Methods ........................................................................................11

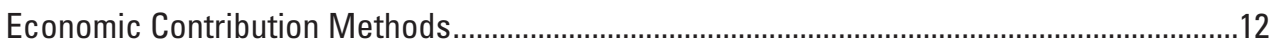

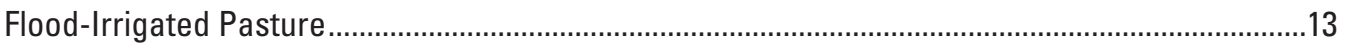

Flood-Irrigated Pasture Data .............................................................................................13

Economic Benefit of Surface Water for Flood-Irrigated Pasture ..........................................15

Crop Enterprise Budgets .......................................................................................15

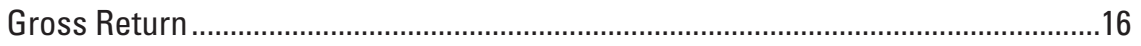

Variable and Fixed Cost ...........................................................................................16

Net Return and the Economic Benefit of Water ....................................................17

Regional Economic Contribution of Flood Irrigation ..........................................................19

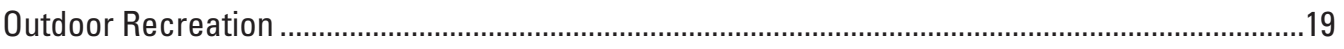

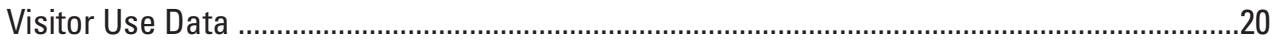

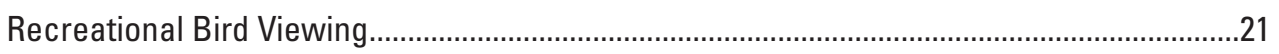

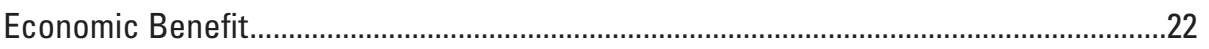

Regional Economic Contributions .........................................................................22

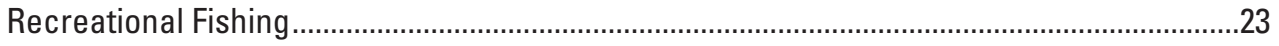

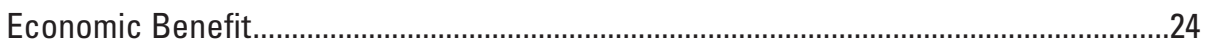

Regional Economic Contributions .........................................................................25

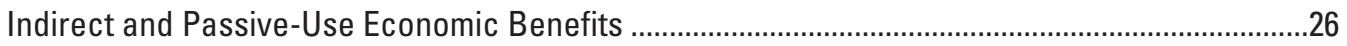

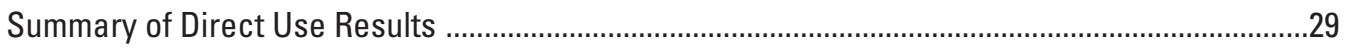

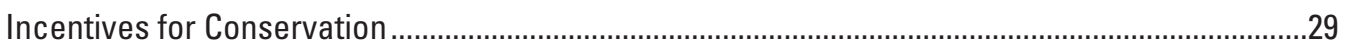

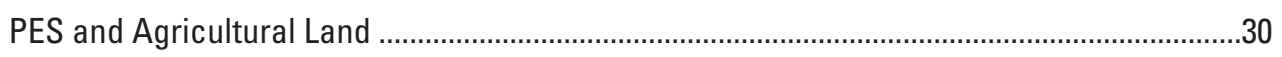

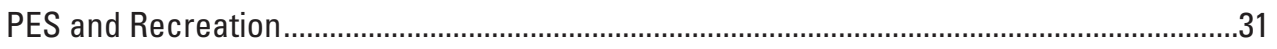

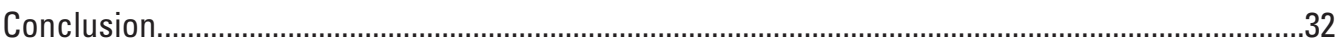

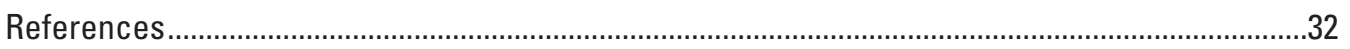

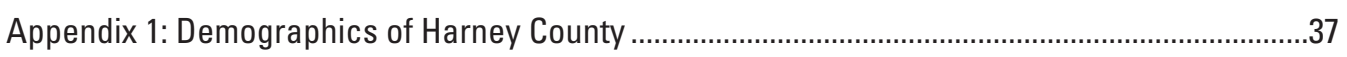

Appendix 2: Total Economic Value per Household for Fish Species .................................................40 


\section{Figures}

1. Map of Harney Basin, Oreg., showing four water availability subbasins ...........................4

2. Monthly streamflow and annual volume of Oregon Department of Water Resources water availability subbasins at the 50 -percent exceedance level....................................6

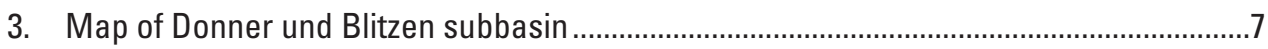

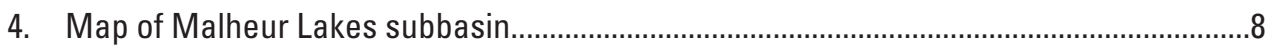

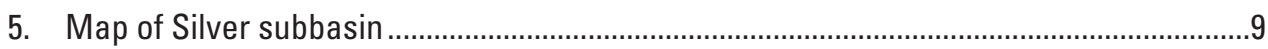

6. Map of Silvies subbasin..........................................................................................10

7. Surface water consumptive use for flood irrigation by subbasin at the 50 -percent

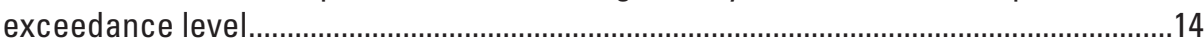

8. Percentage of primary activity types for most recent trip to Malheur National Wildlife Refuge, Oreg ..................................................................................................

1.1. Population distribution of Harney County..................................................................37

\section{Tables}

ES1. Flood-Irrigated pasture water use and area by subbasin in the Harney Basin, Oreg., at the 50-percent exceedance level.

ES2. Net economic benefit of surface water for flood-irrigated pasture in the Harney Basin, Oreg.

ES3. Economic contributions associated with flood-irrigated pasture in the Harney Basin, Oreg.

ES4. Total annual days bird viewing and recreational fishing at the Malheur National Wildlife Refuge and Bureau of Land Management Donner und Blitzen River system near Page Springs, Oreg.

ES5. Economic benefit of bird viewing at the Malheur National Wildlife Refuge and recreational fishing in the Harney Basin, Oreg.

ES6. Economic contributions associated with bird viewing and recreational fishing in the Harney Basin, Oreg

1. Consumptive water use for flood irrigation in the Harney Basin, Oreg., at the 50-percent exceedance level.

2. Flood-irrigated pasture water use and area in the Harney Basin, Oreg., at the 50-percent exceedance level.

3. Average annual area of flood-irrigated pasture in the Harney Basin, Oreg., 2010-2019.

4. Multiple estimates of annual area of flood-irrigated pasture in the Harney Basin, Oreg.

5. Regional all-hay prices (per ton) in 2019..................................................................16

6. Crop budget costs and returns of flood-irrigated pasture in the Silvies subbasin, Oreg.....

7. Crop budget costs and returns of flood-irrigated pasture in the Malheur National Wildlife Refuge, Oreg....

8. Economic returns to flood-irrigated pasture in the Harney Basin, Oreg ...... 18 
9. Economic contributions associated with flood-irrigated pasture in the Harney Basin, Oreg

10. Annual number of visitors to the Malheur National Wildlife Refuge, Oreg., from 2012 to 2019.

11. Number of visitors, length of stay, and number of days fishing and bird viewing in the Malheur National Wildlife Refuge, Oreg.

12. Total days fishing and bird viewing at the Malheur National Wildlife Refuge and Bureau of Land Management Donner und Blitzen River system near Page Springs, Oreg

13. Economic benefit of bird viewing at the Malheur National Wildlife Refuge, Oreg .........22

14. Annual days bird viewing at the Malheur National Wildlife Refuge, Oreg..... . .22

15. Expenditures for bird viewing at the Malheur National Wildlife Refuge in the Harney Basin, Oreg

16. Percentage of expenditures for bird viewing in Harney County, Oreg., allocated to IMPLAN sectors.

17. Economic contributions from total expenditures (local and non-local) for bird viewing in the Harney Basin, Oreg

18. Economic benefits of recreational fishing at the Malheur National Wildlife Refuge and Bureau of Land Management Donner und Blitzen River system near Page Springs, Oreg.

19. Annual days recreational fishing at the Malheur National Wildlife Refuge and Bureau of Land Management Donner und Blitzen River system near Page Springs, Oreg

20. Expenditures for recreational fishing at the Malheur National Wildlife Refuge and Bureau of Land Management Donner und Blitzen River system near Page Springs, Oreg.

21. Economic contributions from total expenditures (local and non-local) for fishing in the Harney Basin, Oreg

22. Economic value per household of threatened, endangered, and rare fish species .......27

23. Economic benefit by surface water use in the Harney Basin, Oreg ...............................27

24. Annual economic contribution by surface water use in the Harney Basin, Oreg...........29

1.1. Population and demographic statistics for Harney County and the State of Oregon......37

1.2. Total number of civilian employees ( 16 years and older) and percentage of employees by industry for Harney County and the State of Oregon

2.1. Total economic value per household for fish species 


\section{Abbreviations}

$\begin{array}{ll}\text { AUM } & \text { animal unit month } \\ \text { Basin } & \text { Harney Basin } \\ \text { BLM } & \text { Bureau of Land Management } \\ \text { BTM } & \text { benefit transfer method } \\ \text { CCP } & \text { Comprehensive Conservation Plan } \\ \text { COA } & \text { Census of Agriculture } \\ \text { CVM } & \text { contingent valuation method } \\ \text { EOIP } & \text { Environmental Quality Incentives Program } \\ \text { ERS } & \text { Economic Research Service } \\ \text { FWS } & \text { U.S. Fish and Wildlife Service } \\ \text { FS } & \text { USDA Forest Service } \\ \text { HBWI } & \text { Harney Basin Wetlands Initiative } \\ \text { IMWJV } & \text { Intermountain West Joint Venture } \\ \text { MNF } & \text { Malheur National Forest } \\ \text { MNWR } & \text { Malheur National Wildlife Refuge } \\ \text { MRIO } & \text { multi-regional input output } \\ \text { NAICS } & \text { North American Industry Classification System } \\ \text { NASS } & \text { National Agricultural Statistics Service } \\ \text { NRCS } & \text { Natural Resources Conservation Service } \\ \text { NVUM } & \text { National Visitor Use Monitoring } \\ \text { ODFW } & \text { Oregon Department of Fish and Wildlife } \\ \text { OWRD } & \text { Oregon Water Resources Department } \\ \text { PES } & \text { payment for ecosystem services } \\ \text { RAPP } & \text { Refuge Annual Performance Plan } \\ \text { RCs } & \text { response coefficients } \\ \text { RUVD } & \text { Recreation Use Values Database } \\ \text { USDA } & \text { U.S. Department of Agriculture } \\ \text { USGS } & \text { U.S. Geological Survey } \\ \text { WARS } & \text { Water Availability Reporting System } \\ & \\ \text { HNG }\end{array}$





\title{
Economic Assessment of Surface Water in the Harney Basin, Oregon
}

\author{
By Lucas S. Bair, ${ }^{1}$ Matthew Flyr, ${ }^{2}$ and Christopher Huber ${ }^{1}$
}

\section{Executive Summary}

The Harney Basin is a closed river basin in southeastern Oregon. Surface water in the basin is used for a variety of social, economic, and ecological benefits. While some surface water uses compete with one another, others are complementary or jointly produce multiple beneficial outcomes. The objective of this study is to conduct an economic assessment of surface water in the basin as it relates to wet meadow pasture production and outdoor recreation. Given the complex interactions between surface water management on public and private land and the various goods and services that are derived from adequate water resources, an economic assessment of surface water management can be used to assist future decision making in the basin.

This report quantifies the economic benefits and regional economic contributions of activities that are directly or indirectly related to the allocation and use of surface water in the Harney Basin, focusing on agricultural production and outdoor recreation. We characterize the economic importance of surface water use for these activities using several economic approaches. Broadly, there are two distinct ways to evaluate the economic significance of surface water in the basin. The first is the economic benefit of surface water, which in this case measures net economic benefits of flood-irrigated pasture and recreation. Net economic benefit is the value an individual agricultural producer or recreation consumer holds in excess of production or trip costs, respectively. The second measure - economic contributions - estimates the jobs and economic activity supported by expenditures in an economy, in this case as a result of flood-irrigated pasture production or recreation trip costs. This study estimates the economic contributions of pasture production and recreation trip expenditures to both the basin and the surrounding region, defined in this study as the State of Oregon.

Harney County is a rural county in southeast Oregon and, like many rural counties, one of the main economic sectors is agriculture. Agricultural production in the county is primarily cattle and calves and hay crops. Surface water diversions from rivers and creeks in the Harney Basin are used to inundate

${ }^{1}$ U.S. Geological Survey.

${ }^{2}$ National Park Service. flood plains for irrigated pasture production. Forage produced from irrigated pasture is used to supplement winter feed for cow-calf operations. Without the production on flood-irrigated pasture, cow-calf operations would have to rely on off-ranch sources of forage on the open market. There are approximately 106,530 acres of flood-irrigated pasture in the basin in an average water year, or at the 50-percent exceedance level (table ES1).

Table ES1. Flood-Irrigated pasture water use and area by subbasin in the Harney Basin, Oreg., at the 50-percent exceedance level.

[Annual consumptive use is reported at the 50-percent exceedance level by the Oregon Water Resources Department in the Water Availability Reporting System (Oregon Water Resources Department, 2020)]

\begin{tabular}{lccc}
\hline \multicolumn{1}{c}{ Subbasin } & $\begin{array}{c}\text { Annual } \\
\text { consumptive } \\
\text { use (acre-ft) }\end{array}$ & $\begin{array}{c}\text { Consumptive } \\
\text { use per acre } \\
\text { (acre-ft) }\end{array}$ & $\begin{array}{c}\text { Estimated } \\
\text { flood-irrigated } \\
\text { pasture (acres) }\end{array}$ \\
\hline Silvies & 89,068 & 1.56 & 57,095 \\
$\begin{array}{l}\text { Donner und } \\
\text { Blitzen }\end{array}$ & 40,494 & 1.54 & 26,295 \\
\hline $\begin{array}{l}\text { Silver } \\
\text { Malheur Lakes }\end{array}$ & 22,409 & 1.54 & 14,551 \\
\hline \multicolumn{1}{c}{ Harney } & 13,227 & 1.54 & 8,589 \\
\hline Basin total & $\mathbf{1 6 5 , 1 9 7}$ & $\mathbf{1 . 5 5}$ & $\mathbf{1 0 6 , 5 3 0}$ \\
\hline
\end{tabular}

Estimates of short-run economic benefits of surface water for irrigation are made using individual crop enterprise budgets. Annual irrigation benefits are calculated by subtracting the farm production costs from gross farm income on a per acre basis. Production costs include return to capital, labor, land, and management, so the net farm income represents the economic benefit of surface water for irrigation. Crop enterprise budgets are calculated on a per acre basis to determine the return per acre foot. The total net return, or economic benefit of surface water for flood-irrigated pasture, is estimated at $\$ 17.2$ million in an average water year (table ES2).

Beyond the economic benefit of surface water, this water also contributes to regional economic activity. One method to estimate the economic contribution of surface water used for irrigation is to estimate the economic activity associated with grazing of flood-irrigated pasture. This approach assumes flood irrigation makes possible a certain level of grazing, and 
grazing is associated with a certain level of economic activity that can be estimated. Given this relationship, grazing of flood-irrigated pasture in the Harney Basin supports 718 jobs, $\$ 11.6$ million in labor income, $\$ 40.1$ million in economic output, and \$22.1 million in value added in the State of Oregon, including both inside and outside the basin (table ES3).

Table ES2. Net economic benefit of surface water for floodirrigated pasture in the Harney Basin, Oreg.

[Return per acre foot is estimated by dividing the return per acre by the estimated consumptive use of water per acre (Oregon Water Resources Department, 2020). The estimated return per acre-foot is based on water availability at the 50-percent exceedance level]

\begin{tabular}{lccc}
\hline \multicolumn{1}{c}{ Subbasin } & $\begin{array}{c}\text { Return per } \\
\text { acre-foot }\end{array}$ & $\begin{array}{c}\text { Total volume } \\
\text { (acre-ft) }\end{array}$ & $\begin{array}{c}\text { Total economic } \\
\text { benefit }\end{array}$ \\
\hline Silvies & $\$ 105$ & 89,068 & $\$ 9,352,140$ \\
$\begin{array}{l}\text { Donner und } \\
\text { Blitzen }\end{array}$ & $\$ 104$ & 17,394 & $\$ 1,808,976$ \\
$\begin{array}{l}\text { Silver } \\
\text { Malheur Lakes }\end{array}$ & $\$ 104$ & 22,409 & $\$ 2,330,536$ \\
$\begin{array}{l}\text { Malheur National } \\
\text { Wildlife Refuge }\end{array}$ & $\$ 102$ & 13,227 & $\$ 1,375,608$ \\
\hline \multicolumn{1}{c}{ Harney Basin } \\
total
\end{tabular}

Table ES3. Economic contributions associated with floodirrigated pasture in the Harney Basin, Oreg.

\begin{tabular}{lcccr}
\hline $\begin{array}{c}\text { Economic } \\
\text { impact type }\end{array}$ & $\begin{array}{c}\text { Supporting } \\
\text { jobs }\end{array}$ & $\begin{array}{c}\text { Labor } \\
\text { income }\end{array}$ & $\begin{array}{c}\text { Economic } \\
\text { output }\end{array}$ & Value added \\
\hline Direct effect & 491 & $\$ 2,575,917$ & $\$ 15,973,225$ & $\$ 7,886,006$ \\
$\begin{array}{l}\text { Secondary } \\
\text { effect }\end{array}$ & 227 & $\$ 9,063,594$ & $\$ 24,087,223$ & $\$ 14,221,486$ \\
\hline Total effect & $\mathbf{7 1 8}$ & $\mathbf{\$ 1 1 , 6 3 9 , 5 1 1}$ & $\mathbf{\$ 4 0 , 0 6 0 , 4 4 8}$ & $\mathbf{\$ 2 2 , 1 0 7 , 4 9 2}$ \\
\hline
\end{tabular}

In addition to flood-irrigated pasture, bird viewing and fishing are two important outdoor recreation activities that rely on surface water flows in the Harney Basin. For example, each spring, the region hosts the Harney County Migratory Bird Festival to celebrate migratory birds that rely on the Malheur National Wildlife Refuge (MNWR) and surrounding private flood-irrigated pasture for stopover and nesting habitat. Recreational fishing for native redband trout (Oncorhynchus mykiss spp.) is popular throughout the region as well.

There is an estimated total of 54,889 bird viewing and 8,000 fishing days in the Harney Basin per year (table ES4). These visitation data are drawn from the MNWR Annual Performance Plan (RAPP) (R. Roberts, written commun., 2019) and from fishing data compiled by the Oregon Department of Fish and Wildlife (1980). These estimates should be viewed as conservative because, (1) they only capture bird viewing days at the MNWR and do not capture
Table ES4. Total annual days bird viewing and recreational fishing at the Malheur National Wildlife Refuge and Bureau of Land Management Donner und Blitzen River system near Page Springs, Oreg.

\begin{tabular}{llc}
\hline \multicolumn{1}{c}{ Land unit } & $\begin{array}{c}\text { Annual days } \\
\text { fishing }\end{array}$ & $\begin{array}{c}\text { Annual days } \\
\text { bird viewing }\end{array}$ \\
\hline Malheur National Wildlife Refuge $^{1}$ & 1,642 & 54,889 \\
Donner und Blitzen River System $^{2}$ & 6,358 & N/A \\
\hline Total & $\mathbf{8 , 0 0 0}$ & $\mathbf{5 4 , 8 8 9}$ \\
\hline
\end{tabular}

${ }^{1}$ Data from U.S. Fish and Wildlife Service (2019).

${ }^{2}$ Data from Oregon Department of Fish and Wildlife (1980).

bird viewers that exclusively visit other Federal or private lands, and (2) the fishing visits are limited to MNWR and Page Springs and do not capture fishing at other locations in the basin. However, we believe they closely reflect the majority of bird viewing and fishing days that occur in the basin. These estimates are used to quantify annual economic benefits to bird viewers and anglers and the economic contributions of their expenditures to local economic activity.

The annual economic benefit of bird viewing totals nearly \$2.9 million (table ES5). For recreational fishing the annual economic benefit totals $\$ 526,800$ (table ES5). These economic benefit measures reflect the overall economic value

Table ES5. Economic benefit of bird viewing at the Malheur National Wildlife Refuge and recreational fishing in the Harney Basin, Oreg.

[Benefit in 2020 dollars]

\begin{tabular}{lrcc}
\hline Recreation activity & Days & Benefit per day & Annual benefit \\
\hline Bird viewing & 54,889 & $\$ 52.16$ & $\mathbf{\$ 2 , 8 6 3 , 0 1 0}$ \\
Fishing & 8,000 & $\$ 65.85$ & $\mathbf{\$ 5 2 6 , 8 0 0}$ \\
\hline
\end{tabular}

bird viewers and anglers receive, in excess of trip costs, from engaging in these activities in the Harney Basin.

Employment and business activities are supported by local and non-local recreation visitor expenditures related to bird viewing and fishing in the Harney Basin. Combined spending from local and non-local bird viewers and anglers in the basin supports 85 jobs, $\$ 2.8$ million in labor income, $\$ 7.2$ million in economic output, and \$4.1 million in value added in the State of Oregon, including both inside and outside the basin (table ES6); we find the vast majority of these contributions occur in Harney County.

The economic benefits and contributions documented in this report are related to goods and services directly supported by surface water in the Harney Basin, specifically flood-irrigated pasture, fishing, and bird viewing. However, beyond these direct uses, there are other economic benefits in the form of indirect or passive uses that this assessment does 
Table ES6. Economic contributions associated with bird viewing and recreational fishing in the Harney Basin, Oreg.

\begin{tabular}{lcccc}
\hline $\begin{array}{c}\text { Economic } \\
\text { impact type }\end{array}$ & $\begin{array}{c}\text { Supporting } \\
\text { jobs }\end{array}$ & $\begin{array}{c}\text { Labor } \\
\text { income }\end{array}$ & $\begin{array}{c}\text { Economic } \\
\text { output }\end{array}$ & Value added \\
\hline Direct effect & 67 & $\$ 2,184,141$ & $\$ 4,924,079$ & $\$ 2,881,519$ \\
$\begin{array}{c}\text { Secondary } \\
\text { effect }\end{array}$ & 18 & $\$ 661,806$ & $\$ 2,307,707$ & $\$ 1,235,909$ \\
\hline \multicolumn{1}{c}{ Total effect } & $\mathbf{8 5}$ & $\mathbf{\$ 2 , 8 4 5 , 9 4 7}$ & $\mathbf{\$ 7 , 2 3 1 , 7 8 6}$ & $\mathbf{\$ 4 , 1 1 7 , 4 2 8}$ \\
\hline
\end{tabular}

not capture. Flood-irrigated pasture in the basin may provide ecosystem services that are indirectly used and benefit society, such as carbon sequestration, nutrient cycling, and pollination. Individuals that view or hunt migratory birds outside of the basin along the migratory route are also indirectly benefitting from the habitat provided within the basin. Passive-use values include existence values (the value in maintaining a resource regardless of actual or intended direct use) and bequest values (the value in maintaining a resource for the enjoyment of future generations). For example, people may place an economic value on maintaining migratory birds along the flyway regardless of whether they visit the basin. Research has shown that the economic benefit for the preservation of wildlife can be large when aggregating across households in a region or the United States. Other research has demonstrated that there is also individual and collective amenity and lifestyle value associated with working landscapes. Although we do not attempt to quantify the value of indirect or passive use, the evidence suggests that the total economic benefit for the production of ecosystem services provided by the management of surface water in the basin may be large.

Use of surface water in the Harney Basin for the joint production of irrigated pasture, migratory bird habitat, and native fish conservation is a dynamic process. There are various ecological and social factors that determine the longterm sustainability of these benefits. One approach to improve the resiliency in an uncertain future is to better understand the joint production of flood-irrigated pasture and habitat. In the current institutional arrangement, private landowners do not capture or necessarily manage for the benefits of the production of habitat. This exposes habitat supported by private lands to market risks, such as changes to commodity prices (cattle prices, hay prices) or the costs of production (labor, energy, transportation), and risks of low water availability during periods of drought. Financial incentives for conservation on private land are an opportunity to promote resilient working landscapes and wildlife habitat. Payment for ecosystem services (PES) is one type of arrangement that could be used to maintain or increase the production of beneficial ecosystem services (such as habitat) supported by private land.
The Harney Basin has a unique opportunity to capture economic benefits from private recreationists for conservation. To do this, regional organizations and private landowners in the basin would need to develop a credible program that cost-effectively maintains or improves habitat. A credible program would demonstrate, through scientific monitoring and research, that conservation actions lead to tangible benefits. The program would also need to reduce transaction costs between landowners and recreationists, through an online presence and (or) onsite setting, to facilitate a PES program. Finally, to fully engage visitors in the basin, the program would need to overcome the public-good nature of the recreational experience and add value to the visitor experience through exclusive access to private land or other viewing opportunities.

The economic benefit and regional contribution estimates in this report are necessary to inform surface water management in the Harney Basin, including the potential implementation of a PES program. We estimate economic benefit and contributions from each use of surface water separately, but the production of goods and services from surface water use is not an independent process. Nonetheless, a basic understanding of the economic benefits and contributions of flood-irrigated pasture and recreation provides a foundation for assessing tradeoffs that occur with future surface water management and the joint production of forage and habitat. Improved monitoring and research related to the joint production of forage and habitat on flood-irrigated pasture and better collection of recreation use visitor data in the basin would further the ability to enhance the joint production of goods and services from surface water use.

\section{Introduction}

The Harney Basin is a closed river basin in southeastern Oregon (fig. 1). Surface water in the basin is used for a variety of social, economic, and ecological benefits. While some surface water uses compete with one another, others are complementary or jointly produce multiple beneficial outcomes. For example, flood irrigation with surface water is a widespread agricultural practice in the basin that also maintains irrigated pasture habitat necessary for migrating birds. However, agricultural surface water withdrawals reduce instream flow that may impact native fish, including redband trout (Oncorhynchus mykiss spp.). The Malheur National Wildlife Refuge (MNWR) and other basin stakeholders are interested in understanding the interactions between surface water use for irrigated pasture, outdoor recreation, and native fish conservation in the basin. Given these complexities, an economic assessment can highlight the tradeoffs of alternative surface water management outcomes in the basin. 


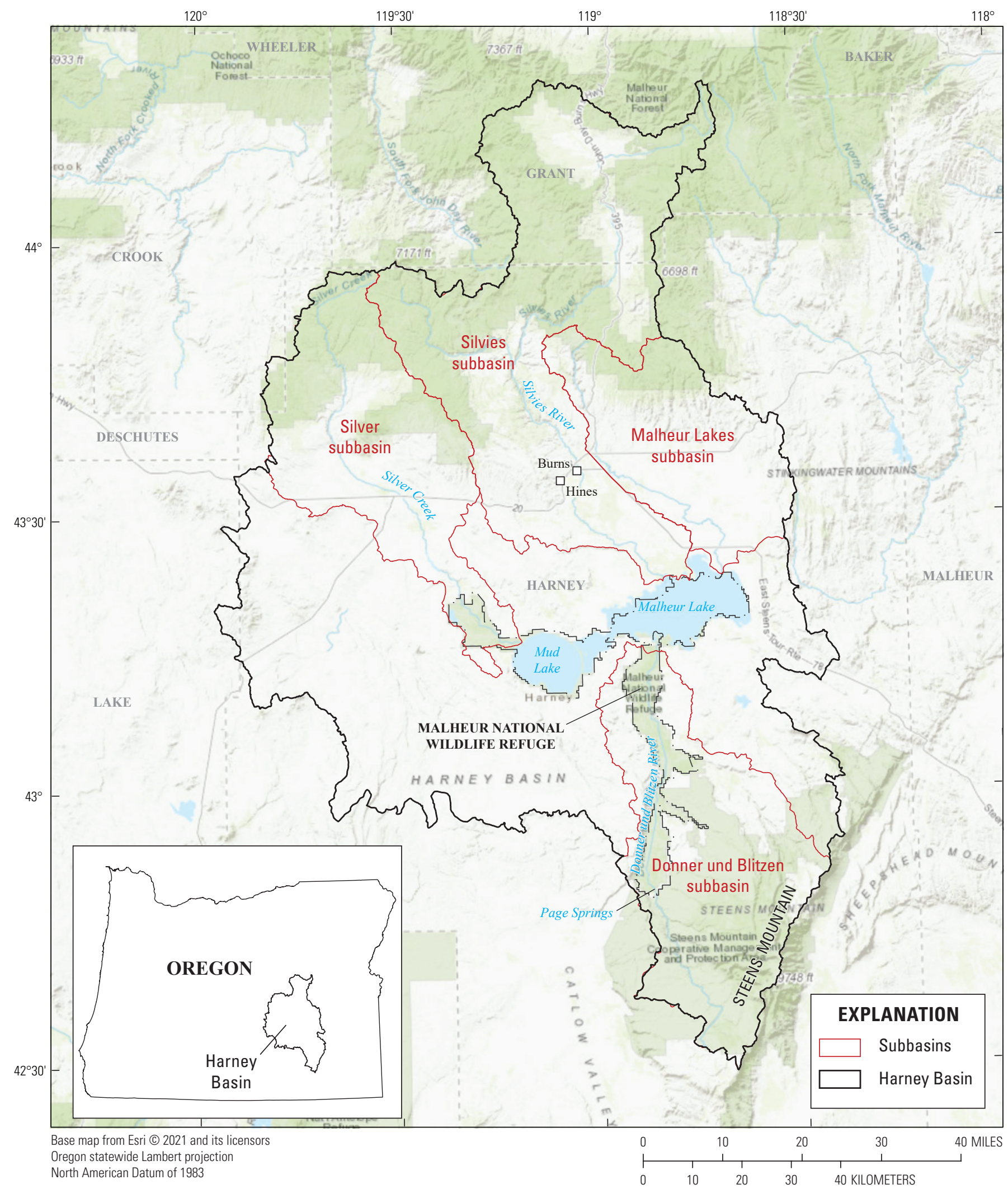

Figure 1. Map of Harney Basin, Oreg., showing four water availability subbasins. 


\section{Background, Objectives, and Methods}

The objective of this study is to conduct an economic assessment of surface water in the basin as it relates to agricultural production and outdoor recreation. Given the complex interactions between surface water management on public and private land, and the various goods and services that are derived from adequate water resources, an economic assessment of surface water management will assist future decision making in the basin. For example, the Harney Basin Wetlands Initiative (HBWI) and the Harney County Watershed Council and Harney County Court's community-based water planning effort will benefit from the economic assessment of surface water management in the basin. The variable basin surface water supply, and the HBWI objectives of improving aquatic health and maintaining wet meadow habitat, necessitate an assessment that identifies economic outcomes and opportunities to balance water use for pasture, outdoor recreation, and conservation.

This effort will characterize the economic benefits and regional economic contribution of activities that are directly or indirectly related to the allocation and use of surface water in the basin, focusing on agricultural production and outdoor recreation. We characterize the economic benefit derived from surface water use for these activities through several economic valuation methods. To estimate the economic benefit of surface water for irrigated pasture, we use the "residual value" method and develop crop budgets specific to the basin that estimate revenues and costs per acre for flood-irrigated pasture production. Crop budgets were developed through focus groups with local producers and data from the U.S. Department of Agriculture (USDA) National Agriculture Statistics Service (NASS, 2019). Crop budgets are combined with (1) data on the number of acre-feet of surface water consumptively used per acre, and (2) data on the number of acres of surface water-irrigated pasture from the Oregon Water Resources Department (OWRD) to estimate the total net returns to water in the basin.

To estimate the economic benefit of recreational opportunities supported by surface water we rely on the contingent valuation method (CVM) and the benefit transfer method (BTM) to estimate the economic benefits, or consumer surplus, associated with outdoor recreation at the MNWR. Bird viewing visitation data are combined with estimates of consumer surplus obtained from a mail-back visitor-intercept survey of people who visit the MNWR for bird viewing (Sexton and others, 2012a; b). To estimate the economic benefit of upstream habitat for native fish supported by surface water, recreational fishing visitation data from MNWR and the Bureau of Land Management (BLM) are combined with benefit estimates for freshwater fishing drawn from Oregon State University's Recreation Use Values Database (RUVD) (Oregon State University, 2016).

The jobs and business activity supported by agricultural production and recreation related to surface water are also estimated. Building off past assessments, a regional economic model of the region surrounding MNWR is constructed using IMPLAN modeling software (IMPLAN Group LLC., 2018). IMPLAN is a computerized database and modeling system that provides a regional input-output analysis of economic activity. Regional economic contributions from flood-irrigated pasture are estimated by applying the total available animal unit months (AUMs) of flood-irrigated forage to coefficients from the BLM that estimate economic activity supported per 1,000 AUMs in the State of Oregon. These coefficients were developed using Census of Agriculture (COA) data and IMPLAN models. Economic contributions from total spending from bird viewers and anglers are estimated by combining annual visitation data with spending profiles developed by the U.S. Fish and Wildlife Service (FWS) (Caudill and Carver, 2019). Total spending includes spending made by local visitors (those who live within 50 miles of MNWR) and non-local visitors (those who live more than 50 miles from MNWR). The spending profiles are activity-specific to bird viewing and fishing and help account for differences in per person, per day spending patterns across the categories of lodging, food and drink, transportation, and other expenses. We estimate contributions for Harney County and the surrounding region, in this case the State of Oregon.

A synthesis of the above findings will allow for the development of a conceptual framework to represent the tradeoffs that present themselves when scenarios change surface water allocation and use in the basin (for example, through different management or hydrologic scenarios). This approach will facilitate the community-based water planning objective to balance water use and make informed water resource management decisions by identifying tradeoffs between competing demands for surface water and the economic importance of altered surface water management policies. Also discussed are example conservation programs that may be able to fund conservation efforts on public and private land by capturing the economic benefit of recreation or fish and wildlife conservation through voluntary contributions or regional or State fees or taxes. For example, maintaining wet meadow habitat at recommended levels may involve tradeoffs between surface water use and instream conservation and recreation. These outcomes have effects on the economy of Harney County, including costs associated with wildlife viewing and other recreational activities as well as agricultural production. Identifying wet meadow habitat levels (considering the interconnected spatial and temporal aspects of conservation) that balance irrigated pasture and recreational economic outcomes is an important aspect of surface water management for the basin.

\section{Harney Basin}

In the next two sections we briefly review the availability of surface water in the Harney Basin and the demographic statistics of Harney County. Understanding access to surface water, both quantity and timing, and the underlying social structure that relies on access to surface water is important in an economic assessment. 


\section{Surface Water in the Harney Basin}

This section provides a brief overview of surface water resources in the basin. The OWRD segments the Harney Basin into four water availability basins (hereafter subbasins). The drainage-area-based subbasins include the Donner und Blitzen, Malheur Lakes, Silver, and Silvies. The four subbasins provide a foundation for estimating surface water availability and flood-irrigated pasture consumptive use in the basin.

\section{Water Availability Subbasins}

Water availability is a comparison of natural streamflow and consumptive uses within an individual basin. The OWRD estimates monthly natural streamflow at the 50- and 80 -percent exceedance levels. For our assessment, we use the 50-percent exceedance (average) to estimate the aggregate economic activity associated with flood-irrigated pasture.

The four water availability subbasins in the Harney Basin exhibit similar timing in monthly streamflow (fig. 2). The streamflow in the Malheur Lakes subbasin peaks in March, in April for the Silver and Silvies subbasins, and in May for the Donner und Blitzen subbasin. The Silvies subbasin contains the highest annual volume at 50-percent exceedance, almost twice as much as the other subbasins (fig. 2).

\section{Donner und Blitzen Subbasin}

The Donner und Blitzen subbasin flows from south to north in the basin through the MNWR (fig. 3). The subbasin's monthly streamflow peaks later in spring given the higher elevation headwaters in Steens Mountain. The upper Donner und Blitzen River, near Page Springs, is the location of most fishing for redband trout in the basin.

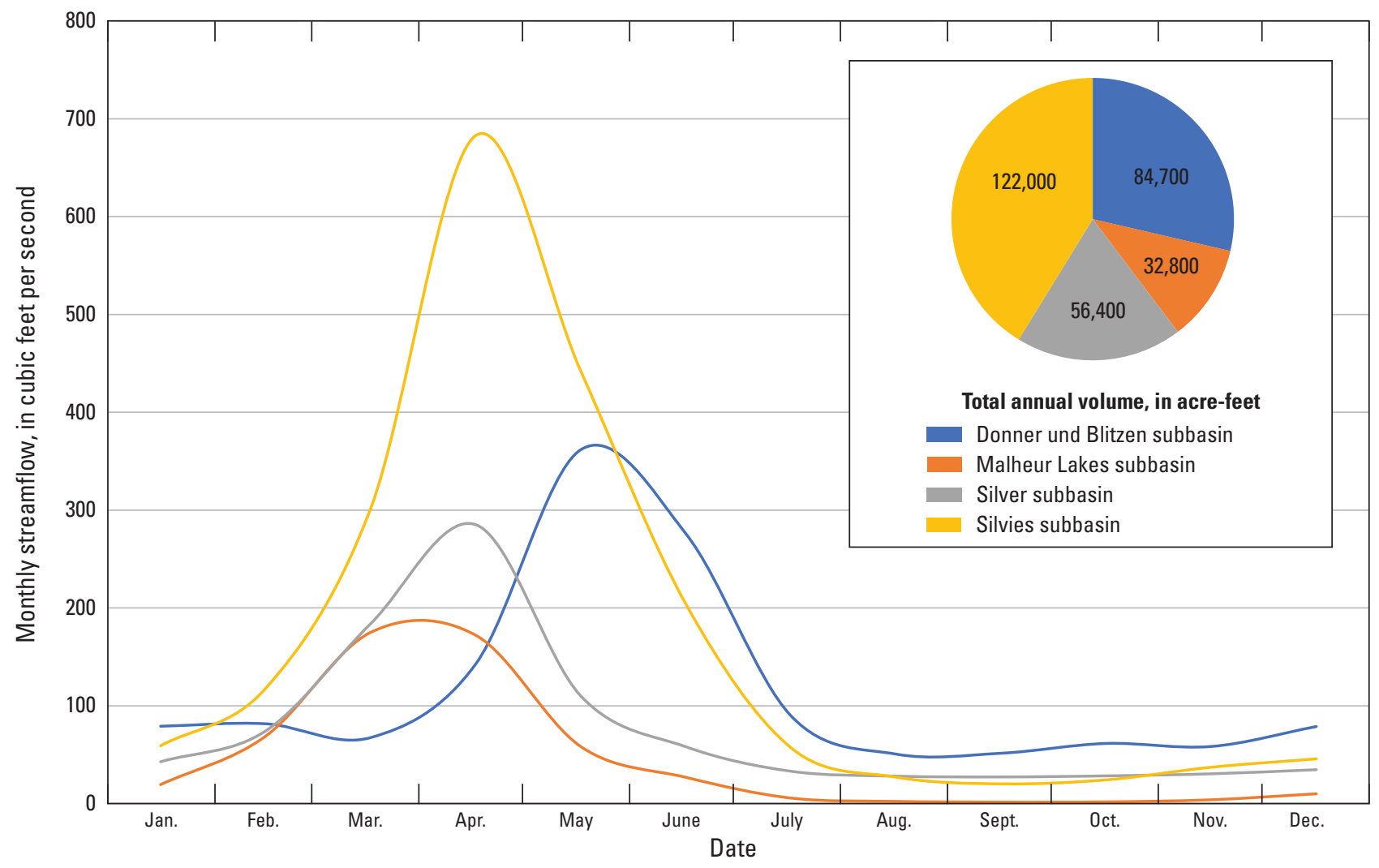

Figure 2. Monthly streamflow and annual volume of Oregon Department of Water Resources water availability subbasins at the 50-percent exceedance level. 


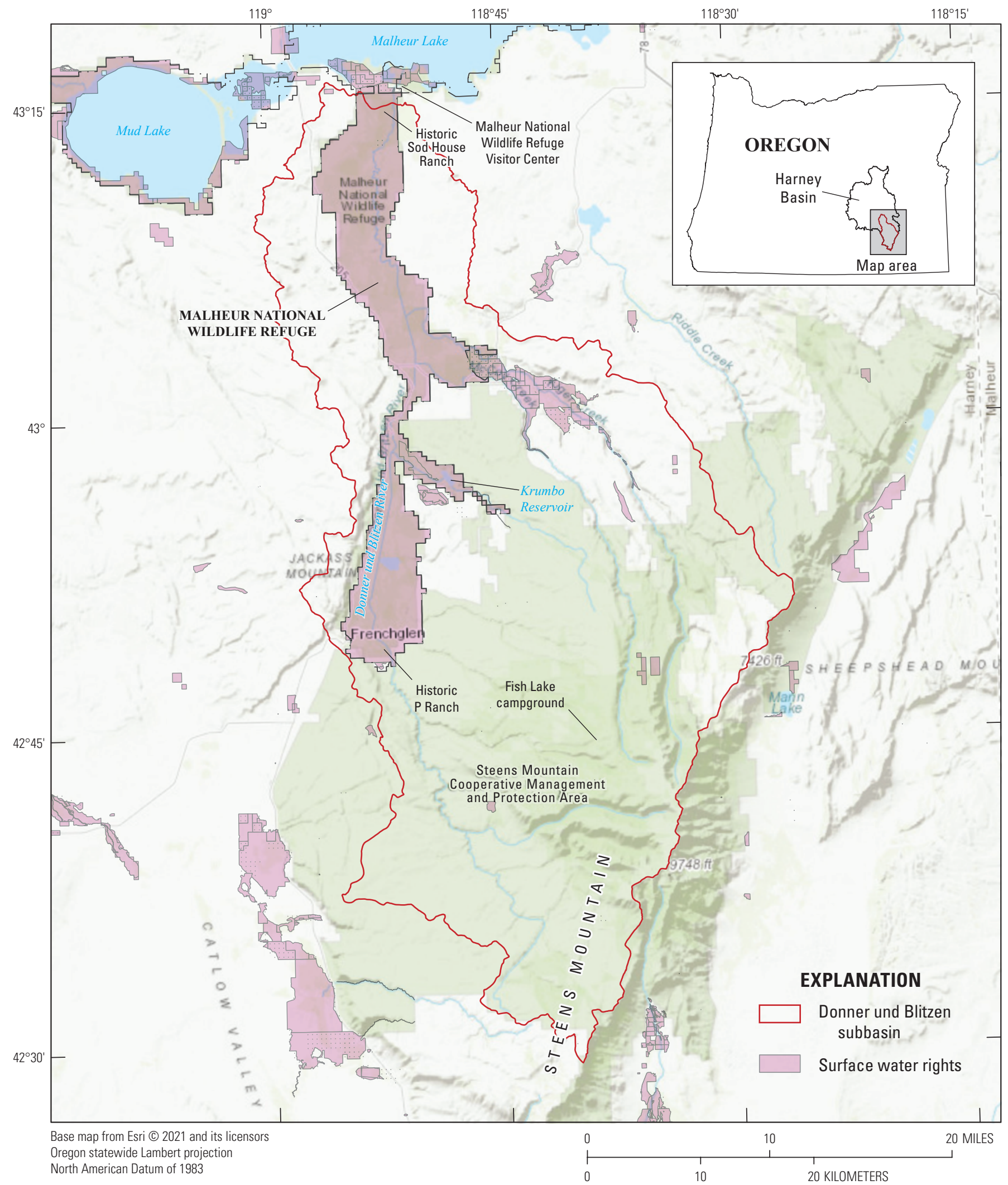

Figure 3. Map of Donner und Blitzen subbasin. Surface water rights are place of use. 


\section{Malheur Lakes Subbasin}

The Malheur Lakes subbasin is made up of a series of small streams that drain higher elevation lands located to the north of Malheur Lake (fig. 4). The streamflow in these waterbodies peaks earlier in the year than other subbasins and drains into Malheur Slough before reaching Malheur Lake. The Malheur Lakes subbasin has the smallest total annual streamflow volume in the basin.

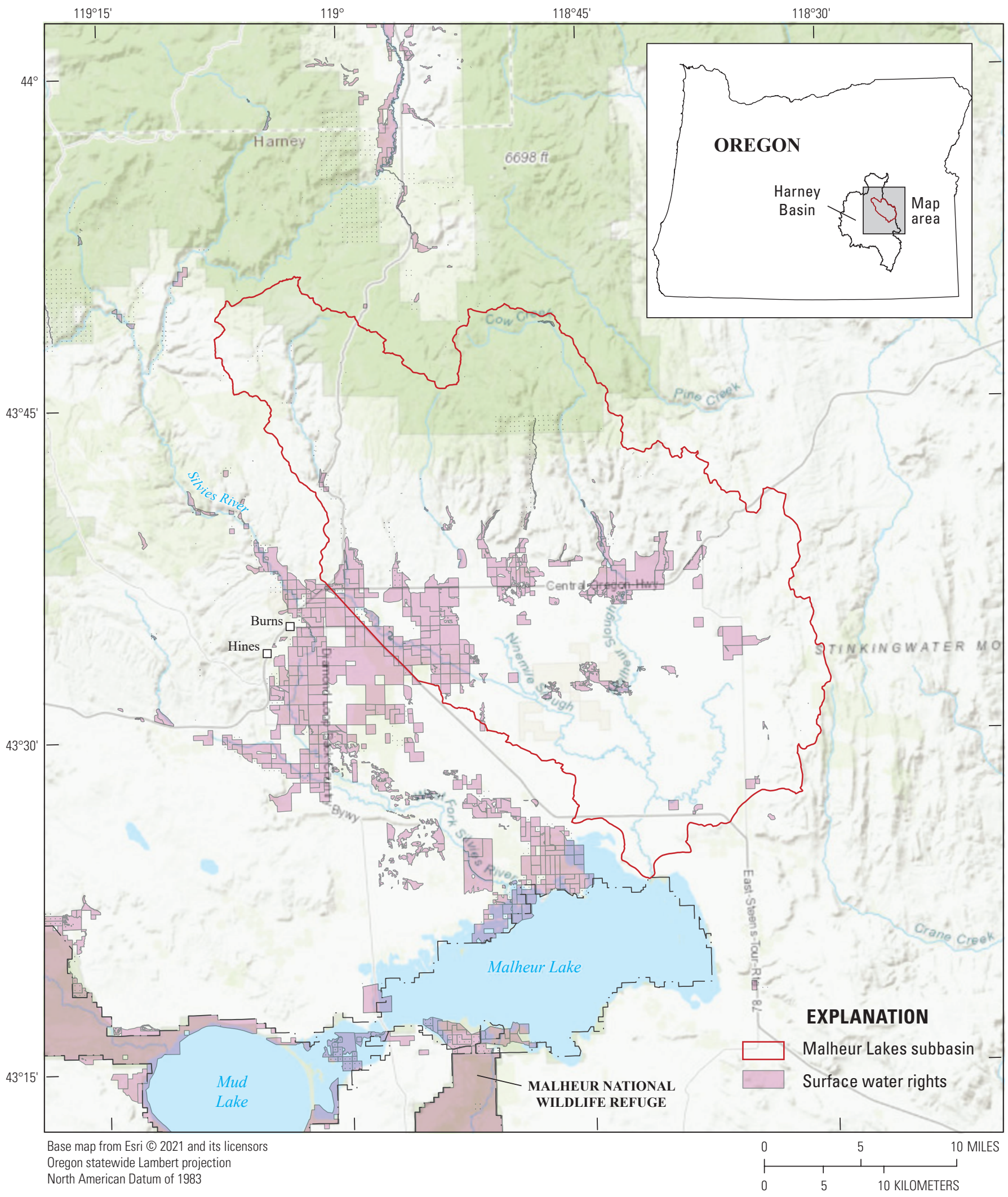

Figure 4. Map of Malheur Lakes subbasin. Surface water rights are place of use. 


\section{Silver Subbasin}

The Silver subbasin is the western most drainage in the basin and is the third smallest subbasin by annual streamflow volume (fig. 5). Silver Creek drains into Mud Lake during years with adequate streamflow. There are springs at the base of the escarpment to the south of Mud Lake. While these springs do provide surface water for wet meadow habitat and some flood-irrigated pasture, they are not included in the OWRD water availability calculations, and changes in surface water management would not likely impact spring volume in the short-run. Therefore, they are not included in the economic assessment of surface water in this report.

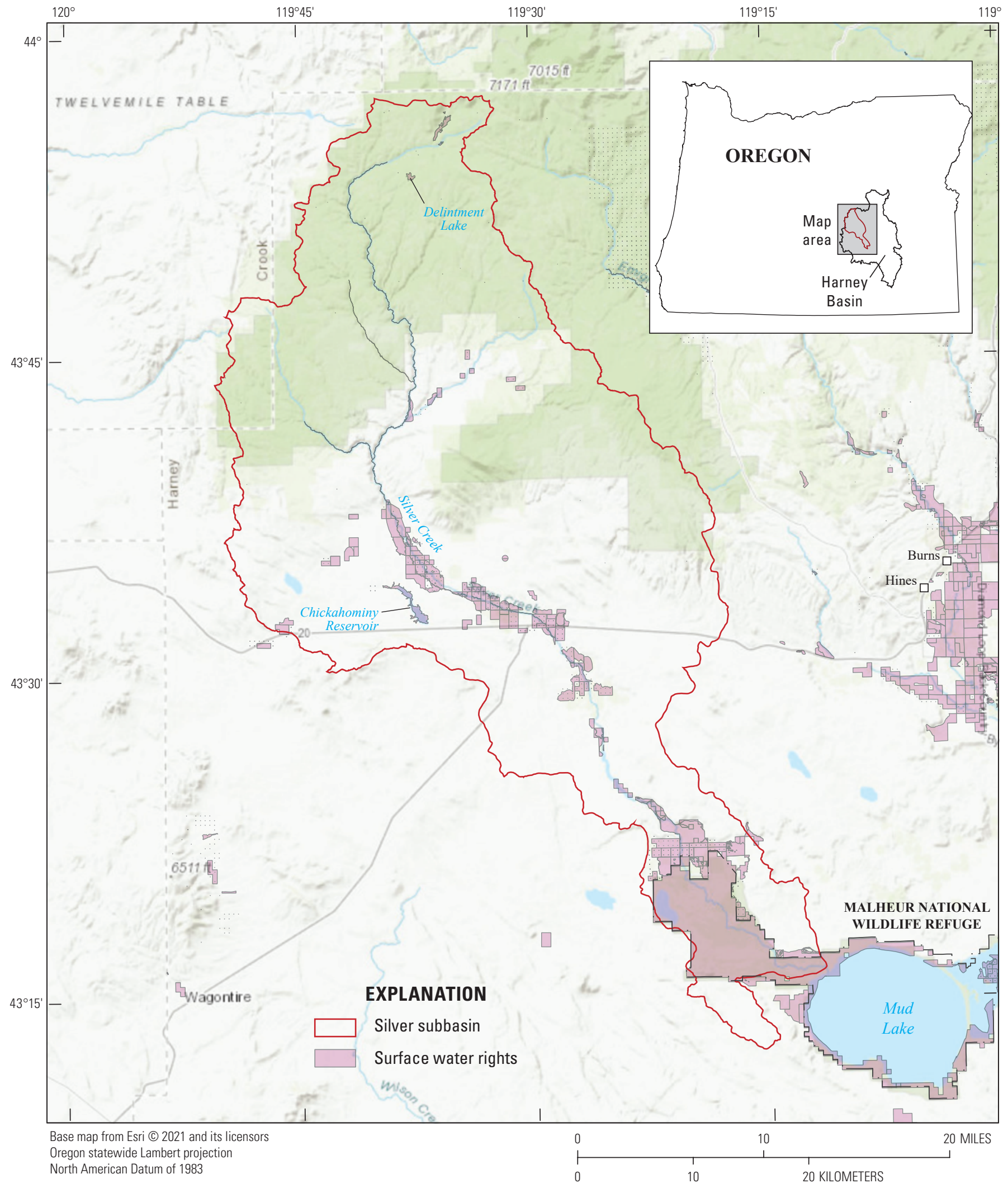

Figure 5. Map of Silver subbasin. Surface water rights are place of use. 


\section{Silvies Subbasin}

The Silvies subbasin is located to the north of Malheur Lakes and includes the municipalities of Burns and Hines (fig. 6). The Silvies is the largest subbasin in the basin by total annual volume. The majority of flood-irrigated pasture in this subbasin is on private land. Peak streamflow is in April, similar to the Silver subbasin.

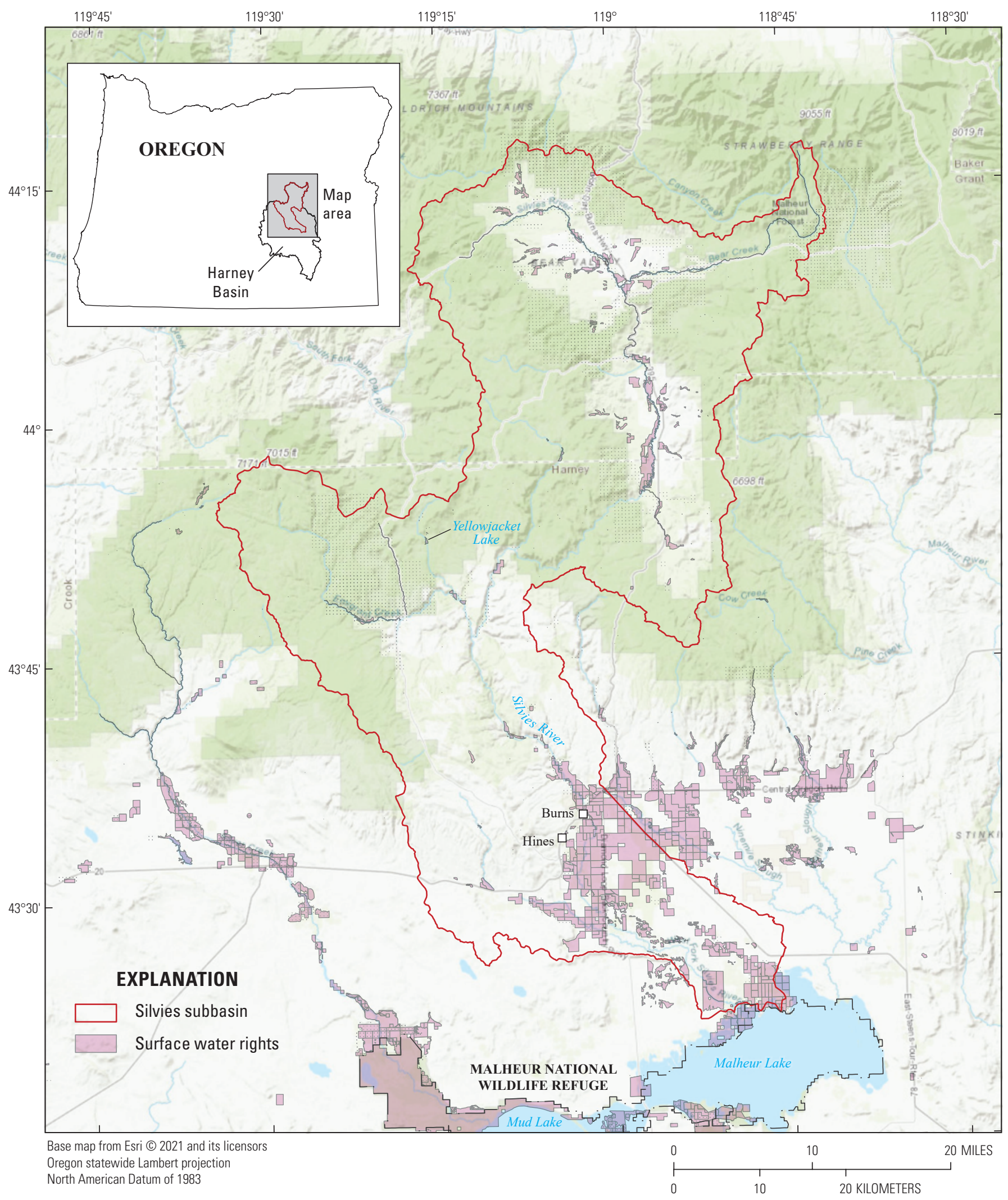

Figure 6. Map of Silvies subbasin. Surface water rights are place of use. 


\section{Demographics of Harney County}

The demographic characteristics of Harney County are important when estimating the economic benefits and contributions of surface water management. While population, education, income and employment are not directly used in our economic assessment of surface water, we do report this information for reference. A summary of demographic statistics is included in appendix 1.

\section{Economics of Surface Water}

Surface water management affects the availability, timing, and quality of water. This is especially relevant in the Western United States where water is a scarce and highly managed resource. From an economic perspective, understanding the benefits of surface water and the economic activity it supports is important for resource managers, agricultural producers, and public land agencies, including the BLM and the FWS. This is especially true for MNWR staff, whose objective is to manage the MNWR for habitat for fish, migratory birds, and other wildlife. There are two distinct ways to evaluate the economic importance of water in the basin. The first distinct economic measure is the economic benefit of water, which measures the social welfare generated by water for a particular purpose (Young and Loomis, 2014). The second measure is the importance of surface water to the region through the lens of economic contribution analysis. This type of analysis estimates the jobs and economic activity supported by expenditures in an economy (Cullinane Thomas and others, 2019; Huber and others, 2019; Loomis, 2002). As detailed later in the report, expenditures made locally by outdoor recreationists and agricultural producers support jobs and business activities within the regional economy.

\section{Economic Valuation Methods}

Economic efficiency criteria can provide a useful framework for evaluating the effects from changes in water availability for two reasons: (1) maximizing net economic benefits to society is an important objective in a world of scarcity and competing uses, and (2) it provides a useful way to evaluate the opportunity costs of competing projects or objectives (Young and Loomis, 2014, p. 25). Economists define "benefits" or "value" in terms of the tradeoff individuals are willing to make among alternatives (Segerson, 2017). Economic theory dictates that the policy-relevant case is at the margin (in other words, at a point of an incremental unit of water) and that the economically efficient outcome of water allocation occurs when marginal benefits are equal across all uses (Gibbons, 1986). Measuring these marginal tradeoffs in monetary terms is can be useful when comparing across water uses (Habb and McConnell, 2002), but doing so can be challenging when a market is either distorted or nonexistent for water uses that are considered public goods.
Quantifying the marginal economic benefit of water requires consideration of the hydrological and physical attributes, social attributes, and legal institutions, as well as the characteristics of demand for water (see Young and Loomis [2014] for a complete discussion). Demand for water includes identifying (1) water users, (2) purposes of water use, and (3) whether the use is considered consumptive or nonconsumptive. A typology for defining water demand is to differentiate between those that are offstream uses from those that are considered instream uses. For surface water, offstream uses are defined as those that are withdrawn or diverted from sources for municipal, industrial, and agricultural purposes (Dieter and others, 2018). Offstream uses are often private goods and can be classified either by the amount of water withdrawn from the water source or by the amount consumed and not returned to the source (Gibbons, 1986; Maupen and others, 2014). In contrast, instream use is defined as water that is used, but not withdrawn, from surface water sources for habitat for aquatic species, outdoor recreation, power generation, and navigation (Dieter and others, 2018). Since these instream uses do not physically remove water from the basin and allow water to be available downstream for other uses, they are considered nonconsumptive goods and services (Young and Loomis, 2014). Instream water uses are typically considered nonrival, a concept meaning that one person's use does not diminish others' ability for other uses downstream. This is in contrast with consumptive water use which is characterized as being rival. This means that one person's "upstream" use takes away a "downstream" user's ability to use the water for other purposes. Instream water uses are also often nonexcludable, meaning it is not possible to restrict others' access and use, and are thus considered to be public goods.

Another important distinction with water use is how it can serve as either an intermediate or final good (Gibbons, 1986). Water is considered a final good when directly used by consumers, such as for drinking, bathing, or other household needs. In contrast, water is considered an intermediate good when used to produce other goods or services. As an example, water used in flood-irrigated pasture serves as an input to produce hay for livestock. This distinction is important because when water serves as a final good (drinking water), it is valued directly by the consumer; as an intermediate good, value is ultimately derived from the production of final goods or services such as hay or other crops (Gibbons, 1986). The production of fish and migratory bird habitat is yet another example of how water serves as an intermediate factor in a final good valued by consumers in the form of outdoor recreation or ecosystem conservation.

For the economic benefit analyses presented here, we focus on flood-irrigated pasture production, bird viewing, and recreational fishing. Estimates of the economic benefits from irrigation were made using individual crop enterprise budgets. For bird viewing and fishing, we rely on the CVM and the BTM, respectively, to estimate the economic benefits, or consumer surplus, associated with outdoor recreation. 
Economic benefit is the maximum amount of money an individual would be willing to pay above and beyond existing costs to consume a good or service (for example, a recreational trip). These economic benefits provide a measure of the benefits to both locals and non-local MNWR visitors (Loomis and Walsh, 1997). The MNWR has no entrance fee to visitors. As is the case with many outdoor recreation opportunities on public lands, little or no price paid for an entrance fee does not indicate a lack of economic benefit. Instead, nonmarket valuation techniques must be relied upon to quantify such economic benefits (see Champ and others (2017)]). Consumer surplus is the appropriate measure for monetizing the value of nonmarket goods which can lead to the direct comparison of the full range of costs and benefits of both market and nonmarket goods and services (Brown and others, 2007). Because we focus our attention to flood-irrigated pasture production, bird viewing, and fishing, our estimate of total economic benefit of water for the basin should be viewed as a conservative estimate. Omitted from our assessment are nonuse (or passive use) values for maintaining habitat for species for future generations (bequest values) or mere viability, even if not directly used by humans (existence values).

\section{Economic Contribution Methods}

Economic contribution analysis estimates the jobs and economic activity supported by expenditures in an economy. Economic contributions are described in terms of direct, indirect, and induced effects. Direct effects occur when money first enters an economy in a direct purchase of a good or a service; for example, a bird viewer buying a meal at a local restaurant or a pair of binoculars at a local sporting goods store. In order to provide these goods and services, the directly impacted business must make their own purchases to keep their supplies stocked. These rounds of purchases are referred to as indirect effects and include the restaurant buying ground beef and buns from a grocery store or the sporting goods store purchasing a wholesale shipment of binoculars. Both direct and indirect purchases result in wages paid to employees. Wages are subsequently re-injected into the economy in the form of household purchases of goods and services, referred to as induced effects. The direct effects, resulting from an initial purchase in an economy, and the secondary effects (indirect and induced effects), generated as the initial purchase ripples throughout the economy, are estimated using input-output models (Cullinane Thomas and others, 2019; Huber and others, 2019).

IMPLAN input-output modeling software was employed in this study to estimate the economic contributions from activity related to flood-irrigated pasture and recreation in the basin and the rest of the State of Oregon. Specifically, we employed the IMPLAN Pro v3.1 2017 dataset, which describes the local economy in terms of 536 unique sectors (IMPLAN Group LLC, 2018). IMPLAN software accepts, for example, total expenditures related to bird viewing or fishing and returns contribution estimates along four metrics:
1. Jobs - the number of full and part-time jobs generated or supported by agricultural production or visitation expenditures.

2. Labor income - the employee compensation (wages/ salaries and payroll benefits) and proprietor income paid to the employees supported by agricultural production or outdoor recreation expenditures.

3. Value added - the value of production of goods and services supported by agricultural production or outdoor recreation visitation expenditures including intermediate, business-to-business purchases. Value added is equal to gross regional product, which is analogous to gross domestic product (or GDP).

4. Economic output - the total value of the production of goods and services supported by agricultural production or recreation expenditures, equal to intermediate purchases plus sales to consumers. Value added is one component of economic output.

It is important to consider and clearly define the geographic scope of the study area in a contribution analysis. The choice of study area will dictate the regional economic multipliers used by IMPLAN to translate an initial direct spending shock into secondary effects. In a traditional singleregion contribution analysis, the multipliers are determined by the availability of industries and inputs within the study area. A larger study area is more likely to include a larger diversity of industries and inputs, and therefore multipliers would likely be larger.

This study used a multi-regional input-output (MRIO) analysis to estimate the contributions from recreation visitor spending, which differs slightly from a traditional singleregion model (see Huber and others [2019] as an example). In a single-region model (for example, a single county model), if an input is not available locally, that money is "leaked" from the model and creates no additional economic contributions in the study area. In contrast, with a MRIO model, businesses in the directly impacted region (region A) (for example a single county) can make purchases from a nearby region (region B), such as other counties in the State (Clouse, 2020a). An MRIO model with a single county region $\mathrm{A}$ and rest-of-State region $\mathrm{B}$ better reflects interconnected nature of local economies than a single county model. This kind of MRIO model is also more accurate than a single-State model; although the leakage will be the same in both models, the State model's multipliers will reflect an average of all businesses in the State, whereas the MRIO's multipliers reflect the smaller region A (Clouse, 2020b).

In this study, the directly impacted region A is Harney County, Oreg. The visitor spending that makes up the direct effects occurs in the entire basin, which includes most of Harney County and slivers of Grant, Crook, and Lake Counties, Oreg. However, Harney County represents the majority of land area and population in the basin and holds the two biggest cities in the basin (Burns and Hines, Oreg.). Therefore, it is 
appropriate to use Harney County as a proxy for the basin in the IMPLAN model. Region B represents the remaining counties in Oregon. This model will show how visitor spending in Harney County supports jobs and economic activity in both Harney County and the rest of the State of Oregon.

To estimate the contributions from irrigated pasture, we used response coefficients (RCs) developed by the BLM, which were made using a traditional single State IMPLAN model for Oregon, rather than an MRIO. Although the model differs slightly from the one used for recreation expenditures, the interpretation of results is the same: flood-irrigated pasture in Harney County supports a certain number of jobs and economic activity in the State of Oregon as a whole.

\section{Flood-Irrigated Pasture}

Similar to many rural counties, one of the major economic sectors in Harney County is agriculture. Agricultural production in the county is primarily cattle and calves and hay crops (NASS, 2019). As mentioned in the description of surface water, spring snow melt fills rivers in the basin, and surface water diversions from these rivers are used to inundate flood plains for irrigated pasture production. The forage produced from these irrigated pastures is used to supplement winter feed for cow-calf operations. Without the production on flood-irrigated pasture, cow-calf operations would have to rely on off-ranch sources of forage on the open market. Flood-irrigated pasture in the basin is a combination of private and public land-land ownership is approximately 15 percent private and 85 percent public. Almost all cropland is irrigated owing to the low annual precipitation and the short growing season (Oregon Department of Agriculture, 2020). Approximately 90,000 acres of private pasture in the basin is flood irrigated in an average water year.

The public flood-irrigated pastures are primarily located on the MNWR. Flood-irrigated pastures on the MNWR were initially established in the 1870s, when uplands, marshes, and irrigated meadows were converted to provide livestock forage and expanded in the 1940s when the Civilian Conservation Corps improved the irrigation infrastructure (MNWR and FWS, 2013). Irrigated pastures on the MNWR are fundamentally similar to private meadows in that both involve applying water to land, allowing forage to grow, and cutting forage at the end of the growing season. However, meadows on the MNWR are managed with the goal of providing habitat for nesting birds and not necessarily maximizing forage output or quality. Therefore, the irrigation practices and timing differ somewhat from the privately owned irrigated pasture lands described above. Spring irrigation on the MNWR typically begins by March 15 and is maintained until early August. This timeline ensures habitat provision for breeding greater sandhill cranes, Canada geese, early nesting mallards early in the season, and crane broods later in the season. Meadows are then mowed and either rake-bunch grazed or baled and removed as hay in the late summer (MNWR and FWS, 2013; E. Sparks, oral commun., 2019). In an average water year, approximately
15,000 acres of pasture in production on the MNWR is flood irrigated (E. Sparks, oral commun., 2019). Flooded land on the MNWR exceeds the estimated flood-irrigated pasture in production. Approximately 40,000 acres total were flooded in the years between 2010 and 2016 (Donnelly and others, 2019).

\section{Flood-Irrigated Pasture Data}

There is considerable variation in the area of flood-irrigated pasture in an individual year. The flooded area is partly determined by the wintertime precipitation within the basin. To estimate the average area of irrigated pasture in each subbasin we used the total consumptive use for irrigation and consumptive use per acre reported in the Water Availability Reporting System (WARS) (OWRD, 2020). This system follows the methods outlined in Cooper (2002) to estimate natural streamflow, consumptive use and storage, and net water available, among other metrics. At a 50-percent exceedance the total annual volume of water available for surface water irrigation is approximately 165,000 acre-feet (acre-ft) (table 1). ${ }^{3}$

The estimated basin consumptive uses of surface water for irrigation can be partitioned by subbasin. The temporal aspects of surface water are consistent across subbasins, indicative of the influence of regional climate (fig. 7). The Silvies subbasin is the largest annual user of surface water for

${ }^{3}$ Exceedance is the probability that a particular value will be met or exceeded. Assuming a symmetric probability density function, a 50-percent exceedance level is equivalent to the mean value. Therefore, a 50-percent exceedance level represents an average water year.

Table 1. Consumptive water use for flood irrigation in the Harney Basin, Oreg., at the 50-percent exceedance level.

[Monthly average use in cubic feet per second $\left(\mathrm{ft}^{3} / \mathrm{s}\right)$ converted to total use by multiplying by the number of days in the month and a conversion factor of $1 \mathrm{ft}^{3} / \mathrm{s}=1.983$ acre-feet per day (https:/www.coloradoriverdistrict.org/watermeasurement/). Monthly consumptive use totals are obtained by summing the consumptive use in the four most downstream water availability basins in the Harney Basin: watershed IDs 31200101, 31200201, 31200311, 30200401 (Oregon Water Resources Department, 2020).]

\begin{tabular}{lcc}
\hline \multicolumn{1}{c}{ Month } & Average use $\left(\mathbf{f t}^{3} \mathbf{s}\right)$ & Total use (acre-ft) \\
\hline January & 0 & 0 \\
February & 0 & 4,958 \\
March & 81 & 23,243 \\
April & 391 & 61,252 \\
May & 996 & 48,026 \\
June & 807 & 16,739 \\
July & 272 & 6,780 \\
August & 110 & 3,412 \\
September & 57 & 787 \\
October & 13 & 0 \\
November & 0 & 0 \\
December & 0 & $\mathbf{1 6 5 , 1 9 7}$ \\
\hline \multicolumn{1}{c}{ Annual total } & $\mathbf{2 , 7 8}$ & \\
\hline
\end{tabular}




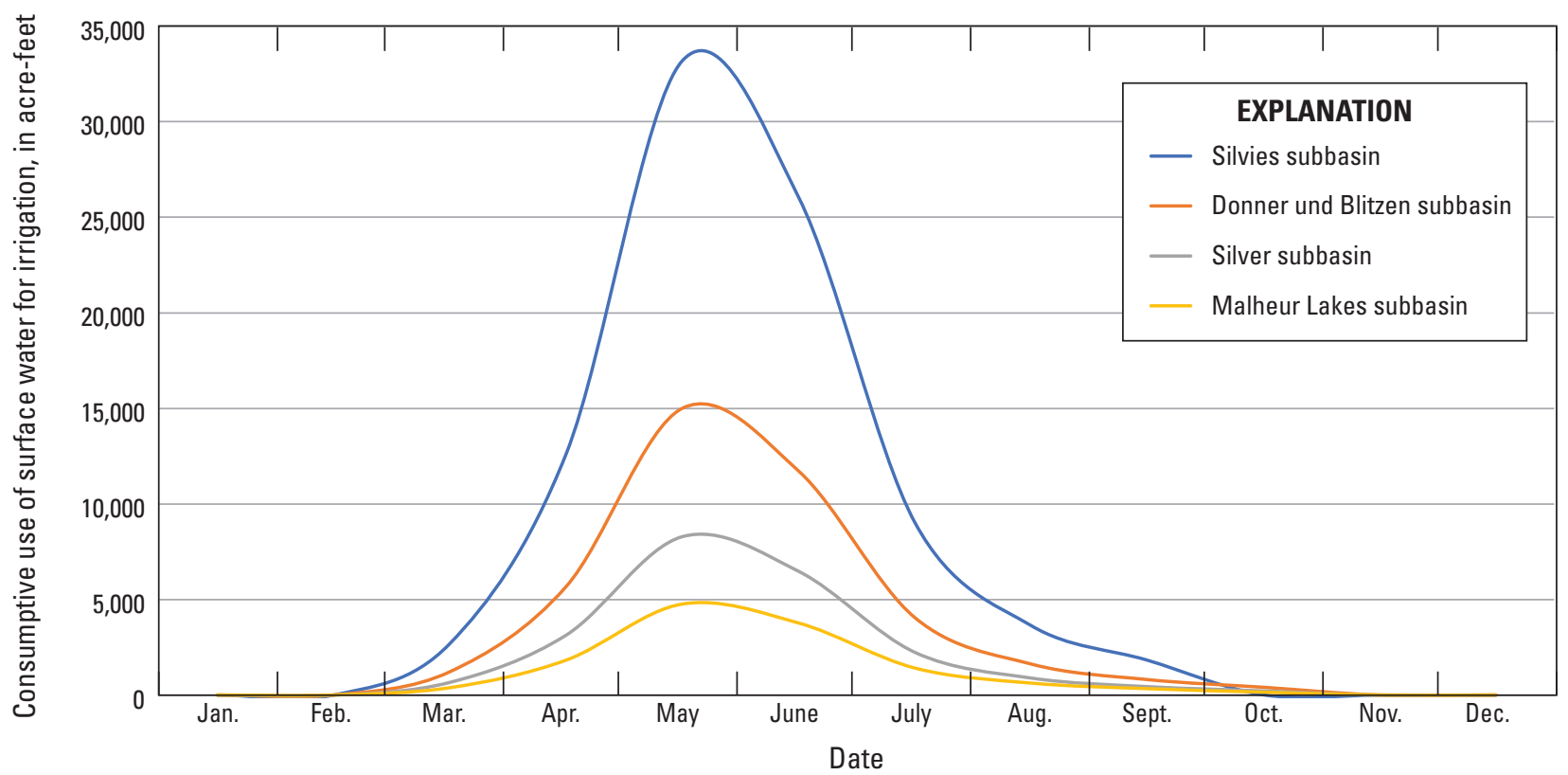

Figure 7. Surface water consumptive use for flood irrigation by subbasin at the 50 -percent exceedance level.

irrigation, a total of 89,000 acre-ft, under an average condition (fig. 7). Other subbasins collectively total 76,000 acre-ft annually (Donner und Blitzen subbasin, 41,000 acre-ft; Silver subbasin, 22,000 acre-ft; Malheur Lakes subbasin, 13,000 acre-ft).

The estimated area of flood-irrigated pasture is a function of consumptive use of surface water for flood-irrigated pasture and the consumptive use per acre. The OWRD Water Availability Reporting System (WARS) estimates monthly consumptive use and consumptive use per acre for each subbasin. This information allows for an estimated total area of flood-irrigated pasture in an average year of approximately 106,000 acres (table 2).

Additional sources of wetland flooding data were investigated to validate the original estimates. Shapefiles mapping monthly surface water flooding distributions from 1984 to

Table 2. Flood-irrigated pasture water use and area in the Harney Basin, Oreg., at the 50-percent exceedance level.

[Consumptive use and estimated consumptive use per acre at the 50-percent exceedance level are reported by the Oregon Water Resources Department (OWRD) in the Water Availability Reporting System (WARS) (OWRD, 2020)]

\begin{tabular}{lccc}
\hline \multicolumn{1}{c}{ Subbasin } & $\begin{array}{c}\text { Annual } \\
\text { consumptive } \\
\text { use (acre-ft) }\end{array}$ & $\begin{array}{c}\text { Consumptive } \\
\text { use per acre } \\
\text { (acre-ft) }\end{array}$ & $\begin{array}{c}\text { Estimated area } \\
\text { of flood-irrigated } \\
\text { pasture (acres) }\end{array}$ \\
\hline Silvies & 89,068 & 1.56 & 57,095 \\
Donner und Blitzen & 40,494 & 1.54 & 26,295 \\
Silver & 22,409 & 1.54 & 14,551 \\
Malheur Lakes & 13,227 & 1.54 & 8,589 \\
\hline $\begin{array}{l}\text { Harney Basin } \\
\text { Total }\end{array}$ & $\mathbf{1 6 5 , 1 9 7}$ & $\mathbf{1 . 5 5}$ & $\mathbf{1 0 6 , 5 3 0}$ \\
\hline
\end{tabular}

2016 were provided by the Intermountain West Joint Venture (IMWJV) (Donnelly and others, 2019). These files include information on monthly multiyear means of flooded area (for example, average flooded area in March for the period 2010 2016) within polygons defined by wetland, riparian, and agricultural boundaries. The monthly mean flooded area within the basin for the period 2010-2016 based on the IMWJV data was 92,605 acres. This includes both land within and outside of the MNWR. The total maximum flooded area within the MNWR is assumed to be equal to the highest MNWR monthly estimate, or 57,472 acres in July. Total maximum flooded area is estimated the same way outside the MNWR, using the March estimate of 35,133 acres. Note that this data includes privately owned flood-irrigated land as well as land managed by State and Federal agencies, some of which may not be flooded for agriculture purposes (for example, some public land may be flooded for habitat preservation). Regardless, these totals still provide an estimate of flood-irrigated pasture area.

To provide another estimate of flood-irrigated pasture area in the basin, the IMWJV shapefile polygons were used to download annual agricultural land cover data from the U.S. Department of Agriculture's CropScape tool (USDA NASS, 2020). Table 3 summarizes acres of flood-irrigated pasture in the basin from 2010 to 2019. Note that the pasture area from CropScape exceeds the area of surface water flooding defined by the IMWJV polygons. Only a portion of each IMWJV polygon is flooded with surface water, and the estimates reflect this portion. Due to data limitations, CropScape data was assembled using the entire polygon, not just the flooded portion. In an effort to include only surface water flooded area, the CropScape data was filtered to include only grass/pasture production, which is known to be primarily irrigated via surface water in 
the basin. However, it is possible the CropScape data in table 3 includes some area irrigated by other means (for example, groundwater), or some unirrigated dryland pasture.

Table 4 compares three estimates of flood-irrigated pasture area in the basin: OWRD consumptive use for irrigation data, IMWJV flooded area data, and CropScape grass/ pasture production area. For this study, OWRD is the preferred estimate for flood-irrigated pasture area. The information is comprised of actual water consumption use data specific to surface water irrigation, whereas the IMWJV estimate may include some area irrigated by other means. Also, the IMWJV and CropScape flood-irrigated area estimates are based on

Table 3. Average annual area of flood-irrigated pasture in the Harney Basin, Oreg., 2010-2019.

[Area totals are the sum of grass/pasture acres from CropScape (National Agricultural Statistics Service, 2020), within the area defined by the Intermountain West Joint Venture (IMWJV) shapefile polygons (Donnelly and others, 2019). Detailed assumptions and methods for the CropScape data can be reviewed on the CropScape website: https://www.nass.usda.gov/Research and_Science/Cropland/sarsfaqs2.php. The ratio of public and private floodirrigated pasture is significantly different than other sources of information (Oregon Department of Agriculture, 2020). Therefore, the CropScape data are only used as an average estimate of total flood-irrigated area in the basin and Malheur National Wildlife Refuge]

\begin{tabular}{lrrr}
\hline \multirow{2}{*}{ Year } & \multicolumn{3}{c}{ Annual area of flood-irrigated pasture (acres) } \\
& MNWR & Rest of basin & Basin total \\
\hline 2010 & 26,288 & 144,737 & $\mathbf{1 7 1 , 0 2 5}$ \\
2011 & 15,146 & 68,354 & $\mathbf{8 3 , 4 9 9}$ \\
\hline 2012 & 12,707 & 70,677 & $\mathbf{8 3 , 3 8 4}$ \\
2013 & 10,901 & 74,578 & $\mathbf{8 5 , 4 7 9}$ \\
2014 & 9,660 & 68,092 & $\mathbf{7 7 , 7 5 2}$ \\
\hline 2015 & 13,443 & 126,986 & $\mathbf{1 4 0 , 4 2 8}$ \\
\hline 2016 & 11,809 & 125,310 & $\mathbf{1 3 7 , 1 2 0}$ \\
\hline 2017 & 8,327 & 67,628 & $\mathbf{7 5 , 9 5 6}$ \\
\hline 2018 & 8,208 & 69,741 & $\mathbf{7 7 , 9 4 9}$ \\
\hline 2019 & 27,721 & 128,119 & $\mathbf{1 5 5 , 8 4 0}$ \\
\hline Average & $\mathbf{1 4 , 4 2 1}$ & $\mathbf{9 4 , 4 2 2}$ & $\mathbf{1 0 8 , 8 4 3}$ \\
\hline
\end{tabular}

Table 4. Multiple estimates of annual area of flood-irrigated pasture in the Harney Basin, Oreg.

[Oregon Water Resource Department (OWRD, 2020) estimates are based on average hydrology (50-percent exceedance). Intermountain West Joint Venture (IMWJV) (Donnelly and, others, 2019) and CropScape (National Agricultural Statistics Service, 2020) estimates are based on data that does not represent an average hydrology but historical hydrology over many years]

\begin{tabular}{lc}
\hline \multicolumn{1}{c}{ Source } & Estimated flood-irrigated area (acres) \\
\hline OWRD & 106,530 \\
IMWJV & 92,605 \\
CropScape & 108,843 \\
\hline
\end{tabular}

data that does not represent an average hydrology but recent historical hydrology. Therefore, we used the OWRD estimate of flood-irrigated pasture area in our baseline assessment.

\section{Economic Benefit of Surface Water for Flood- Irrigated Pasture}

In the basin, flood-irrigated pasture is used to produce forage for cow-calf operations and is irrigated with surface water. Flood irrigation is difficult and costly to control, thus production is dependent on natural stream hydrology (Turner and others, 1993). Haying of flood-irrigated pasture occurs in the summer following subsidence of natural streamflow and drying of pasture. Hay production on flood-irrigated pasture is an important part of cow-calf operations in the basin. This report does not detail the intricacies of cow-calf operations, but treats the forage produced on flood-irrigated pasture as an input into that process. If irrigated pasture was not used, supplemental hay would need to be purchased to support cowcalf operations.

The information contained in this report is based on a review of previous studies and publications; observations by researchers at the USDA Eastern Oregon Research Center; and discussions with people knowledgeable about the area, such as farmers and ranchers, and staff at the MNWR, High Desert Partnership, Harney County Commissioners Office, IMJWV, and other stakeholders in the basin. This data and information were gathered over two field visits in August and December of 2019 and subsequent virtual meetings. Crop production costs are based in part upon enterprise cost reports for irrigated pasture in the Western United States. Crop yields, prices received, and costs of production used in the crop budgets to estimate the return to land and water were reviewed and tailored to flood irrigation conditions based on the in-person meetings conducted in Harney County.

\section{Crop Enterprise Budgets}

Estimates of the short-run economic benefits of surface water for irrigation were made using individual crop enterprise budgets representing the anticipated economic returns and costs on a per acre basis. Annual irrigation benefits were calculated by subtracting the farm production costs from the gross farm income. Production costs include return to capital, labor, land, and management, so the net farm income represents the economic benefit of surface water for irrigation. This method is referred to as the "residual value" method. The net farm income is identified as the producer surplus, or economic benefit of water. In the basin, flood-irrigated pasture is a relatively simple production process with small amounts of production inputs (water, labor, fertilizer, and so on) and the area of production has been stable over time. Surface water in this setting represents a significant input that contributes to the value of production. Prices for all inputs have been stable over time and interviews with basin producers confirmed that all costs were being properly captured. 
Crop enterprise budgets were estimated for the four subbasins in the Harney Basin. It is assumed that similarities in topography, climate, and soil lead to costs and returns (yield and prices) that are consistent across subbasins, excluding flood-irrigated pasture on the MNWR. Irrigation practices on MNWR differ owing to the goal of habitat conservation.

There is large variation in interannual hydrology. This difference leads to significant changes in production, both in the number of acres of production and yield per acre. To account for the wide variation in hydrology, a range of yield and prices are incorporated into the crop enterprise budgets. Low-yield conditions indicate a low yield per acre and low quality of forage. High-yield conditions represents a high yield per acre and high quality of forage.

\section{Gross Return}

Gross return is based on yield and prices received on a per acre basis. While the yield associated with flood-irrigated pasture is used as an input in cow-calf operations, the gross return of forage is based on market prices in the region. Yield is an average based on historical information from basin producers and MNWR staff. Yield is dependent on annual hydrology and the site characteristics of individual parcels. For this report, the average yield per acre for the Harney Basin is used for the subbasins. To represent the broad variation that occurs in flood-irrigated pasture, we identify low-yield years and high-yield years. Yields for flood-irrigated pasture outside the MNWR range from 1 to 2 tons per acre.

Yields were adjusted for flood-irrigated pasture on MNWR. Haying of irrigated pasture on MNWR is delayed for nesting consideration for migratory birds. The delay in haying increases tonnage but reduces quality (Sneva, 1982). To account for this, the crop enterprise budget increases tonnage but decreases quality on MNWR irrigated pasture, even in high-yield conditions. The expected low and high yields on MNWR are 2.0 and 4.0 tons per acre, respectively (E. Sparks, oral commun., 2019). This is consistent with past estimates of 3.15-3.25 tons per acres (Britton and others, 1980).

Prices for forage are estimated based on conversations with ranchers in the basin and regional trends. Prices range from $\$ 100$ to $\$ 150$ per ton for low- and high-quality forage, respectively. These estimates are consistent with observed prices for all hay in the Columbia Basin from 2010 to 2019, as reported by the USDA Agricultural Marketing Service (2019). The prices for hay used in evaluating irrigation benefits should reflect the real exchange values expected over the period of analysis (U.S. Water Resources Council, 1983). The prices over the last several years represent the price relationships expected into the near future. If prices change, the expected return to an acre of flood-irrigated pasture (return to an acre foot of water) would be expected to change. To assist in implementing these guidelines, the USDA Economic Research Service (ERS) annually calculates "normalized prices" which smooth out the effects of short-run cyclical variations in prices for key agricultural inputs and outputs over the previous 5-year period. Under ordinary circumstances, these moving averages of market prices, adjusted to constant dollar values, are used by Federal agencies in evaluating the benefits from agricultural projects. The prices for all hay from the USDA ERS in Idaho, Washington, and Oregon are consistent with the estimated prices for hay from irrigated pasture (table 5) (USDA Economic Research Service, 2019). On the MNWR, the price is fixed at $\$ 80$ per ton to account for the lower forage quality.

Table 5. Regional all-hay prices (per ton) in 2019.

[Regional prices for all hay include timothy, alfalfa, and other high-quality hay. Prices represent an upper bound on high-quality flood-irrigated forage in the basin and are consistent with the $\$ 150$ per ton price used in this assessment. Data from USDA Agricultural Marketing Service, 2019; USDA Economic Research Service, 2019]

\begin{tabular}{lc}
\hline \multicolumn{1}{c}{ Region } & Hay price (per ton) \\
\hline Columbia Basin & $\$ 164$ \\
Idaho & $\$ 161$ \\
Oregon & $\$ 193$ \\
Washington & $\$ 179$ \\
\hline
\end{tabular}

\section{Variable and Fixed Cost}

Costs associated with flood-irrigated pasture vary widely. We identify production costs in low- and high-yield years. Reducing inputs (for example, fertilizer) during expected lowyield years, while increasing inputs during expected high yield years, is consistent with reported management practices. Fertilizer and herbicide costs are estimated at $\$ 45$ and $\$ 5$ per acre, respectively, during high-yield years, and $\$ 0$ during low-yield years. Cost for fertilization and herbicide treatment include chemical costs, application cost, and related labor, fuel, and machinery costs. Costs for managing flood irrigation infrastructure, repairs, supply and other miscellaneous activities do not change as annual hydrology varies (that is, these costs are consistent across low- and high-yield years). Costs for managing flood irrigation practices are assumed to be $\$ 10$ per acre, whereas other miscellaneous costs, repair, and supplies are estimated at \$20 per acre. However, dragging and aerating costs increase with yields. The costs associated with dragging and aerating range from $\$ 5$ to $\$ 8$ per acre for years with low and high yields, respectively.

Flood-irrigated pasture in the basin does not typically include costs associated with water storage facilities, pumps, conveyances, on-farm distribution systems, or sprinkler equipment. Flood-irrigated pasture in the basin is a flood-irrigated cascade, with minimal on-farm distribution systems (gates) and no pumps or sprinkler equipment. The costs related to the use of machinery and equipment in the production of floodirrigated pasture is low. Typically, the size, list price, useful life, repair costs over the useful life, depreciation costs, fuel use factor, and performance rate for machinery and equipment used in agricultural production would be considered in the construction of crop enterprise budgets. Considering the costs and returns of flood-irrigated pasture, the change in machinery 
and equipment utilization are assumed to be small relative to the overall utilization of machinery and equipment in cowcalf operations. Because of this assumption, we used expert opinion to estimate costs specific to managing flood irrigation, including custom rates. ${ }^{4}$ Other considerations such as land value, assessments and taxes, interest costs, insurance, or other miscellaneous costs are fixed costs and remain constant when evaluating the costs and returns of flood-irrigated pasture as an input into cow-calf operations, and are therefore not included in the short-run assessment.

\section{Net Return and the Economic Benefit of Water}

The assumptions concerning gross returns and production costs allow for the estimation of the economic benefit of surface water in flood-irrigated pasture production. This estimate is the economic return of flood-irrigated production, minus the cost associated with the production. The range of net return for private flood-irrigated pasture is $\$ 40$ and $\$ 162$ per acre for

${ }^{4}$ Custom rates include labor, depreciation, repairs, and return on investment. Therefore, unlike the on-farm estimates that assume no change in fixed costs (depreciation, return on investment), custom rates may be slightly higher than comparable on-farm estimates. low-yield-cost and high-yield-cost years, respectively (Silvies subbasin, table 6). The range of net returns for public floodirrigated pasture is $\$ 90$ and $\$ 157$ per acre for low-yield-cost and high-yield-cost years, respectively (MNWR and FWS, 2013; table 7).

As discussed above, the MNWR manages flood-irrigated production in different ways. The forage is cut at a later date in the growing season to provide for nesting habitat, and some areas are not cut, increasing the cost of harvest. The delay in harvest decreases the protein content in the forage, which may reduce its nutritional and economic value. The crop budget for MNWR accounts for this by increasing the tonnage in low and high production years and fixing the hay price per ton at $\$ 80$ (table 7).

The subbasins have equivalent gross returns, variable costs, fixed costs, and net returns. However, the consumptive use per acre attributed to each subbasin varies, and therefore so does the estimated irrigated pasture area (table 2). This variation leads to a different economic benefit of an acre-foot of surface water in each subbasin (table 8). Estimated returns to water represent the economic benefit to producers who do not have to purchase hay on the open market, thus representing a cost savings, or alternatively, increased profits.

Table 6. Crop budget costs and returns of flood-irrigated pasture in the Silvies subbasin, Oreg.

[Fixed costs such as general overhead, depreciation, and taxes are not included in the estimate of variable costs and returns]

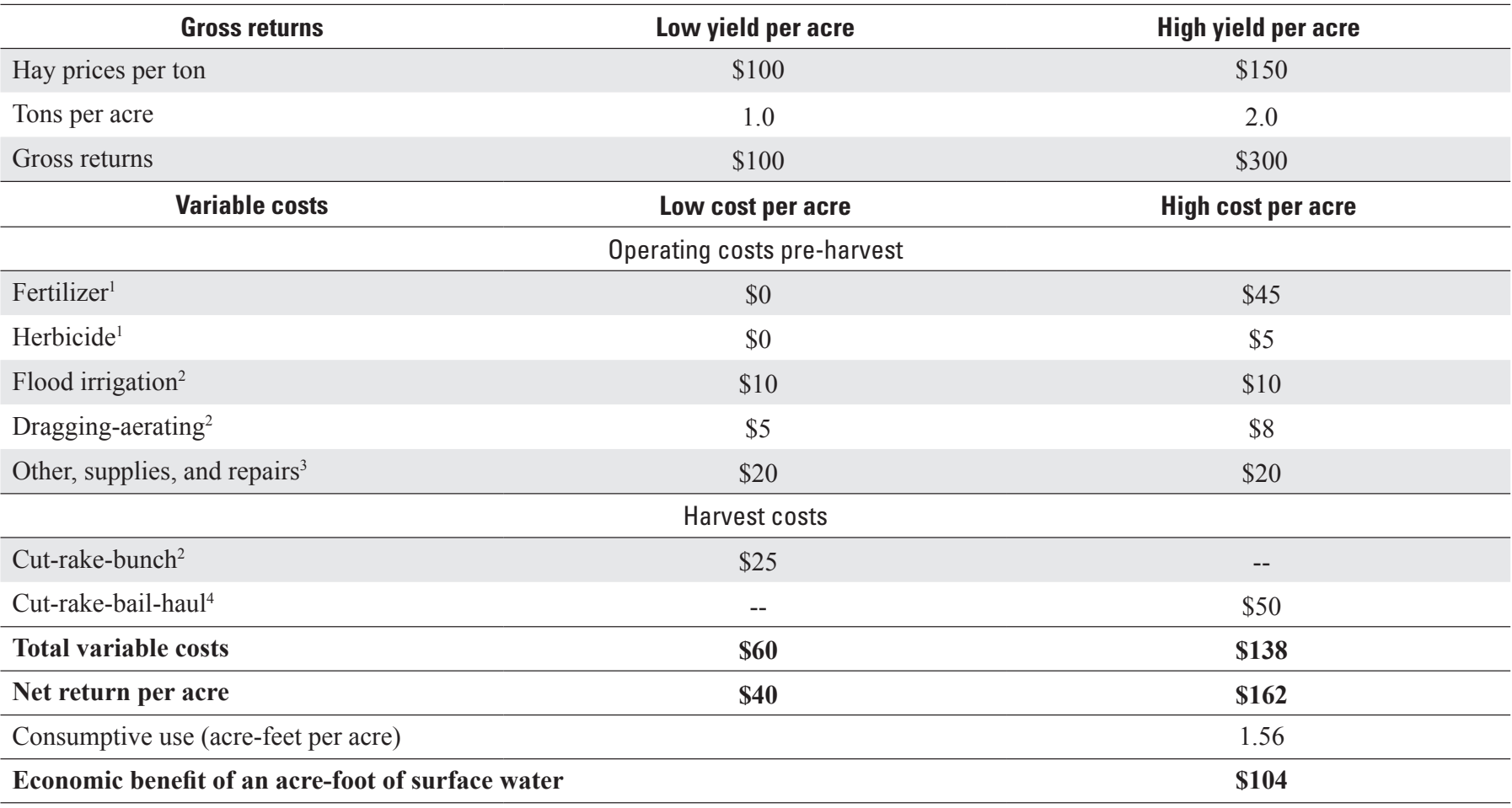

${ }^{1}$ Includes agricultural chemicals, chemical application, and required farm labor, fuel, and machinery.

${ }^{2}$ Includes required farm labor, fuel, and machinery.

${ }^{3}$ Other costs may include custom work, storage, repairs to machinery or fencing, or any other cost not listed elsewhere in the budget.

${ }^{4}$ Includes required farm labor, fuel, machinery, and transportation. 
Table 7. Crop budget costs and returns of flood-irrigated pasture in the Malheur National Wildlife Refuge, Oreg.

[Fixed costs such as general overhead, depreciation, and taxes are not included in the estimate of variable costs and returns. These estimates are derived from general production practices and yield specific to MNWR (MNWR and FWS, 2013).]

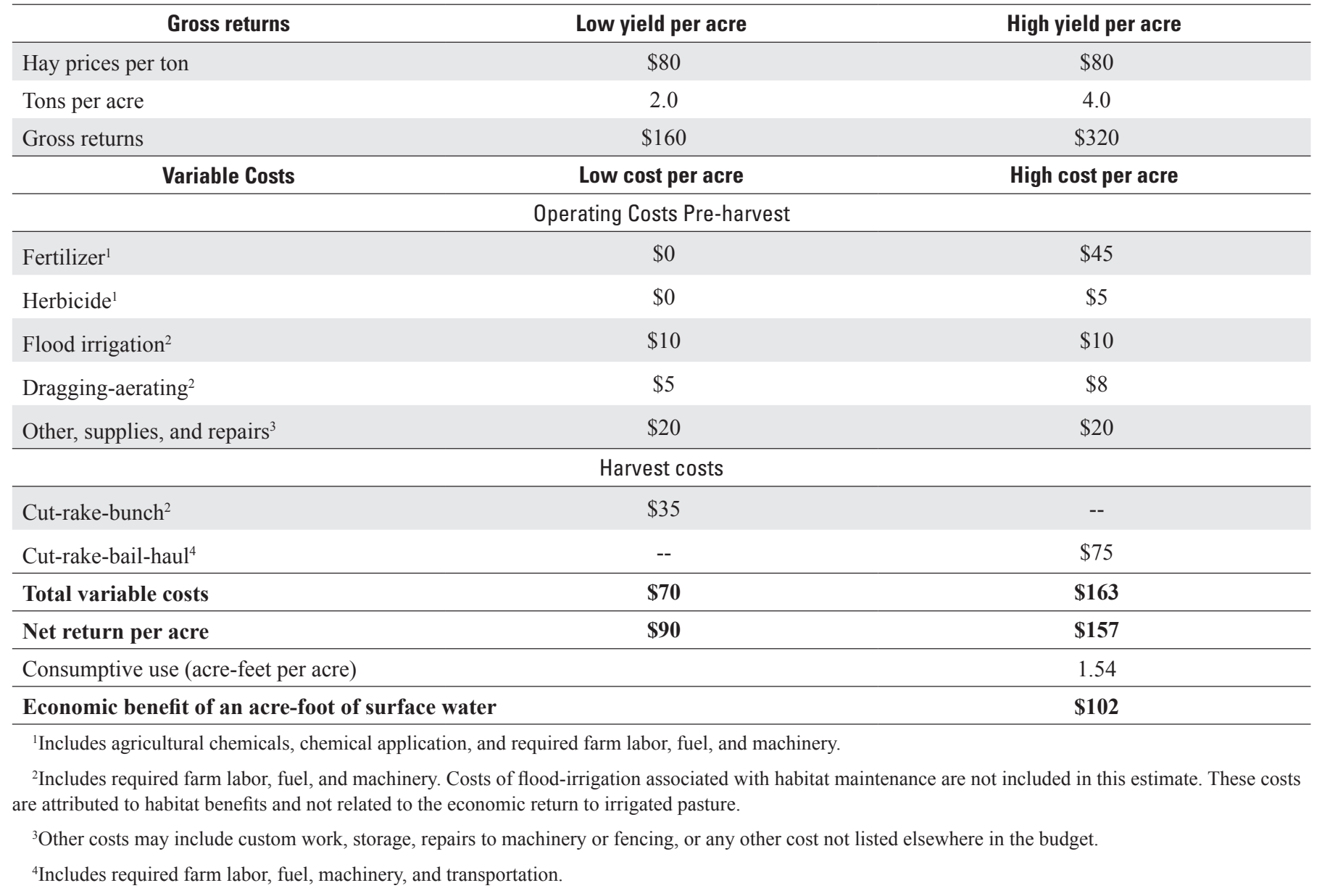

Table 8. Economic returns to flood-irrigated pasture in the Harney Basin, Oreg.

[Return per acre-foot is estimated by dividing the return per acre by the estimated consumptive use of water per acre (Oregon Water Resources Department, 2020) and based on water availability at the 50-percent exceedance level]

\begin{tabular}{|c|c|c|c|c|c|}
\hline \multirow{2}{*}{ Subbasin } & \multicolumn{2}{|c|}{ Return per acre } & \multirow{2}{*}{$\begin{array}{c}\text { Return per acre-foot } \\
\text { of water }\end{array}$} & \multirow{2}{*}{$\begin{array}{l}\text { Total volume } \\
\text { (acre-ft) }\end{array}$} & \multirow{2}{*}{$\begin{array}{l}\text { Total economic } \\
\text { return }\end{array}$} \\
\hline & Low & High & & & \\
\hline Silvies & $\$ 40$ & $\$ 162$ & $\$ 105$ & 89,068 & $\$ 9,352,140$ \\
\hline Silver & $\$ 40$ & $\$ 162$ & $\$ 104$ & 22,409 & $\$ 2,330,536$ \\
\hline Malheur Lakes & $\$ 40$ & $\$ 162$ & $\$ 104$ & 13,227 & $\$ 1,375,608$ \\
\hline
\end{tabular}




\section{Regional Economic Contribution of Flood Irrigation}

In the basin, flood irrigation is primarily used to grow pasture that is grazed by cattle, and therefore represents a major input to cow-calf operations. One method to estimate the economic contribution of surface water used for irrigation is to estimate the economic activity associated with grazing of floodirrigated pasture. This approach assumes flood irrigation makes possible a certain level of grazing, and grazing is associated with a certain level of economic activity that we can estimate.

The BLM has developed RCs that describe the Statelevel economic contributions associated with grazing. The RCs estimate the output, jobs, labor income, and value added per 1,000 AUMs of grazing available. To develop the RCs, the BLM used 2017 NASS COA (NASS, 2019) data to estimate State- and livestock-specific (for example, Oregon cattlespecific) AUM usage, farm employment, income, sales, and livestock inventory. Direct employment, labor income, and output RCs were estimated by dividing statewide economic activity (for example, statewide cattle ranching jobs) by total statewide AUM usage. Secondary RCs were estimated by modeling State- and livestock-specific COA data on farm expenditures in a State IMPLAN model (U.S. Department of the Interior Office of Policy Analysis, 2020).

To estimate the economic contribution of flood-irrigated pasture in the basin, the amount of forage produced in a year is converted to AUMs using information from Oregon State University (1 acre equals 2 AUMs) (Gomm, 1979). There is significant variation in the quantity and quality of forage produced on private and public flood-irrigated pasture in a given year. However, with a range of 1-2 tons per acre of highquality forage on private land and 2-4 tons per acre of lower quality forage on public land, we concluded that an average of 2 AUMs per acre was a reasonable baseline assumption. ${ }^{5}$ Total AUMs in the basin are then applied to the BLM's RCs per 1,000 AUMs to estimate economic contributions.

Annual economic contributions from 106,530 acres of available flood-irrigated pasture in 2020 dollars are shown in table 9.

The grazing of flood-irrigated pasture in the basin supports 718 jobs, $\$ 11.8$ million in labor income, $\$ 40.1$ million in economic output, and $\$ 22.1$ million in value added in the State of Oregon. Most of the 718 jobs supported by pasture grazing are direct effects, or jobs on the farm or pasture land. The majority of labor income, value added, and economic output effects, on the other hand, stem from secondary effects. Secondary effects include both indirect effects, or purchases made to supply the direct activity (for example hay purchases), and induced effects, or wages spent by employees in the direct and indirectly impacted sectors on groceries and other household purchases.

${ }^{5}$ One AUM is equivalent to approximately $915 \mathrm{lbs}$. of field-cured forage. We assume that at least 20 percent of the tonnage is waste. These estimates place AUMs per acre on private land between 1.7 and 3.5.
Table 9. Economic contributions associated with flood-irrigated pasture in the Harney Basin, Oreg.

\begin{tabular}{ccccc}
\hline $\begin{array}{c}\text { Economic } \\
\text { impact type }\end{array}$ & $\begin{array}{c}\text { Supporting } \\
\text { jobs }\end{array}$ & $\begin{array}{c}\text { Labor } \\
\text { income }\end{array}$ & $\begin{array}{c}\text { Economic } \\
\text { output }\end{array}$ & Value added \\
\hline Direct effect & 491 & $\$ 2,575,917$ & $\$ 15,973,225$ & $\$ 7,886,006$ \\
$\begin{array}{c}\text { Secondary } \\
\text { effect }\end{array}$ & 227 & $\$ 9,063,594$ & $\$ 24,087,223$ & $\$ 14,221,486$ \\
\hline $\begin{array}{c}\text { Total } \\
\text { effect }\end{array}$ & $\mathbf{7 1 8}$ & $\mathbf{\$ 1 1 , 6 3 9 , 5 1 1}$ & $\mathbf{\$ 4 0 , 0 6 0 , 4 4 8}$ & $\mathbf{\$ 2 2 , 1 0 7 , 4 9 2}$ \\
\hline
\end{tabular}

\section{Outdoor Recreation}

Bird viewing and recreational fishing are two important outdoor recreation activities that rely on surface water flows in the basin. Each spring, coinciding with peak runoff, the region hosts the "Harney County Migratory Bird Festival" to celebrate migratory birds that rely on the MNWR and surrounding floodirrigated pasture for stopover and nesting habitat (https://www. migratorybirdfestival.com/). Recreational fishing is popular throughout the region as well, specifically for redband trout in the Donner und Blitzen River. Bird viewing and fishing are the primary focus of this assessment because they represent outdoor recreation activities most directly affected by surface water management in the basin. While other activities such as swimming or boating and hiking or auto tours can be affected by changes in surface water flows, they are not the focus of this assessment given the limited data and indirect effect of surface water flows on many of these activities.

There are two distinct measures to evaluate the economic importance of bird viewing and recreational fishing in the basin. As discussed previously, the first measure is the net economic benefits to individual recreators themselves. This economic benefit, or consumer surplus, is measured as the maximum amount of money an individual would be willing to pay above and beyond any costs actually paid to still make the trip to the basin (Loomis and Walsh, 1997). The second measure captures the economic contributions of visitor spending on the local economy (Caudill and Carver, 2019; Cullinane Thomas and others, 2019; Loomis and Walsh, 1997; White and others, 2016). This type of analysis investigates how visitor spending in the local economy ripples or cycles throughout the State to support jobs and business activity. Both economic benefits and economic contributions measure the economic significance of outdoor recreation and both economic measures rely on similar data sources, however, each measure is distinct and cannot be combined or compared. Economic benefits measure consumer preferences for or enjoyment derived from the outdoor recreation activity, while economic contributions measure the ripple effects of people's spending within the local economy. Both economic measures require data on the number of annual visits to the basin for recreational purposes. Economic benefit estimates are collected through empirical data or surveys of individual recreationists and identifying economic contributions of recreation visitation requires additional information on visitor spending in the local economy. 


\section{Visitor Use Data}

Visitation data for the basin are drawn from the Refuge Annual Performance Plan (RAPP) (R. Roberts, written commun., 2019) and from fishing data compiled by the Oregon Department of Fish and Wildlife (ODFW, 1980). Understanding the number of people who view birds and fish on private and federally managed lands throughout the basin is an important component to quantifying economic benefits to visitors and the economic contributions from visitor spending on the local economy. There is no information collected relating to recreation on private land. However, it is assumed that very few primary purpose recreation trips are exclusive to private land and do not include trips to MNWR.

Annually reported MNWR RAPP data are guided by the 2013 MNWR Comprehensive Conservation Plan (CCP), which provided the foundational estimate of annual visitor use at MNWR (MNWR and FWS, 2013). Using a combination of vehicle and door counts from December 1, 2009, to November 20, 2010, the MNWR CCP estimated a total of 65,600 total daily visits per year in 2012 , which then translates to approximately 22,600 visitors after adjusting for length of stay (approximately 3 days according to the CCP). The average number of MNWR visitors was 25,813 per year between 2012 and 2019 after omitting 2016, owing to the MNWR closure (table 10). Using the door count data, the MNWR CCP reports that visitation slowed during the winter months and increased in the spring, peaking around mid-May (MNWR and FWS, 2013) and marking the spring arrival of migratory birds to the refuge. Additional information is needed to segment annual total visitation at the MNWR by recreation activity type; in other words, the number of visitors who participated in bird viewing and fishing at the refuge.

Table 10. Annual number of visitors to the Malheur National Wildlife Refuge, Oreg., from 2012 to 2019.

[Data from Refuge Annual Performance Plan (R. Roberts, written commun., 2019)]

\begin{tabular}{|cc}
\hline Year & Number of visitors \\
\hline 2012 & 22,600 \\
\hline 2013 & 23,730 \\
2014 & 23,967 \\
2015 & 25,418 \\
\hline 2016 & 8,000 \\
2017 & 26,956 \\
\hline 2018 & 28,304 \\
\hline 2019 & 29,719 \\
\hline Average (all years) & $\mathbf{2 3 , 5 8 6}$ \\
\hline Average (excluding 2016) ${ }^{1}$ & $\mathbf{2 5 , 8 1 3}$ \\
\hline
\end{tabular}

${ }^{1}$ Malheur National Wildlife Refuge was closed for part of 2016
Data for understanding primary purpose outdoor recreation activity at MNWR are drawn from a U.S. Geological Survey (USGS) onsite visitor survey at the MNWR by Sexton and others (2012a, 2012b). Their survey protocol and questionnaire were approved by the Office of Management and Budget (OMB control number 1018-0145; expiration date, June 30,2013). The survey was an onsite, mail-back survey following recommendations in Dillman (2007). A total of 315 visitors agreed to participate in the survey and 276 completed questionnaires for a response rate of 87.6 percent. Among the total number of participants who agreed to take the survey, 68 percent were contacted at the MNWR visitor center, 20 percent were contacted at Krumbo Reservoir, 7 percent at Historic $\mathrm{P}$ Ranch, 3 percent on the auto-tour route, and 2 percent at the Historic Sod House Ranch.

The survey asked which activity during the most-recent visit was the primary activity (fig. 8). Among survey respondents, more than 64.1 percent reported bird viewing to be their primary activity on their most-recent trip. This was followed by wildlife viewing (10.5 percent), recreational fishing (4.3 percent), and photography (4.0 percent). Auto-tour accounted for another 3.6 percent and the all other activities account for the remaining 13.4 percent. This information is used to segment the total annual number of visitors to MNWR by activity type.

Applying the percentage of primary activity types for bird viewing and fishing to the reported RAPP visitor counts for 2019 (29,719 visitors) (R. Roberts, written commun., 2019) yields total visitors by primary activity type (table 11). These activities are the primary focus of this assessment because they represent outdoor recreation activities most directly affected by surface water management on or near MNWR. We acknowledge that other activities, such as hiking or auto tours, can be

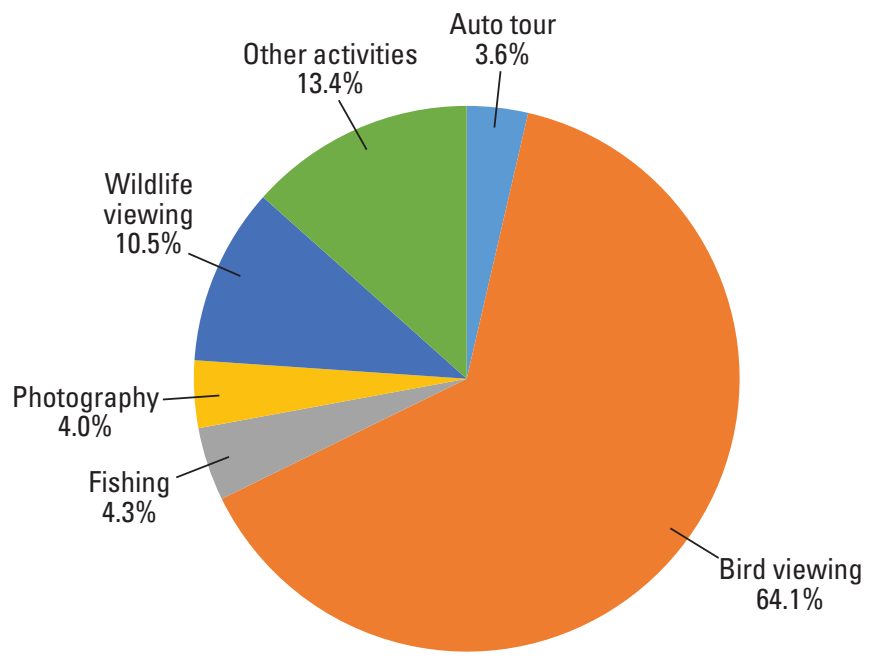

Figure 8. Percentage of primary activity types for most recent trip to Malheur National Wildlife Refuge, Oreg. Number of observations is 276. Data from Sexton and others (2012a, 2012b). 
indirectly affected by changes in surface water flows, but these are less directly affected than bird viewing and fishing, which are more reliant on surface water for wildlife habitat.

The average length of stay per visitor is used to convert the number of visitors to visitor days. Length of stay data are drawn from the Sexton and others (2012a, b) survey, which asked "How much time did you spend at this Refuge on your visit?" Respondents had the option to report the number of days or hours on their visit to MNWR. For statistical purposes, respondents who reported the number of hours (in other words, less than an overnight visit) were recoded as a 1-day trip. Across all primary activities, the average length of stay per visit is 2.59 days, which ranges from 1.27 days for fishing to 2.88 days for bird viewing (table 11). After accounting for length of stay per visitor, the number of days by activity is 1,642 days for fishing and 54,889 days for bird viewing. We assume that the 54,889 days bird viewing is a close approximation to total days bird viewing throughout the basin. While this is a conservative estimate, since it does not include private lands and other public lands, we believe most bird viewers will visit MNWR at some point during their visit to the basin.

Other federally managed public lands within the basin also offer fishing opportunities not captured in MNWR visitation statics. To arrive at a more complete calculation for the basin, we explored available data from the BLM and the USDA Forest Service (FS). BLM units within the basin include the Andrews Resource Area, the Three Rivers Resource Area, and the Steens Mountain Cooperative Management and Protection Area. The FS manages the Malheur National Forest in the basin.

BLM annual visitation data are available from the internal Recreation Management Information System. However, BLM primary recreation activity data are not available, which limits our ability to count the number of visitors who view birds and recreationally fish. Annual visitation data for the Malheur National Forest are available from the FS National Visitor Use Monitoring (NVUM) survey, which is designed to better understand people's satisfaction and use of national forests (FS, 2019). The challenge with these data is that the NVUM reports visitation across the entire Malheur National Forest. Only a portion of the Malheur National Forest encompasses the upper reaches of the Silvies subbasin, but most of

Table 11. Number of visitors, length of stay, and number of days fishing and bird viewing in the Malheur National Wildlife Refuge, Oreg.

\begin{tabular}{lccc}
\hline \multicolumn{1}{c}{ Activity } & $\begin{array}{c}\text { Number of } \\
\text { visitors }^{\mathbf{1}}\end{array}$ & $\begin{array}{c}\text { Length of stay } \\
\text { (days) }\end{array}$ & Visitor days \\
\hline Fishing & 1,293 & 1.27 & 1,642 \\
Bird viewing & 19,059 & 2.88 & 54,889 \\
\hline
\end{tabular}

${ }^{1}$ Data from U.S. Fish and Wildlife Service (2019)

${ }^{2}$ Data from Sexton and others (2012a) the Malheur National Forest lies outside of the basin in Grant County, Oreg., and the NVUM data do not report on visitation at the site-specific scale necessary to estimate bird viewing or fishing visitation occurring on the Malheur National Forest in the basin.

Because of these limitations with FS and BLM data, we investigated fee registration data at campgrounds near water bodies that may support water-based recreation on BLM and FS managed lands. This includes Yellowjacket Lake and Delintment Lake in the Malheur National Forest and Chickahominy Reservoir, Page Springs campground, and Fish Lake campground managed by the BLM. From 2016 to 2018, an annual average of 1,719 camping fees were collected at Yellowjacket Lake and 506 camping fees were collected at Delintment Lake (T. Cronin, personal communication, May 18, 2020). However, there are several limitations with these data. Their group size and length of stay are unknown, and we do not know how many campers participated in fishing. These data are also incomplete because they only capture overnight visitors and omit day use visitors.

To supplement, we rely on an ODFW fish management plan from 1980 for the Donner und Blitzen River system (ODFW, 1980). In it, ODFW estimated around 8,000 angler days per year near Page Springs, which includes the MNWR. Subtracting the number of angler days at the MNWR $(1,642$ days) yields an estimated 6,358 angler days within the BLM Donner und Blitzen River system not located on the MNWR.

The annual number of days fishing near Page Springs on BLM managed lands can be combined with those estimated for the MNWR. This yields a total of 8,000 days fishing and 54,889 days bird viewing (table 12).

Table 12. Total days fishing and bird viewing at the Malheur National Wildlife Refuge and Bureau of Land Management Donner und Blitzen River system near Page Springs, Oreg.

\begin{tabular}{llc}
\hline \multirow{2}{*}{ Land unit } & \multicolumn{2}{c}{ Annual number of days } \\
\cline { 2 - 3 } & Fishing & Bird viewing \\
\hline Malheur National Wildlife Refuge & 1,642 & 54,889 \\
Donner und Blitzen River system $^{1}$ & 6,358 & N/A \\
\hline Total & $\mathbf{8 , 0 0 0}$ & $\mathbf{5 4 , 8 8 9}$ \\
\hline
\end{tabular}

${ }^{1}$ Data from Oregon Department of Fish and Wildlife (1980)

\section{Recreational Bird Viewing}

There is an estimated total of 54,889 bird viewing days in the basin per year. This estimate is conservative because it only reflects bird viewing days at the MNWR and does not capture bird viewers exclusively on BLM, FS, or private lands, but we believe it closely reflects the majority of bird viewing days that occur in the basin. This estimate is used to quantify annual economic benefits to bird viewers and the economic contributions of bird viewers' expenditures on local economic activity. 


\section{Economic Benefit}

We rely on the CVM (Champ and others, 2017) to estimate the economic benefits, or consumer surplus, associated with bird viewing in the basin. Consumer surplus is the appropriate measure for monetizing the value of nonmarket goods which can lead to the direct comparison of the full range of costs and benefits of both market and nonmarket goods and services (Brown and others, 2007). Data to measure consumer surplus were collected in the onsite visitor use survey at MNWR administered by Sexton and others (2012a, 2012b) who asked survey respondents the following CVM question:

"As you know, some of the costs of travel such as gasoline, hotels, and airline tickets often increase.

If your total trip costs were to increases, what is the maximum extra amount you would pay and still visit this Refuge?"

Survey respondents were asked to select a dollar amount from a list of 11 options ranging from $\$ 0$ to $\$ 250$. This CVM question yields value responses that are based on groups or intervals and can be statistically modeled using an interval regression (Cameron and Huppert, 1989; Welsh and Poe, 1998). An appealing alternative to relying on a statistical model is to use a more conservative nonparametric approach to calculate the value of bird viewing. This approach uses a Turnbull estimator that relies on the payment card responses for survey respondents who indicated that bird viewing was their primary activity ( $\mathrm{n}=167)$ (Haab and McConnell, 2002). This approach finds a value of $\$ 128.26$ per person per trip for bird viewing. Dividing this value by the average length of stay per visit for bird viewing ( 2.88 days) yields $\$ 44.53$ per person per day. After adjusting for inflation using the Bureau of Labor Statistics Consumer Price Index Calculator, this lower bound estimate is $\$ 150.24$ per person per trip and $\$ 52.16$ per person per day for bird viewing (in 2020 dollars). This conservative estimate is the preferred value estimate for aggregating benefits to all bird viewers in the basin.

Aggregating the $\$ 52.16$ per person per day estimate to all bird viewers in the basin $(54,889$ days at the MNWR) yields a total value of $\$ 2.8$ million per year (table 13 ). This value estimate is conservative because it only reflects bird viewing days at the MNWR and does not include bird viewers on privately owned or other publicly managed lands.

Beyond the immediate economic benefits of bird viewing in the basin, the quality of migratory bird recreation opportunities outside the basin depend on the availability and quality

Table 13. Economic benefit of bird viewing at the Malheur National Wildlife Refuge, Oreg.

[Benefit in 2020 dollars]

\begin{tabular}{lclc}
\hline \multicolumn{1}{c}{ Land unit } & $\begin{array}{c}\text { Annual } \\
\text { days }\end{array}$ & $\begin{array}{c}\text { Benefit } \\
\text { per day }\end{array}$ & $\begin{array}{c}\text { Annual } \\
\text { benefit }\end{array}$ \\
\hline $\begin{array}{l}\text { Malheur National Wildlife } \\
\text { Refuge }\end{array}$ & 54,889 & $\$ 52.16$ & $\$ 2,863,010$ \\
\hline
\end{tabular}

of habitat at the MNWR and private irrigated agricultural lands used as a stopover in the species' migratory corridors. This concept has been described as a "spatial subsidy" and is defined as the migratory services in one location being subsidized by ecological conditions and processes in other locations (Bagstad and others, 2019; Haefele and others, 2019; Semmens and others, 2011). The implication is the beneficiaries who enjoy migratory birds outside of the basin along the migratory route are indirectly benefitting from the habitat and services provided within the basin. In addition to recreational uses, migratory wildlife also provides a variety of spatial subsidy benefits, including seed dispersal, pest control, and nutrient cycling (de Groot and others, 2002; Duffy, 2009).

\section{Regional Economic Contributions}

Employment and business activities are supported by recreation and tourism expenditures from bird viewing on private and public lands in the basin. An economic contribution analysis measures the gross economic activity in the economy supported by both local and non-local visitor expenditures (Cullinane Thomas and others, 2019). With this analysis, results can be interpreted as the relative importance of total visitor spending on the regional economy.

It is important to distinguish between local and non-local visitors because each group likely has different trip behaviors, characteristics, and expenditure patterns. For bird viewing, we rely on the percent splits for local and non-local non-consumptive recreation activities used in the FWS Banking on Nature report (Caudill and Carver, 2019). Following their methods, we assume 4 percent of bird viewers are local, and 96 percent are non-local. The FWS considers local visitors to be those that live within 50 miles of the MNWR. With a total of 54,889 bird viewing days at MNWR, this yields 2,196 local bird viewing days and 52,694 non-local bird viewing days (table 14).

Table 14. Annual days bird viewing at the Malheur National Wildlife Refuge, Oreg.

\begin{tabular}{llll}
\hline \multicolumn{1}{c}{ Land unit } & $\begin{array}{c}\text { Total annual } \\
\text { days }\end{array}$ & $\begin{array}{c}\text { Local } \\
\text { days }\end{array}$ & $\begin{array}{c}\text { Non-local } \\
\text { days }\end{array}$ \\
\hline $\begin{array}{l}\text { Malheur National Wildlife } \\
\text { Refuge }\end{array}$ & 54,889 & 2,196 & 52,694 \\
\hline
\end{tabular}

To estimate visitor spending, the total number of local and non-local days are combined with per-person per-day spending profiles reported by Caudill and Carver (2019) that were derived from the 2011 National Survey of Fishing, Hunting, and Wildlife Associated Recreation (U.S. Department of the Interior and others, 2018). Spending differs for local and non-local visitors across the categories of lodging, food and drink, transportation, and other expenses. For bird-viewing expenditure estimates, we used the non-consumptive wildlife recreation spending profiles developed for FWS Region 1 (which includes Oregon). Applying per-person per-day expenditures to estimates of local and non-local bird viewing days yields total expenditure estimates of $\$ 62,619$ for locals 
and \$9.1 million for non-locals (in 2018 dollars) (table 15). Expenditure estimates are then bridged to IMPLAN sectors using the IMPLAN sector scheme of Caudill and Carver (2019) (table 16).

Table 15. Expenditures for bird viewing at the Malheur National Wildlife Refuge in the Harney Basin, Oreg.

[Expenditures in 2018 dollars]

\begin{tabular}{lrrrr}
\hline $\begin{array}{c}\text { Expenditure } \\
\text { category }\end{array}$ & \multicolumn{2}{c}{$\begin{array}{c}\text { Per person, per day } \\
\text { expenditures }\end{array}$} & \multicolumn{2}{c}{ Total expenditures } \\
\hline Local & Non-local $^{1}$ & \multicolumn{1}{c}{ Local } & Non-local \\
\hline Food/drink & $\$ 9.32$ & $\$ 66.48$ & $\$ 20,466$ & $\$ 3,503,217$ \\
Other & $\$ 10.59$ & $\$ 30.13$ & $\$ 23,253$ & $\$ 1,587,657$ \\
$\quad$ transport & & & & \\
Air transport & $\$ 0$ & $\$ 27.63$ & $\$ 0$ & $\$ 1,455,946$ \\
Other & $\$ 1.08$ & $\$ 9.80$ & $\$ 2,376$ & $\$ 516,286$ \\
\hline \multicolumn{1}{c}{ Total } & $\mathbf{\$ 2 8 . 5 2}$ & $\mathbf{\$ 1 7 3 . 1 5}$ & $\mathbf{\$ 6 2 , 6 1 9}$ & $\mathbf{\$ 9 , 1 2 4 , 1 0 2}$ \\
\hline
\end{tabular}

${ }^{1}$ Data from U.S. Department of the Interior and others (2018).
Combined spending from local and non-local bird viewers in the basin totals $\$ 9.2$ million and supports 79 jobs, $\$ 2.6$ million in labor income, $\$ 6.8$ million in economic output, and $\$ 3.8$ million in value added in the State of Oregon, including both inside and outside the basin (economic contributions are in 2020 dollars) (table 17). The vast majority of these contributions occur in Harney County: 75 jobs, over \$2.4 million in labor income, over $\$ 6$ million in economic output, and over $\$ 3.4$ million in value added.

\section{Recreational Fishing}

Total annual number of days fishing at MNWR and on BLM managed lands in the Donner und Blitzen River system near Page Springs (8,000 days) are used to estimate the economic benefits to anglers and the economic contributions to local economic activity resulting from fishing expenditures. The process for estimating the economic benefits and the economic contributions from fishing expenditures follows a similar process as outlined for bird viewing in the previous section.

Table 16. Percentage of expenditures for bird viewing in Harney County, Oreg., allocated to IMPLAN sectors.

$[\%$, percent]

\begin{tabular}{llc}
\hline \multicolumn{1}{c}{ Expenditure category } & \multicolumn{1}{c}{ IMPLAN sector } & Percentage allocated to IMPLAN sector \\
\hline Lodging & Hotels and motels, including casinos & $100 \%$ \\
Food/drink & Retail_Food and beverage stores & $\begin{array}{l}\text { Residents: } 35 \% \\
\text { Nonresidents: } 65 \%\end{array}$ \\
& & Residents: $65 \%$ \\
& Full service restaurants & Nonresidents: $35 \%$
\end{tabular}

${ }^{1}$ Air transportation spending is leaked from the model because air travel packages were likely purchased outside of Harney County

Table 17. Economic contributions from total expenditures (local and non-local) for bird viewing in the Harney Basin, Oreg.

[Contributions in 2020 dollars]

\begin{tabular}{|c|c|c|c|c|}
\hline Economic impact type & Supporting jobs & Labor income & Economic output & Value added \\
\hline \multicolumn{5}{|c|}{ Harney County, Oreg. } \\
\hline Direct effect & 62 & $\$ 2,057,025$ & $\$ 4,630,140$ & $\$ 2,720,926$ \\
\hline Secondary effect & 13 & $\$ 379,229$ & $\$ 1,467,280$ & $\$ 734,822$ \\
\hline \multicolumn{5}{|c|}{ Rest of Oregon } \\
\hline Secondary effect & 4 & $\$ 249,536$ & $\$ 716,550$ & $\$ 437,000$ \\
\hline Total Effect & 79 & $\$ 2,685,790$ & $\$ 6,813,970$ & $\$ 3,892,747$ \\
\hline
\end{tabular}




\section{Economic Benefit}

Using the Sexton and others (2012a,b) payment card contingent valuation survey data, a lower bound Turnbull estimate for fishing is calculated to be $\$ 90$ per person per trip (\$70.87 per person per day after adjusting for length of stay at 1.27 days in table 11; after adjusting for inflation, the per person per day value for fishing is $\$ 83.02$ in 2020 dollars). However, owing the low number of observations for fishing $(n=11)$, the Turnbull estimates should be viewed with a level of caution. Because of this limitation with the survey data, we instead rely on the BTM to estimate consumer surplus per day fishing in the basin.

The BTM utilizes existing nonmarket valuation data from previously conducted studies and applies those benefit estimates to a new context (Johnston and others, 2015; Rosenberger and Loomis, 2017). There are four different types of benefit transfer: (1) a unit value transfer using a single estimate from the recreation site most similar to the site being valued; (2) an average value transfer of several existing estimates drawn from the literature; (3) a function transfer that applies an estimated demand or willingness to pay function from a past study to the unstudied site; and (4) a meta-regression demand or valuation equation that statistically models past valuation studies at several sites (see Johnston and others [2015] and Rosenberger and Loomis [2017] for discussions of BTMs). The ideal situation for a benefit transfer is to rely on an existing value estimate drawn from a study that was conducted in the same location (for example, the MNWR) for the same type of outdoor recreation activity (trout fishing) being examined in the new unstudied context. A measure of reliability between different benefit transfer approaches is the absolute percent transfer error (PTE), which compares the degree of difference between the transferred value estimate with a known policy value estimate (Rosenberger, 2015). Reviews of absolute PTE conducted by Rosenberger (2015) and Rosenberger and Loomis (2017) show that value transfers (both unit and average) had mean absolute PTE of 140 percent (median, 45 percent), while benefit function transfers (including meta-analyses) tend to perform better with a mean absolute PTE of 65 percent (median, 36 percent) (Rosenberger, 2015). This suggests that function transfers offer an improvement over unit or average value transfers. However, this guidance is predicated on how close a match the sites in the underlying data are to the unstudied site. For this assessment, we explore and document different benefit transfer approaches available for valuing recreational fishing at the MNWR and throughout the basin.

A meta-analysis of outdoor recreation use documented in Rosenberger and others (2017) estimates a per day fishing value to be \$71.52 (in \$2016) for FS Region 6, which includes Oregon and Washington (this value is $\$ 76.55$ per person per day in 2020 dollars after adjusting for inflation). Their predicted average values are based on a meta-analysis of pooled economic valuation studies of a variety of outdoor recreation activities across the United States and Canada over the period 1958-2015 (see the RUVD [Oregon State University, 2016] for a complete list of studies used in their meta-analysis). There are two weaknesses with using this value estimate for benefit transfer for our unstudied site. First, the type of species caught (for our purposes, trout) is not reflected in the statistical model, and second, this value generates a regional value that includes observations conducted in Washington; both limitations may increase the chance of transfer error to our unstudied site in Oregon. In an alternative fishing-specific meta-analysis, Huber and Richardson (2016) rely on the same data in the RUVD (Oregon State University, 2016). Their meta-regression model is tailored to some of the regional variation and speciesspecific variation in the data by controlling for species type (for example, bass, tuna, salmon). Their model predicts a value for "any other fishing type" outside of Alaska to be $\$ 43.68$ per person per day (in 2014 dollars) (after adjusting for inflation, this value is $\$ 46.75$ per person per day in 2020 dollars). The weakness with applying this predicted value estimate is that trout fishing is bundled with mackerel, walleye, and pike fishing as the "any other fishing type" omitted variable in the model. As such, we believe a closer match to the good being valued (trout fishing) within the market extent may represent an improvement over this meta-analysis prediction. Although people fish for species other than trout (for example, largemouth bass can be caught at Krumbo Reservoir), we focus on trout because it represents the main species of interest in this assessment.

For this assessment, we rely on benefit estimates documented in the RUVD (Oregon State University, 2016). Following best practices, the database was restricted to trout fishing in Oregon, which recovered two observations appropriate for an average unit value transfer. The first study, Aiken and La Rouche (2003), estimated a value of $\$ 40$ per person per day fishing, which translates to $\$ 57.97$ (in 2020 dollars) after adjusting for inflation using the Bureau of Labor Statistics Consumer Price Index. The second observation is drawn from a similar study, Aiken (2009), and reports an estimated value of $\$ 58$ per person per day fishing. After adjusting for inflation, this value for fishing is $\$ 73.74$ per person per day (in 2020 dollars). Taking an average of these two values yields a value of $\$ 65.85$ per person per day fishing, which is slightly lower than, but comparable to, the lower bound Turnbull estimate using the onsite survey data from Sexton and others (2012a,b). This average value is slightly lower than the estimate provided by Rosenberger and others (2017) but higher than the estimate provided by Huber and Richardson (2016).

Using the fishing value estimate of $\$ 65.85$ per person per day, we estimate an aggregate total economic benefit across all days fishing in the basin ( 8,000 days) to be $\$ 526,800$ per year (table 18). With 1,642 fishing days, the total annual value at the MNWR is $\$ 108,126$ per year, and with 6,358 days, fishing in the Donner und Blitzen River system near Page Springs on BLM land is $\$ 418,674$ per year. 
Table 18. Economic benefits of recreational fishing at the Malheur National Wildlife Refuge and Bureau of Land Management Donner und Blitzen River system near Page Springs, Oreg.

[Benefits in 2020 dollars]

\begin{tabular}{lccc}
\hline \multicolumn{1}{c}{ Land unit } & $\begin{array}{c}\text { Annual } \\
\text { days }\end{array}$ & $\begin{array}{c}\text { Benefit } \\
\text { per day }\end{array}$ & $\begin{array}{c}\text { Annual } \\
\text { benefit }\end{array}$ \\
\hline $\begin{array}{l}\text { Malheur National Wildlife } \\
\text { Refuge }\end{array}$ & 1,642 & $\$ 65.85$ & $\$ 108,126$ \\
$\begin{array}{l}\text { Donner und Blitzen River system } \\
\text { Total }\end{array}$ & 6,358 & $\$ 65.85$ & $\$ 418,674$ \\
\hline
\end{tabular}

\section{Regional Economic Contributions}

Consistent with bird viewing documented in the previous section, we apply percent splits for local and non-local participation for fishing used by Caudill and Carver (2019). Here, we assume 50 percent of anglers are local and 50 percent are non-local. With a total of 8,000 days fishing in the basin, this yields 4,000 local angler days and 4,000 non-local angler days (table 19).

Total fishing expenditures are estimated in the same manner as described for bird viewing above, using the spending profiles of Caudill and Carver (2019) that were derived from the 2011 National Survey of Fishing, Hunting, and Wildlife Associated Recreation (U.S. Department of the Interior and others, 2018). We used the fishing spending profiles developed for FWS Region 1 (which includes Oregon). Applying perperson per-day spending totals to our estimated local and non-local fishing days yields total expenditures of $\$ 218,181$ for local visitors and \$519,111 for non-local visitors (in 2018 dollars) (table 20). Expenditure estimates are then bridged to IMPLAN sectors using the IMPLAN sector scheme developed by Caudill and Carver (2019) (see table 16)

Spending from local and non-local visitors fishing in the basin totals more than $\$ 737,292$ and annually supports six jobs, $\$ 160,000$ in labor income, $\$ 417,000$ in economic output, and $\$ 224,000$ in value added in the State of Oregon, including both inside and outside the basin (economic contributions are in 2020 dollars) (table 21). Similar to bird viewing, the vast majority of these contributions occur in Harney County-six jobs, over $\$ 151,000$ in labor income, over $\$ 392,000$ in economic output, and over $\$ 209,000$ in value added.

Table 19. Annual days recreational fishing at the Malheur National Wildlife Refuge and Bureau of Land Management Donner und Blitzen River system near Page Springs, Oreg.

\begin{tabular}{lccc}
\hline \multicolumn{1}{c}{ Land unit } & $\begin{array}{c}\text { Total annual } \\
\text { days }\end{array}$ & $\begin{array}{c}\text { Local } \\
\text { days }\end{array}$ & $\begin{array}{c}\text { Non-local } \\
\text { days }\end{array}$ \\
\hline $\begin{array}{l}\text { Malheur National Wildlife } \\
\text { Refuge }\end{array}$ & 1,642 & 821 & 821 \\
$\begin{array}{l}\text { Donner und Blitzen River } \\
\text { system }\end{array}$ & 6,358 & 3,179 & 3,179 \\
\hline Total & $\mathbf{8 , 0 0 0}$ & $\mathbf{4 , 0 0 0}$ & $\mathbf{4 , 0 0 0}$ \\
\hline
\end{tabular}

Table 20. Expenditures for recreational fishing at the Malheur National Wildlife Refuge and Bureau of Land Management Donner und Blitzen River system near Page Springs, Oreg.

[Expenditures in 2018 dollars]

\begin{tabular}{lcccc}
\hline \multirow{2}{*}{ Expenditure category } & \multicolumn{2}{c}{ Per person, per day expenditures ${ }^{1}$} & \multicolumn{2}{c}{ Total expenditures } \\
\cline { 2 - 5 } & Local & Non-local & \multicolumn{1}{c}{ Local } & Non-local \\
\hline Lodging & $\$ 3.03$ & $\$ 20.22$ & $\$ 12,139$ & $\$ 80,888$ \\
Food/drink & $\$ 11.43$ & $\$ 18.45$ & $\$ 45,713$ & $\$ 73,809$ \\
Other transport & $\$ 16.38$ & $\$ 31.63$ & $\$ 65,535$ & $\$ 126,504$ \\
Air transport & $\$ 0$ & $\$ 35.43$ & $\$ 141,716$ \\
Other & $\$ 23.70$ & $\$ 24.05$ & $\$ 94,794$ & $\$ 96,194$ \\
\hline \multicolumn{1}{c}{ Total } & $\mathbf{\$ 5 4 . 5 5}$ & $\mathbf{\$ 1 2 9 . 7 8}$ & $\mathbf{\$ 2 1 8 , 1 8 1}$ & $\mathbf{\$ 5 1 9 , 1 1 1}$ \\
\hline
\end{tabular}

${ }^{1}$ Data from Caudill and Carver (2019) and U.S. Department of the Interior and others (2018).

Table 21. Economic contributions from total expenditures (local and non-local) for fishing in the Harney Basin, Oreg. [Contributions in 2020 dollars]

\begin{tabular}{lcccc}
\hline Economic impact type & Supporting jobs & Labor income & Economic output & Value added \\
\hline Direct effect & Harney County, Oreg. & \\
Secondary effect & 1 & $\$ 127,116$ & $\$ 293,939$ & $\$ 160,593$ \\
\hline Secondary effect & 0 & Rest of Oregon & $\$ 98,713$ & $\$ 48,526$ \\
\hline Total effect & 6 & $\$ 8,376$ & $\$ 25,164$ & $\$ 15,561$ \\
\hline
\end{tabular}




\section{Indirect and Passive-Use Economic Benefits}

A total economic valuation framework can be used to identify some of the other ecosystem goods and services supported by surface water in the basin, in addition to the direct use values quantified in the flood-irrigated pasture and recreation sections. The total economic value of a resource is defined as the sum of direct, indirect, and passive-use values (Segerson, 2017). Surface water used for irrigated pasture and outdoor recreation is considered a direct use of surface water. Beyond this, there are other economic benefits in the form of indirect and passive-use values (Brown and others, 2007). Surface water in the basin indirectly supports ecosystem services that are indirectly used and benefit society, such as carbon sequestration, nutrient cycling, and pollination (Brown and others, 2007). Passive-use values that are associated with surface water use include existence values (the value in maintaining a resource regardless of actual or intended use) and bequest values (the value in maintaining a resource for the enjoyment of future generations) (Freeman, 2003).

Surface water in the basin may provide substantial ecosystem services that indirectly benefit society (Brown and others, 2007). Power (2010) describes the linkage between agriculture and ecosystem services, noting that agricultural systems supply people with food, forage, bioenergy, and pharmaceuticals, each of which are essential to human wellbeing. These systems rely on natural ecosystem services, including pollination, pest control, maintenance of soil, nutrient cycling, and water availability, and the economic benefits of these ecosystem services to agriculture may be substantial. The system also works in the opposite direction: agroecosystems can also produce and enhance a variety of ecosystem services, including soil regulation, water quality, carbon sequestration, support for biodiversity, and cultural or amenity values. Goldstein and others (2011) document a detailed list of ecosystem services generated from private rangelands, including provisioning services (such as animal protein and clean drinking water), regulating services (such as carbon sequestration and water purification), cultural services (such as outdoor recreation, maintenance of traditional lifestyles, and spiritual fulfillment), and supporting services (such as nutrient cycling and soil formation).

There are examples of the interaction between agricultural lands and ecosystem services generated on the landscape. For example, Gascoigne and others (2011) studied three ecosystem services in the Prairie Pothole Region in North and South Dakota: carbon sequestration, reduction of sedimentation, and waterfowl production. In their analysis, they compared the production and value of these services across a combination of three land use types: native grasslands, lands enrolled in conservation programs, and cropland. Other studies have applied social cost of carbon estimates to quantify the benefits of restoration projects on lands enrolled in conservation programs (Johnson and others, 2016) and grass species' ability to store carbon (Hungate and others, 2017). Hungate and others (2017) find that net carbon sequestration for the system increases at a decreasing rate in number of grass species, and thus is an example of the effects from biodiversity and species richness. In another example, Dissanayake and Ando (2014) estimate the value of ecosystem services (species richness, population density, and the presence of endangered species) from restoring a tall grass prairie in Illinois using prescribed burning practices.

In addition to past studies on selected ecosystem services provided by agricultural lands, other research has evaluated some of the nonmarket benefits from ranching beyond the perspective of profit maximization, which include amenity and lifestyle values. For example, a study in Wyoming using ranch sales transactions data found people were willing to pay a premium for working land with environmental amenities (specifically for scenic quality, elk habitat, sport fishery productivity, and proximity to town) compared to working land that lacked amenities (Bastian and others, 2002). Notably, they failed to find a significant effect from public land forage access on ranch sales, which supports the idea that lifestyle amenities may play a large role in deciding to purchase a ranch in Wyoming. In a similar study focusing on ranch sales in New Mexico and the Great Basin region, Rimbey and others (2007) examined the effect of grazing permits and forage access from public lands. They found that ranches in these two regions were overpriced relative to income earning potential from grazing permits on public land. Their findings imply that deeded and public land area effectively make a ranch bigger, and it is this added area, not the added production value from cattle grazing, that increases a ranch's value. Torell and others (2012) found similar results using ranch sales data in New Mexico and conclude that buyers are increasingly placing a value on recreation access, open space, and lifestyle amenities provided by ranches.

Based on the total economic valuation framework, people may also place an economic value on maintaining migratory bird populations in the basin regardless of whether they recreate in Harney County. According to the MNWR CCP (MNWR and FWS, 2013), several bird species listed as Federal species of concern (declining or in need of conservation) are known to exist on the refuge, including the least bittern, white-faced ibis, black tern, ferruginous hawk, burrowing owl, yellow-breasted chat, willow flycatcher, sage-grouse, mountain quail, and Lewis' woodpecker. The yellow-billed cuckoo (western population) is the only bird species federally listed as threatened that may use habitat located on or near the MNWR. From an economic perspective, many people may place a value on preserving migratory bird habitat regardless of whether they view the birds. In one example, Bowker and Stoll (1988) estimated United States households would be willing to pay $\$ 55.13$ per year to avoid the extinction of the migratory whooping crane. Others have studied the total economic value of threatened, endangered, or rare bird species, including peregrine falcon (Kotchen and Reiling, 2000), Mexican spotted owl (Loomis and Ekstrand, 1997), northern spotted owl (Rubin and others, 1991), redcockaded woodpecker (Reaves and others, 1999), and wild 
turkeys in New England (Stevens and others, 1991). Values documented in these past studies demonstrate a range of possible total economic values (direct plus passive-use values) for preserving sensitive bird species.

A similar line of logic applies to the protection of native fish in the basin. According to the MNWR CCP (MNWR and FWS, 2013), redband trout are not federally listed as endangered or threatened but are considered a species of concern (declining or in need of conservation) known to occur or are likely to occur on the MNWR. They also serve an important role as a focal species whose habitat requirements would likely support other species using the same habitat. Research has shown that total economic value for preservation of threatened, endangered, and rare wildlife species can be large but varies across species type and whether the species is considered charismatic (Richardson and Loomis, 2009). Past studies on the total economic value for preserving fish species have found a value ranging from $\$ 10$ per Wisconsin household to protect the striped shiner to $\$ 398$ per Washington household to protect saltwater fish species in western Washington and Puget Sound (in 2020 dollars) (table 22). (Additional study-level details are documented in appendix 2.) Several studies on the total economic value of freshwater fish species represent close matches to redband trout because they were conducted in Western United States river systems. For example, Layton and others (2001) estimated households in Washington are willing to pay \$269 per year to increase freshwater fish in eastern Washington and the Columbia River. Berrens and others (1996) estimated households in New Mexico are willing to pay more than $\$ 48.43$ per year to maintain minimum instream flow requirements that would protect silvery minnow habitat. The authors argue that most of this total economic value for silvery minnow is composed of passive-use values because the 3.5-inch long fish is not a desirable species for anglers. For demonstration purposes, applying the $\$ 48.43$ value per household (for silvery minnow protection in New Mexico) to all households in Harney County, Oreg. (3,157 households, appendix table 1.1), yields a value of more than $\$ 152,000$ per year. This value increases to more than $\$ 77$ million per year when aggregating to all households in Oregon (1.6 million households). Taking a conservative approach, assuming only one quarter of Oregon households place a value on maintaining Redband trout habitat yields a value of more than $\$ 19.2$ million per year. Omitted from these calculations would be values held by people living outside Oregon, and thus, arguably, represent an underestimate of the total economic value of preserving redband trout populations. These values demonstrate the potential total economic value for preserving redband trout, and although none of the species shown in table 22 represent an exact match, the evidence suggests that the economic value for their protection could be quite high when aggregating across households. Future research using household surveys to estimate willingness to pay for redband trout preservation would yield an improved estimate of aggregated total economic value.

Table 22. Economic value per household of threatened, endangered, and rare fish species.

[Value in 2020 dollars]

\begin{tabular}{|c|c|c|c|c|c|}
\hline Source & Region & Fish species & $\begin{array}{c}\text { Listed at } \\
\text { the time of } \\
\text { study }\end{array}$ & $\begin{array}{c}\text { Annual value } \\
\text { per } \\
\text { household }\end{array}$ & Type of change being valued \\
\hline \multirow[t]{7}{*}{ Bell and others (2002) } & $\begin{array}{l}\text { Coos Bay, Oreg., } \\
\text { high-income households }\end{array}$ & Salmon & Yes & $\$ 74.59$ & No longer threatened with extinction \\
\hline & $\begin{array}{l}\text { Coos Bay, Oreg., } \\
\text { low-income households }\end{array}$ & Salmon & Yes & $\$ 61.35$ & No longer threatened with extinction \\
\hline & $\begin{array}{l}\text { Grays Harbor, Wash., } \\
\text { low-income households }\end{array}$ & Salmon & No & $\$ 117.76$ & Increase in catch and run size \\
\hline & $\begin{array}{l}\text { Tillamook Bay, Oreg., } \\
\text { high-income households }\end{array}$ & Salmon & Yes & $\$ 118.33$ & No longer threatened with extinction \\
\hline & $\begin{array}{l}\text { Willapa Bay, Wash., } \\
\text { low-income households }\end{array}$ & Salmon & No & $\$ 116.58$ & Increase in catch and run size \\
\hline & $\begin{array}{l}\text { Yaquina Bay, Oreg., } \\
\text { high-income households }\end{array}$ & Salmon & Yes & $\$ 172.36$ & No longer threatened with extinction \\
\hline & $\begin{array}{l}\text { Yaquina Bay, Oreg., } \\
\text { low-income households }\end{array}$ & Salmon & Yes & $\$ 112.99$ & No longer threatened with extinction \\
\hline
\end{tabular}


Table 22. - Continued

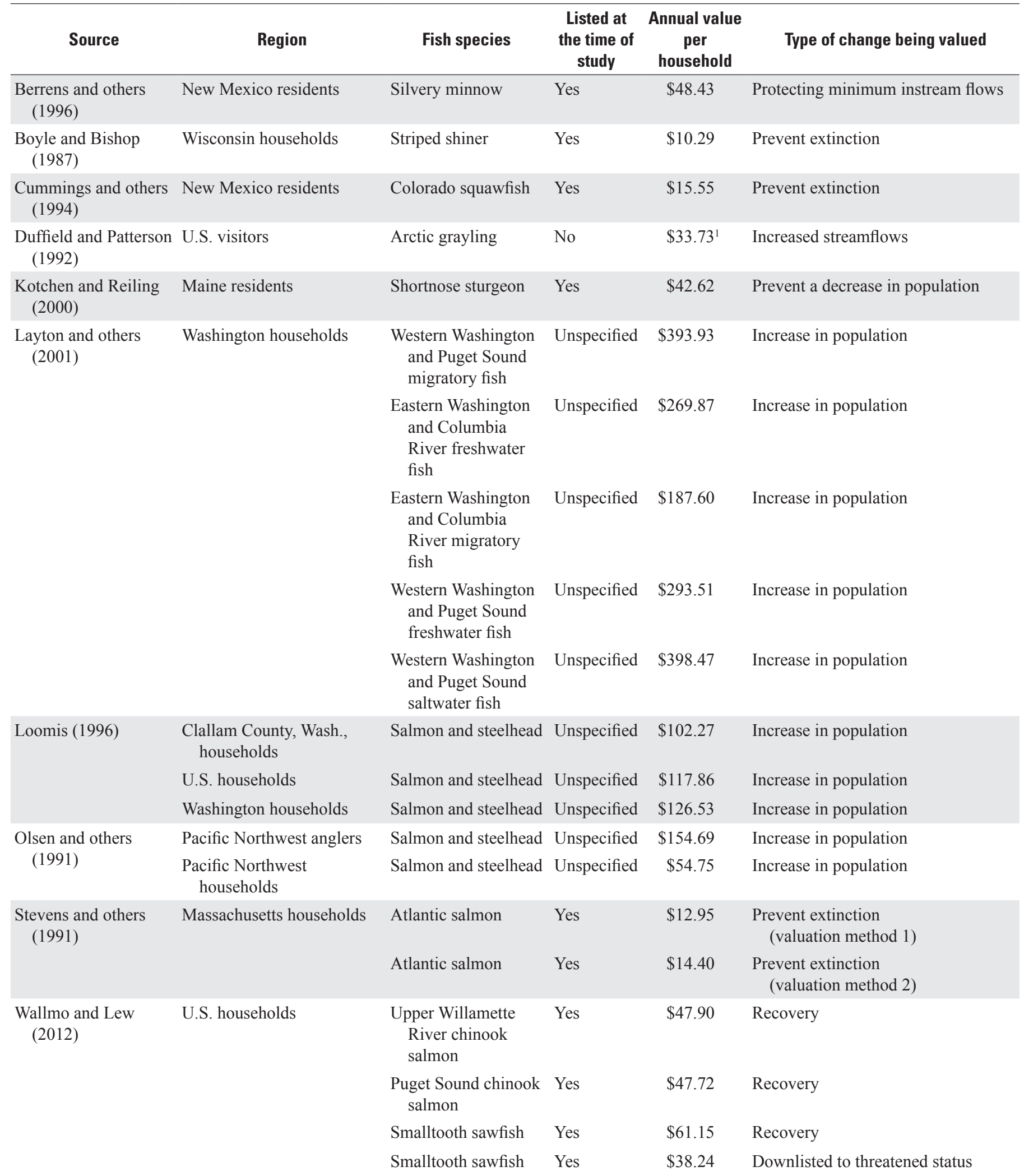


Table 22. - Continued

\begin{tabular}{|c|c|c|c|c|c|}
\hline Source & Region & Fish species & $\begin{array}{c}\text { Listed at } \\
\text { the time of } \\
\text { study }\end{array}$ & $\begin{array}{c}\text { Annual value } \\
\text { per } \\
\text { household }\end{array}$ & Type of change being valued \\
\hline \multirow[t]{3}{*}{$\begin{array}{l}\text { Wallmo and Lew } \\
\text { (2015) }\end{array}$} & U.S. households & $\begin{array}{l}\text { Central California } \\
\text { coast coho salmon }\end{array}$ & Yes & $\$ 60.17$ & Recovery \\
\hline & $\begin{array}{l}\text { California, Oregon, and } \\
\text { Washington households }\end{array}$ & $\begin{array}{l}\text { Central California } \\
\text { coast coho salmon }\end{array}$ & Yes & $\$ 68.54$ & Recovery \\
\hline & $\begin{array}{l}\text { California, Oregon, and } \\
\text { Washington households }\end{array}$ & $\begin{array}{l}\text { Southern California } \\
\text { steelhead }\end{array}$ & Yes & $\$ 91.40$ & Recovery \\
\hline
\end{tabular}

${ }^{1}$ Indicates a value per angler

\section{Summary of Direct Use Results}

Surface water use for flood-irrigated pasture and recreation in the basin has an economic benefit to society of over $\$ 20.6$ million annually (table 23). These estimates are the economic benefit, or producer and consumer surplus, of agricultural producers and recreational consumers and provide insight into the impacts of a change in surface water management and (or) opportunities to incentivize conservation.

The annual economic benefit estimates for floodirrigated pasture, recreational bird viewing, and recreational fishing represent only a fraction of the full economic benefit of working landscapes, migratory birds, and native fish. In addition to the direct economic benefits of surface water estimated in this study, there are additional sources of indirect and passive-use value, including the indirect benefits from goods and services provided by flood-irrigated pasture and passive-use values for migratory birds and native fish. Recreation on private land and other public land is also not included in this estimate. Therefore, the \$20.6 million annual economic benefit estimate for surface water used for pasture and recreation is conservative.

These activities also contribute to the regional economy. Pasture production and recreation in the basin support 804 jobs, \$14.5 million in labor income, \$47.3 million in economic output, and $\$ 26.2$ million in value added annually in the State of Oregon (table 24).
Table 23. Economic benefit by surface water use in the Harney Basin, Oreg.

[Benefit in 2020 dollars]

\begin{tabular}{lrr}
\hline \multicolumn{1}{c}{ Activity } & Unit value & Annual value \\
\hline Flood irrigation & $\$ 161.86$ per acre & $\mathbf{\$ 1 7 , 2 2 3 , 4 6 0}$ \\
Bird viewing & $\$ 52.16$ per day & $\mathbf{\$ 2 , 8 6 3 , 0 1 0}$ \\
Fishing & $\$ 65.85$ per day & $\mathbf{\$ 5 2 6 , 8 0 0}$ \\
\hline \multicolumn{1}{c}{ Total } & & $\mathbf{\$ 2 0 , 6 1 3 , 2 7 0}$ \\
\hline
\end{tabular}

The economic contribution estimates include jobs and economic activity in both the basin and the rest of the State of Oregon. For recreational bird viewing and fishing, the vast majority of these contributions occur within Harney County (tables 17 and 21). For pasture production, our method does not allow us to separate Harney County results from the rest of the State, however we expect that most of these effects also occur in Harney County.

\section{Incentives for Conservation}

Financial incentives for conservation on private land are an opportunity to promote working landscapes and wildlife habitat (Steven and others, 2013). Payment for ecosystem services (PES) is a policy instrument to maintain or increase the production of ecosystem services on private land that provide

Table 24. Annual economic contribution by surface water use in the Harney Basin, Oreg.

[Contribution in 2020 dollars]

\begin{tabular}{lccrrr}
\hline \multicolumn{1}{c}{ Use } & Supporting jobs & Labor income & Economic Output & Value added \\
\hline Flood irrigation & 718 & $\$ 11,639,511$ & $\$ 40,060,448$ & $\$ 22,107,492$ \\
Recreation-Bird viewing & 79 & $\$ 2,685,790$ & $\$ 6,813,970$ & $\$ 3,892,747$ \\
Recreation-Fishing & 6 & $\$ 160,157$ & $\$ 417,816$ & $\$ 224,681$ \\
\hline \multicolumn{1}{c}{ Total } & $\mathbf{8 0 4}$ & $\mathbf{\$ 1 4 , 4 8 5 , 4 5 9}$ & $\mathbf{\$ 4 7 , 2 9 2 , 2 3 4}$ & $\mathbf{\$ 2 6 , 2 2 4 , 9 2 0}$ \\
\hline
\end{tabular}


societal benefit. In the basin, habitat for migratory birds or native fish are examples of ecosystem goods that are affected by flood-irrigated pasture used in cow-calf operations. However, for example, agricultural producers are unable to capture the full economic benefit of the migratory bird habitat and thus may not completely consider the joint agricultural and habitat production benefits in management decisions (Kroeger and Casey, 2007). The full migratory bird habitat benefit is an aggregation of recreational benefits that occur in the basin, the indirect regional benefits associated with recreation and hunting outside of the basin, and the passive-use benefits of maintaining migratory bird abundance along the flyway. Therefore, migratory bird habitat has recreational benefits in and outside of the basin but also broader conservation benefits. Federal, State, and private organizations with a mission to maintain or increase migratory bird habitat may provide incentives for conservation, however, application of PES requires contextspecific design for program implementation.

In Harney County there may be an opportunity for PES when adjustments to on-farm irrigation practices, or abandonment of flood irrigation operations, alter the availability and quality of migratory bird or native fish habitat. Examples of conservation actions include updating diversion structures or implementing fish passage along irrigation channels. These infrastructure enhancements can improve the spreading of water across a floodplain and reduce labor through automation while also improving management of aquatic species in local streams and rivers. The focus of these types of infrastructure programs is to prevent conversion of flood-irrigated pasture to other irrigation types (for example, center pivot) or other land uses while improving both instream and wet meadow habitat. Even if conversion of flood-irrigated pasture to pivot irrigation does not occur over a significant share of parcels, fallowing or inactive flood management at the parcel level may have detrimental effects to migratory bird habitat. Other conservation efforts aim to improve migratory bird and fish habitat (and possibly forage production) through specific flood irrigation practices or delayed haying.

Currently, there are several State and Federal programs that invest in irrigation infrastructure modernization efforts in the basin. However, another option is for a PES program through direct private investments. For example, private investment would occur via recreational birders or hunters funding conservation for flood-irrigated pasture. Programs that rely on private donations to fund PES programs are limited (Chakrabarti and others, 2019). Difficulties with implementing a privately funded PES program include: (1) identifying the production of ecosystem goods and services from conservation practices; (2) estimating the economic benefit associated with the ecosystem service, typically a nonmarket good or service; and (3) overcoming the public good aspects of the ecosystem good or services (Kroeger and Casey, 2007). It is difficult to estimate the impact of basin flood-irrigated pasture on the production and abundance of migratory birds. While the basin provides critical habitat in the migratory flyway, the overall production of migratory birds is a function of multiple factors across the landscape (Bagstad and others, 2019; Haefele and others, 2019). However, the maintenance of habitat for migratory birds in the basin is potentially a critical conservation effort as habitat within and outside of the basin is altered due to human development and drought conditions exacerbated by climate change (Udall and Overpeck, 2017).

In our assessment of the economic benefit of bird viewing, the willingness to pay above and beyond trips costs totals approximately $\$ 2.8$ million. The challenge in the basin is to determine how to capture this benefit given bird watching is a quasi-public good. For example, bird viewing does not distract from others' viewing opportunities (excluding potential crowding effects) and there are limited opportunities to exclude those who do not pay for refuge or other forms of access given public roads provide several opportunities for viewing. This public good characteristic of bird viewing, and to some extend fishing, make private PES a challenge.

In the following sections, we discuss the ongoing PES through the State and Federal funding in the basin. To our knowledge, State and Federal payments in the basin for infrastructure improvements are currently the only PES occurring in the basin. We also discuss possible approaches to PES through private individuals. There is only one program we are aware of that uses payments from private individuals for conservation of birds, and it is outside of the basin (Chakrabarti and others, 2019). However, in addition to this example, we provide possible approaches to capturing the recreational benefits of bird viewing in the basin for conservation.

\section{PES and Agricultural Land}

There are several examples throughout the United States where State or Federal agencies make payments to maintain or improve ecosystem goods and services such as wildlife habitat on agricultural lands. The government organizations that fund these programs include the USDA Conservation Security Program, USDA Wildlife Habitat Incentives Program, USDA Environmental Quality Incentives Program (EQIP), FWS Partners for Fish and Wildlife and Landowner Incentive Programs (Casey and others, 2006), and States' public payment programs for the restoration or conservation of wildlife habitat. Goldstein and others (2011) examine three case studies of PES: nutrient retention in the Everglades; offsetting lost habitat for the endangered golden-cheeked warbler on private rangelands adjacent to Fort Hood Army Base; and credits to landowners in the Willamette Basin in Oregon for wetlands, salmon habitat, upland prairie habitat and preservation of water temperatures suitable for fisheries. There are also several case studies where PES is used to improve migratory bird habitat. Examples include incentives for habitat management and enhancement in Texas to create a migratory bird habitat mitigation bank for Federal projects; the Nature Conservancy and California Rice Commission incentivizing producers to maintain migratory bird habitat for approximately 4-8 weeks; and nonprofits, California dairy farmers, and government agencies compensating producers for unharvested 
acres. All these programs receive Federal funds to incentivize conservation of targeted migratory bird habitat. In general, the programs incentivize agricultural producers to alter management practices to improve habitat, including protecting nesting habitat through delayed or halted harvesting.

In the basin there is ongoing PES in the form of State and Federal funding for irrigation infrastructure improvements. The USDA EQIP, Ducks Unlimited, Intermountain West Joint Venture, Oregon Watershed Enhancement Board, and other organizations have partnered to provide financial and technical assistance to landowners in the basin to maintain and improve ecosystem services, such as wildlife habitat. Since 2014, for example, Ducks Unlimited has partnered with NRCS and the Oregon Watershed Enhancement Board to support more than $\$ 300,000$ in conservation projects on approximately 1,800 acres in Harney County, Oreg., (C. Colson, personal communication, July 7, 2020). This financial and technical assistance improves irrigation infrastructure and is intended to improve the spreading of surface water across wet meadow habitats, reduce labor costs, and ultimately retain flood-irrigated pasture by discouraging land-use conversion. The infrastructure improvements also include the construction of fish diversion and passage which improves native fish conditions.

\section{PES and Recreation}

PES by private individuals to landowners is much less common than conservation funding from State and Federal agencies. However, there is a potential to fund PES programs through private contributions. Payments from recreational users, for example, could come from entrance fees; charges for specific activities; additional fees for accommodations, concessions, or leasing; and sale of commodities specific to recreational groups (Steven and others, 2013). The Bobolink Project is one example where funding from private individuals has been used to incentivize conservation. In Rhode Island and Vermont, and now in other States, an online market was developed to elicit funds from recreationists and hunters to support habitat preservation for migratory birds, primarily through delayed haying to protect nests (Chakrabarti and others, 2019). This market-like program used crowdsourcing to provide payment through earmarks (payments for specific projects) and an auction system, incentivizing landowners to be as cost-effective as possible.

One of the difficulties in these programs is demonstrating to private funders that conservation will improve habitat and population responses (Mattsson and others, 2020). In the basin there are three possible scenarios where private PES might improve the joint outcome of cow-calf operations and the provision of ecosystem services in the form of native fish and migratory bird habitat. The first possible PES is foregoing the diversion of surface water in low water years for redband trout habitat protection. This is of a limited scope given redband trout habitat does not typically intersect with reaches of waterbodies used for flood irrigation. The second possible PES is for the maintenance of wet meadow habitat, assuming long-run sustainability of flood-irrigation on some parcels of land is unsustainable due to hydrology or regional and international commodity markets. The third option for PES is to incentivize agricultural producers to alter management actions such as delaying cutting or shifting agricultural production practices to minimize impact to or improve wet meadow habitat. For example, by delaying harvest for nesting or implementing early or multiple cuttings, changing the dynamics of habitat use, soil health, species composition, and yield may improve wet meadow habitat. Each opportunity for conservation would require monitoring and research to identify the result of conservation actions and agricultural practices that would maximize the value of jointly producing forage and wet meadow habitat for migratory birds.

Another challenge in private PES programs is to reduce transaction costs associated with private individuals paying landowners for ecosystem services. To avoid this, the Bobolink Project used a crowdsourcing platform. This reduced transaction costs and, through earmarks and auctions, improved the legitimacy and efficiency of the program. Another approach may be to organize landowners in the basin and provide a single contact location, such as a visitor center, to collect donations or sell access for bird viewing on private land. For example, recreational birders could pay for private land access at a visitor center to access multiple private parcels. An organized and coordinated effort would reduce transaction costs but also add a layer of legitimacy and provide opportunities to demonstrate cost-effective approaches to conservation, similar to Bobolink's crowdsourcing effort. The coordinated landowner effort would also provide a venue (either through a storefront or online) to market recreational merchandise that might also capture existing recreational benefits.

The other challenge in a private PES program is the public-good nature of conservation of migratory bird habitat. Public goods are those goods or services that, when consumed, do not significantly detract from others' participation or consumption. An exception in the case of bird viewing is crowding. However, this may occur only at specific viewing sites with ready access. The other aspect of a public good is the lack of ability to exclude consumers from the good or service. In this case of bird viewing in the basin, access to public roads along private and public land makes it difficult to limit viewing access. However, there may be opportunities in the basin to provide exclusive access to bird viewing on private land, for example through entry fees or charges for private land access. The coordination of landowners, reducing transaction costs, would be an important component of a privately funded PES design.

There are limited examples of private PES programs in the literature. However, there are opportunities for creative programs to capture benefits of bird viewing for conservation. These programs will need to coordinate landowners and recreational birders and credibly demonstrate that the incentives for conservation are promoting cost-effective solutions that are meeting conservation goals, all while adding value to the recreational bird-viewing experience. 


\section{Conclusion}

Surface water is used for a variety of complimentary and competing purposes in the Harney Basin. The production of wet meadow pasture and migratory bird habitat in the basin are complimentary uses of surface water. However, the "optimization" of this joint production requires additional monitoring and research. The production of wet meadow pasture and habitat for redband trout are competing uses of surface water. However, there is limited geographic scope where these competing uses occur.

In this paper, we estimate the economic benefit and contributions of surface water for flood-irrigated pasture and recreation in the Harney Basin. We estimate the economic benefit of surface water for flood irrigation to be approximately $\$ 160$ per acre, translating to an annual average of $\$ 17.2$ million in economic benefit. The grazing activity on the flood-irrigated pasture supports 718 jobs in the State of Oregon, most of which we predict are in Harney County, as well as \$11.6 million in labor income, \$40.1 million in economic output, and \$22.1 million in value added.

The annual economic benefits of bird viewing and fishing are estimated to be $\$ 2.8$ million and $\$ 526,000$, respectively. These value estimates are conservative as they contain only direct use value, which is just one portion of total economic value, and do not include possible recreation on other public and private land. The visitor spending from bird viewing and fishing supports 85 jobs, $\$ 2.8$ million in labor income, $\$ 7.2$ million in economic output, and $\$ 4.1$ million in value added. The vast majority of these contributions occur inside Harney County.

Together, these uses of surface water represent approximately $\$ 20$ million in economic benefit and support 803 jobs and over $\$ 47$ million in economic output in the State of Oregon. We estimate value and contributions from each of these uses separately, but the production of these goods and services are not independent from one another. Irrigated pasture and bird habitat are largely complementary surface water uses - the flood irrigation practice helps create and maintain the wet meadow habitat necessary for nesting birds. These two uses and their values and contributions are deeply intertwined. However, in very limited instances, irrigated pasture and bird habitat may represent a competing use to fish habitat, as the withdrawals necessary for wet meadow flooding leave less water instream.

While there are many different opportunities to improve the joint production of forage and habitat, including the capture of benefits from private recreation to improve conservation on private land, there are three challenges that could be addressed on an ongoing basis to improve conservation outcomes (Kroeger and Casey, 2007):

The first challenge is the ability to identify benefits, for example bird abundance, related to conservation activities. It will be important in the long run, considering the investment of capital and viability of species over time, to have measurable outcomes associated with joint production of birds and forage under various management approaches. This includes identifying cost-effective conservation and estimating the value of irrigated pasture and its spatial variation owing to changes in surface water management and (or) climate induced changes in hydrology.

The second challenge is to maintain an understanding of the willingness to pay for bird viewing and recreational fishing in the Harney Basin. Continuing to identify and refine the willingness to pay of recreational birders and anglers will provide basic information related to consumer surplus. This approach will allow managers in the basin to understand where there are opportunities to capture surplus value for conservation.

The third challenge is to understand the public good structure of bird viewing and fishing and develop creative ways to approach the issue of capturing consumer surplus. This will require close coordination between landowners along with public agencies.

Surface water in the Harney Basin holds significant value for agricultural and recreational use. Enhancing the joint production of goods and services with surface water will require continued monitoring and research associated with the agricultural, ecological, and economic aspects of such practices. There are opportunities through State or Federal programs and potentially landowner and private recreation cooperation to enhance the production of goods and services linked with surface water in the basin.

\section{References}

Aiken, R., 2009, Net economic values for wildlife-related recreation in 2006-Addendum to the 2006 National Survey of Fishing, Hunting and Wildlife-Associated Recreation: Washington, D.C., U.S. Fish and Wildlife Service, Report 2006-5, 28 p.

Aiken, R., and La Rouche, G.P, 2003, Net economic values for wildlife-related recreation in 2001-Addendum to the 2001 National Survey of Fishing, Hunting and Wildlife-Associated Recreation: Washington D.C., U.S. Fish and Wildlife Service, Report 2001-3, 24 p.

Bagstad, K.J., Semmens, D.J., Diffendorfer, J.E., Mattsson, B.J., Dubovsky, J., Thogmartin, W.E., Wiederholt, R., Loomis, J., Bieri, J.A., Sample, C., and Goldstein, J., 2019, Ecosystem service flows from a migratory species-Spatial subsidies of the northern pintail: Ambio, v. 48 , no. 1 , p. 61-73.

Bastian, C.T., McLeod, D.M., Germino, M.J., Reiners, W.A., and Blasko, B.J., 2002, Environmental amenities and agricultural land values-A hedonic model using geographic information systems data: Ecological Economics, v. 40, no. 3, p. 337-349.

Bell, K., Huppert, D., and Johnson, R.L., 2002, Willingness to pay for local coho salmon enhancement in coastal communities: Marine Resource Economics, v. 18, no. 1, p. 15-31. 
Berrens, R.P., Ganderton, P., and Silva, C.L., 1996, Valuing the protection of minimum instream flows in New Mexico: Journal of Agricultural and Resource Economics, v. 21, no. 2, p. 294-309.

Boyle, K.J., and Bishop, R.C., 1987, Valuing wildlife in benefit-cost analysis - A case study involving endangered species: Water Resources Research, v. 23, no. 5, p. 943-950.

Bowker, J.M., and Stoll, J.R., 1988, Use of dichotomous choice nonmarket methods to value the whooping crane resource: American Journal of Agricultural Economics, v. 70, no. 2, p. 372-381.

Britton, C., Cornely, J.E., and Sneva, F.A., 1980, Burning, haying, grazing and non-use of flood meadow vegetation in 1980 Progress Report-Research in rangeland management: Corvallis, Oreg., Oregon Agricultural Experiment Station, report no. 586, p. 7-9. [Also available at https://agsci. oregonstate.edu//sites/agscid7/files/eoarc/attachments/211c. pdf.]

Brown, T.C., Bergstrom, J.C., and Loomis, J.B., 2007, Defining, valuing, and providing ecosystem goods and services: Natural Resources Journal, v. 47, no. 2, p. 329-376.

Cameron, T.A., and Huppert, D.D., 1989, OLS versus ML estimation of non-market resource values with payment card interval data: Journal of Environmental Economics and Management, v. 17, no. 3, p. 230-246.

Casey, F., Vickerman, S., Hummon, C., and Taylor, B., 2006, Incentives for biodiversity conservation-An ecological and economic assessment: Washington, D.C., Defenders of Wildlife, $92 \mathrm{p}$.

Caudill, J., and Carver, E., 2019, Banking on nature 2017: The economic contributions of National Wildlife Refuge recreational visitation to local communities: Falls Church, Va., U.S. Fish and Wildlife Service, 32 p.

Chakrabarti, A., Chase, L., Strong, A.M., and Swallow, S.K., 2019, Making markets for private provision of ecosystem services-The Bobolink Project: Ecosystem Services, v. 37, article 100936, $11 \mathrm{p}$.

Champ, P.A., Boyle, K.J., and Brown, T.C., 2017, A primer on nonmarket valuation ( $2 \mathrm{~d}$ ed.), v. 13 of The economics of non-market goods and resources: The Netherlands, Springer, $504 \mathrm{p}$.

Clouse, C., 2020a, MRIO: Introduction to multi-regional input-output analysis: IMPLAN web page, accessed January 28, 2020, at https://implanhelp.zendesk.com/hc/en-us/ articles/115009713448-MRIO-Introduction-to-MultiRegional-Input-Output-Analysis.

Clouse, C., 2020b, MRIO: Multi-regional input-output analysis FAQ: IMPLAN web page, accessed January 28, 2020, at https://implanhelp.zendesk.com/hc/en-us/ articles/115009510987-MRIO-Multi-Regional-Input-Output-Analysis-FAQ.
Cooper, R.M., 2002, Determining surface water availability in Oregon: Oregon Water Resources Department, Open File Report SW 02-002, 158 p.

Cullinane Thomas, C., Koontz, L., and Carnachione, E., 2019, 2018 National park visitor spending effects - Economic contributions to local communities, States, and the Nation: National Park Service, Natural Resource Report NPS/ NRSS/EQD/NRR—2019/1922, 55 p.

Cummings, R.G., Ganderton, P.T., and McGuckin, T., 1994, Substitution effects in CVM values: American Journal of Agricultural Economics, v. 76, p. 205-214.

de Groot, R.S., Wilson, M.A., and Boumans, R.M.J., 2002, A typology for the classification, description and valuation of ecosystem functions, goods and services: Ecological Economics, v. 41, no. 3, p. 393-408.

Dieter, C.A., Maupin, M.A., Caldwell, R.R., Harris, M.A., Ivahnenko, T.I., Lovelace, J.K., Barber, N.L., and Linsey, K.S., 2018, Estimated use of water in the United States in 2015: U.S. Geological Survey Circular 1441, 65 p., https:// doi.org/10.3133/cir1441.

Dillman, D.A., 2007, Mail and internet surveys-The tailored design method (2d ed.): Hoboken, N.J., John Wiley and Sons, Inc., $480 \mathrm{p}$.

Dissanayake, S.T., and Ando, A.W., 2014, Valuing grassland restoration-Proximity to substitutes and trade-offs among conservation attributes: Land Economics, v. 90, no. 2, p. 237-259.

Donnelly, J.P., Naugle, D.E., Collins, D.P., Dugger, B.D., Allred, B.W., Tack, J.D., and Dreitz, V.J., 2019, Synchronizing conservation to seasonal wetland hydrology and waterbird migration in semi-arid landscapes: Ecosphere, v. 10 , no. 6 .

Duffield, J.W., and Patterson, D.A., 1992, Field testing existence values - Comparison of hypothetical and cash transaction values - Benefits and Costs in Natural Resource Planning (5th report): Corvallis, Oreg., Oregon State University, Western Regional Research Publication W-133.

Duffy, J.E., 2009, Why biodiversity is important to the functioning of real-world ecosystems: Frontiers in Ecology and the Environment, v. 7, no. 8, p. 437-444.

Freeman, A.M., III, 2003, The measurement of environmental and resource values - Theory and methods ( $2 \mathrm{~d}$ ed.): Washington D.C., Resources for the Future Press, 496 p.

Gascoigne, W.R., Hoag, D., Koontz, L., Tangen, B.A., Shaffer, T.L., and Gleason, R.A., 2011, Valuing ecosystem and economic services across land-use scenarios in the Prairie Pothole region of the Dakotas, USA: Ecological Economics v. 70 , no. 10 , p. $1715-1725$.

Gibbons, D.C., 1986, The economic value of water (1st ed.): Washington, D.C., Resources for the Future Press, 116 p. 
Goldstein, J.H., Presnall, C.K., López-Hoffman, L., Nabhan, G.P., Knight., R.L., Ruyle, G.B., and Toombs, T.P., 2011, Beef and beyond-Paying for ecosystem services on western US rangelands: Rangelands, v. 33, no. 5, p. 4-12.

Gomm, F.B., 1979, Climate and agriculture of Malheur-Harney Basin, Oregon: Corvallis, Oreg., Oregon State University Agricultural Experiment Station, Special Report 530, $23 \mathrm{p}$.

Haab, T.C., and McConnell, K.E., 2002, Valuing environmental and natural resources-The econometrics of non-market valuation: Northampton, Mass., Edward Elgar Publishing, Inc., $352 \mathrm{p}$.

Haefele, M.A., Loomis, J.B., Lien, A.M., Dubovsky, J.A., Merideth, R.W., Bagstad, K.J., Huang, T.K., Mattsson, B.J., Semmens, D.J., Thogmartin, W.E., and Wiederholt, R., 2019, Multi-country willingness to pay for transborder migratory species conservation-A case study of northern pintails: Ecological Economics, v. 157, p. 321-331.

Huber, C., and Richardson, L., 2016, Facilitating the inclusion of nonmarket values in Bureau of Land Management planning and project assessments-Final report: U.S. Geological Survey Open-File Report 2016-1178, 79 p., https://doi. org/10.3133/ofr20161178.

Huber, C., Cullinane Thomas, C., Meldrum, J.R., Meier, R., and Bassett, S., 2019, Economic effects of wildfire risk reduction and source water protection projects in the Rio Grande River Basin in northern New Mexico and southern Colorado: U.S. Geological Survey Open-File Report 2019-1108, 8 p., https://doi.org/10.3133/ofr20191108.

Hungate, B.A., Barbier, E.B., Ando, A.W., Marks, S.P., Reich, P.B., van Gestel, N., Tilman, D., Knops, J.M.H., Hooper, D.U., Butterfield, B., and Cardinale, B.J., 2017, The economic value of grassland species for carbon storage: Science Advances, v. 3, no. 4, article e1601880, 8 p.

IMPLAN Group LLC., 2018, IMPLAN System (data and software) 2017 national data set: Huntersville, N.C., IMPLAN, accessed January 28, 2020, at https://www.implan.com.

Johnson, K.A., Dalzell, B.J., Donahue, M., Gourevitch, J., Johnson, D.L., Karlovits, G.S., Keeler, B., and Smith, J.T., 2016, Conservation Reserve Program (CRP) lands provide ecosystem service benefits that exceed land rental payment costs: Ecosystem Services, v. 18, p. 175-185.

Johnston, R.J., Rolfe, J., Rosenberger, R., and Brouwer, R., eds., 2015, Benefit transfer of environmental and resource values, v. 14: New York, Springer, p. 582.

Kotchen, M.J., and Reiling, S.D., 2000, Environmental attitudes, motivations, and contingent valuation of nonuse values-A case study involving endangered species: Ecological Economics, v. 32, p. 93-107.
Kroeger, T., and Casey, F., 2007, An assessment of market based approaches to providing ecosystem services on agricultural lands: Ecological Economics, v. 64, no. 2, p. 321-332.

Layton, D.F., Brown Jr., G.M., and Plummer, M.L., 2001, Valuing multiple programs to improve fish populations: Washington State Department of Ecology, 25 p.

Loomis, J.B., 1996, Measuring the economic benefits of removing dams and restoring the Elwha River-Results of a contingent valuation survey: Water Resources Research, v. 32 , no. 2 , p. $441-447$.

Loomis, J., 2002, Integrated public lands management (2 ed.): New York, Chichester, West Sussex, Columbia University Press, 544 p.

Loomis, J., and Ekstrand, E., 1997, Economic benefits of critical habitat for the Mexican spotted owl-A scope test using a multiple-bounded contingent valuation survey: Journal of Agricultural and Resource Economics, v. 22, no. 2, p. 356-366.

Loomis, J.B., and Walsh, R.G., 1997, Recreation economic decisions - Comparing benefits and costs: State College, Pa., Venture Publishing, 440 p.

Malheur National Wildlife Refuge [MNWR] and U.S. Fish and Wildlife Service [FWS], 2013, Malheur National Wildlife Refuge Comprehensive Conservation Plan [CCP]: U.S. Fish and Wildlife Service. [Also available at https://www. fws.gov/refuge/Malheur/what_we_do/conservation.html.]

Mattsson, B.J., Devries, J.H., Dubovsky, J.A., Semmens, D., Thogmartin, W.E., Derbridge, J.J., and Lopez-Hoffman, L., 2020, Linking landscape-scale conservation to regional and continental outcomes for a migratory species: Scientific Reports, v. 10, article 4968, 16 p., https://doi.org/10.1038/ s41598-020-61058-3.

Maupen, M.A., Kenny, J.F., Hutson, S.S., Lovelace, J.K., Barber, N.L., and Linsey, K.S., 2014, Estimated use of water in the United States in 2010: U.S. Geological Survey Circular $1405,56 \mathrm{p}$.

National Agricultural Statistics Service [NASS], 2019, 2017 Census of Agriculture [COA] County Profile-Harney County, Oregon: U.S. Department of Agriculture National Agricultural Statistics Service, 2p. [Also available at https:// www.nass.usda.gov/Publications/AgCensus/2017/Online Resources/County_Profiles/Oregon/cp41025.pdf.]

National Agricultural Statistics Service [NASS], 2020, CropScape - Cropland data layer: U.S. Department of Agriculture National Agricultural Statistics Service database, accessed April 1, 2020, at https://nassgeodata.gmu.edu/ CropScape/. 
Olsen, D., Richards, J., and Scott, R.D., 1991, Existence and sport values for doubling the size of Columbia river basin salmon and steelhead runs: Rivers, v. 2, no. 1, p. 44-56.

Oregon Department of Agriculture, 2020, Greater Harney Basin agricultural water quality management area plan: Salem, Oreg., Oregon Department of Agriculture, 51 p.

Oregon Department of Fish and Wildlife, 1980, Fish Management Plan-Blitzen River: Salem, Oreg., Oregon Department of Fish and Wildlife, Fish Division, 6 p. [Also available at https://nrimp.dfw.state.or.us/DataClearinghouse/ default.aspx?p=202\&XMLname=41213.xml.]

Oregon Water Resources Department, 2020, Water Availability Reporting System: Oregon Water Resources Department database, accessed February 27, 2020, at https://apps.wrd. state.or.us/apps/wars/wars_display_wa_tables/download data.aspx.

Power, A.G., 2010, Ecosystem services and agriculture-Tradeoffs and synergies: Philosophical Transactions of the Royal Society of London B: Biological Sciences, v. 365, p. 2959-2971.

Reaves, D.W., Kramer, R.A., and Holmes, T.P., 1999, Does question format matter? Valuing an endangered species: Environmental and Resource Economics, v. 14, p. 365-383.

Richardson, L., and Loomis, J., 2009, The total economic value of threatened, endangered and rare species-An updated meta-analysis: Ecological Economics, v. 68, p. $1535-1548$.

Rimbey, N.R., Torell, L.A., and Tanaka, J.A., 2007, Why grazing permits have economic value: Journal of Agricultural and Resource Economics, v. 32, no. 1, p. 20-40.

Rosenberger, R., 2015, Benefit transfer validity and reliability, in Johnston, R., Rolfe, J., Rosenberger, R., and Brouwer, R., eds., Benefit transfer of environmental and resource values - A guide for researchers and practitioners, v. 14 of The economics of non-market goods and resources: The Netherlands, Springer, p. 307-326.

Rosenberger, R.S., and Loomis, J.B., 2017, Benefit transfer, in Champ, P.A., Boyle, K.J., and Brown, T.C., eds., A primer on nonmarket valuation ( $2 \mathrm{~d}$ ed.), v. 13 of The economics of non-market goods and resources: The Netherlands, Springer, p. 431-462.

Rosenberger, R.S., White, E.M., Kline, J.D., and Cvitanovich, C., 2017, Recreation economic values for estimating outdoor recreation economic benefits from the National Forest System: Portland, Oreg., U.S. Department of Agriculture, Forest Service, Pacific Northwest Research Station, General Technical Report PNW-GTR-957, 33 p. [Also available at https://www.fs.usda.gov/treesearch/pubs/54602.]
Oregon State University, 2016, Recreation Use Values Database: Oregon State University, College of Forestry database, accessed August 28, 2017, at http://recvaluation.forestry. oregonstate.edu/.

Rubin, J., Helfand, G., and Loomis, J., 1991, A benefit-cost analysis of the northern spotted owl: Journal of Forestry, v. 89 , no. 12 , p. $25-30$.

Segerson, K., 2017, Valuing environmental goods and services-An economic perspective, in Champ, P.A., Boyle, K.J., and Brown, T.C., eds., A primer on nonmarket valuation ( $2 \mathrm{~d}$ ed.), v. 13 of The economics of non-market goods and resources: The Netherlands, Springer, p. 1-25.

Semmens, D.J., Diffendorfer, J.E., López-Hoffman, L., and Shapiro, C.D., 2011, Accounting for the ecosystem services of migratory species-Quantifying migration support and spatial subsidies: Ecological Economics v. 70, no. 12, p. 2236-2242.

Sexton, N.R., Dietsch, A.M., Don Carlos, A.W., Koontz, L.M., Solomon, A.N., and Miller, H.M., 2012a, National wildlife refuge visitor survey 2010/2011-Individual refuge results: U.S. Geological Survey Data Series 643, https://pubs.usgs. gov/ds/643/.

Sexton, N.R., Dietsch, A.M., Don Carlos, A.W., Miller, H.M., Koontz, L.M., and Solomon, A.N., 2012b, National wildlife refuge visitor survey 2010/2011-Individual refuge results: U.S. Geological Survey Data Series 685, https://pubs.usgs. gov/ds/685/.

Sneva, F.A., 1982, Diurnal variation of nitrogen in flood meadow vegetation, in 1983 Progress report-Research in rangeland management: Corvallis, Oreg., Oregon Agricultural Experiment Station, report no. 682, p. 40.

Steven, R., Castley, J.G., and Buckley, R., 2013, Tourism revenue as a conservation tool for threatened birds in protected areas: PloS ONE, v. 8, no. 5, 8 p.

Stevens, T.H., Echeverria, J., Glass, R.J., Hager, T., and More, T.A., 1991, Measuring the existence value of wildlifeWhat do CVM estimates really show?: Land Economics, v. 67 , no. 4 , p. $390-400$.

Torell, L.A., Dixon, B., and McCullom, D., 2012, The market value of ranches and grazing permits in New Mexico, 1996 to 2010: Las Cruces, N. Mex., New Mexico State University, Research Report 779, 32 p.

Turner, H., Blount, D., and Angell, R., 1993, Diet and performance of steers grazing eastern Oregon native flood meadows in EOARC Annual Report: Corvallis, Oreg., Oregon Agricultural Experiment Station, Special Report 923, p. 38-41 https://agsci.oregonstate.edu//sites/agscid7/ files/eoarc/attachments/373i.pdf. 
Udall, B., and Overpeck, J., 2017, The twenty-first century Colorado River hot drought and implications for the future: Water Resource Research, v. 53, p. 2404-2418.

U.S. Department of Agriculture [USDA] Agricultural Marketing Service, 2019, Market-Hay; Washington-Oregon (Columbia Basin): U.S. Department of Agriculture, Report 3058 (Slug ID), accessed March 12, 2020, at https://mymarketnews.ams.usda.gov/filerepo/reports.

U.S. Department of Agriculture [USDA] Economic Research Service [ERS], 2019, State-level normalized price received estimates for commodities (ERS report year $=2019$ ): National Agricultural Statistics Service, data product, accessed April 15, 2020, at https://www.ers.usda.gov/dataproducts/normalized-prices/.

U.S. Department of Agriculture [USDA] Forest Service [FS], 2019, Visitor use report, Malheur NF, National visitor use monitoring data collected FY2014: National Visitor Use Monitoring Program, 47 p. [Also available at https://apps. fs.usda.gov/nvum/results/ReportCache/2014_A06004_Master_Report.pdf.]

U.S. Department of Commerce, 2019, American Community Survey: U.S. Census Bureau database, accessed June 16, 2020, at https://www.census.gov/programs-surveys/acs/data. $\mathrm{htm}$. [Database moved by time of publication.]

U.S. Department of the Interior, U.S. Fish and Wildlife Service, and U.S. Department of Commerce U.S. Census Bureau, 2018, 2011 National survey of fishing, hunting, and wildlife-associated recreation: U.S. Fish and Wildlife Service report FHW/11-NAT (RV), 161 p. [Also available at https://www.census.gov/library/publications/2014/demo/ fhw-11-nat.html.]
U.S. Department of the Interior Office of Policy Analysis, 2020, U.S. Department of the Interior economic contributions report fiscal year 2019, $41 \mathrm{p}$. [Also available at https:// www.doi.gov/sites/doi.gov/files/econ-report-2019-final.pdf]

U.S. Water Resources Council, 1983, Economic and environmental principles and guidelines for water and related land resources implementation studies: Washington, D.C., U.S. Government Printing Office, p. 137.

Wallmo, K., and Lew, D.K., 2012, Public willingness to pay for recovering and downlisting threatened and endangered marine species: Conservation Biology, v. 26, no. 5, p. $830-839$.

Wallmo, K., and Lew, D.K., 2015, Public preferences for endangered species recovery-An examination of geospatial scale and non-market values: Frontiers in Marine Science, v. 2, article 55, 8 p, https://doi.org/10.3389/ fmars.2015.00055.

Welsh, M.P., and Poe, G.L., 1998, Elicitation effects in contingent valuation - Comparisons to a multiple bounded discrete choice approach: Journal of Environmental Economics and Management, v. 36, no. 2, p. 170-185.

White, E., Bowker, J.M., Askew, A.E., Langner, L.L., Arnold, J.R., and English, D.B.K., 2016, Federal outdoor recreation trends: effects on economic opportunities: Portland, Oreg., U.S Department of Agriculture, Forest Service, Pacific Northwest Research Station, General Technical Report PNW-GTR-945, 46 p. [Also available at https://www. fs.usda.gov/treesearch/pubs/53247.]

Young, R.A., and Loomis, J.B., 2014, Determining the economic value of water: concepts and methods ( $2 \mathrm{~d}$ ed.): New York, Resources for the Future Press, 358 p. 


\section{Appendix 1: Demographics of Harney County}

According to the U.S. Census Bureau, Harney County, Oreg., had a population of 7,228 people in 2018 and experienced a net decrease in population of 1.8 percent since 2010 (table 1.1) (U.S. Department of Commerce, 2019). Comparatively, Oregon's population has grown by 8.5 percent since 2010 to more than 4 million people in 2018. Per capita income and median household income for Harney County were $\$ 25,817$ and $\$ 41,797$, respectively; each income measure was lower than the overall State of Oregon's population at $\$ 32,045$ (per capita) and \$59,393 (median household). Harney County also had a slightly older population with a median age of 46.1 relative to Oregon's at 39.2 years of age. Approximately 91 percent of Harney County's population identified racially as "white alone," 5 percent identified as of Hispanic or Latino ethnicity, and 1.6 percent identified as being of Native
American origin. Harney County had 16.6 percent of people and 11.9 percent of families in poverty. This is slightly higher than Oregon with 14.1 percent of people and 9.2 percent of families in poverty in 2018. Approximately 90 percent the population aged 25 and over for both Harney County and the State of Oregon were high school graduates as of 2018 (fig. 1.1). Both Harney County and the State of Oregon have a similar proportion of those aged 25 and over with an associate's degree (9.6 percent in Harney County; 8.8 percent in Oregon). The main difference between Harney County and the State of Oregon as a whole is the proportion of those who had attained a bachelor's degree or higher (17 percent in Harney County; 33 percent in the State of Oregon) or who had attained a graduate or professional degree (5.8 percent in Harney County; 12.4 percent in Oregon).

Table 1.1. Population and demographic statistics for Harney County and the State of Oregon.

[Data from U.S. Department of Commerce (2019). \%, percent]

\begin{tabular}{|c|c|c|}
\hline Demographic Characteristics & Harney County & Oregon \\
\hline Population (2018) & 7,228 & $4,081,943$ \\
\hline Population (2010) & 7,364 & $3,761,925$ \\
\hline Population percent change (2010-2018) & $-1.8 \%$ & $8.5 \%$ \\
\hline Number of households (2018) & 3,157 & $1,591,835$ \\
\hline Per capita income (2018) & $\$ 25,871$ & $\$ 32,045$ \\
\hline Median household income (2018) & $\$ 41,797$ & $\$ 59,393$ \\
\hline Median age (2018) & 46.1 & 39.2 \\
\hline Percent of population who identify as "white alone" & $90.9 \%$ & $84.4 \%$ \\
\hline Percentage of population who identify as Hispanic or Latino (of any race) & $5.0 \%$ & $12.8 \%$ \\
\hline Percent of population who identifies as Native American & $1.6 \%$ & $1.2 \%$ \\
\hline Percentage of people below poverty level & $16.6 \%$ & $14.1 \%$ \\
\hline Percentage of families below poverty & $11.9 \%$ & $9.2 \%$ \\
\hline
\end{tabular}

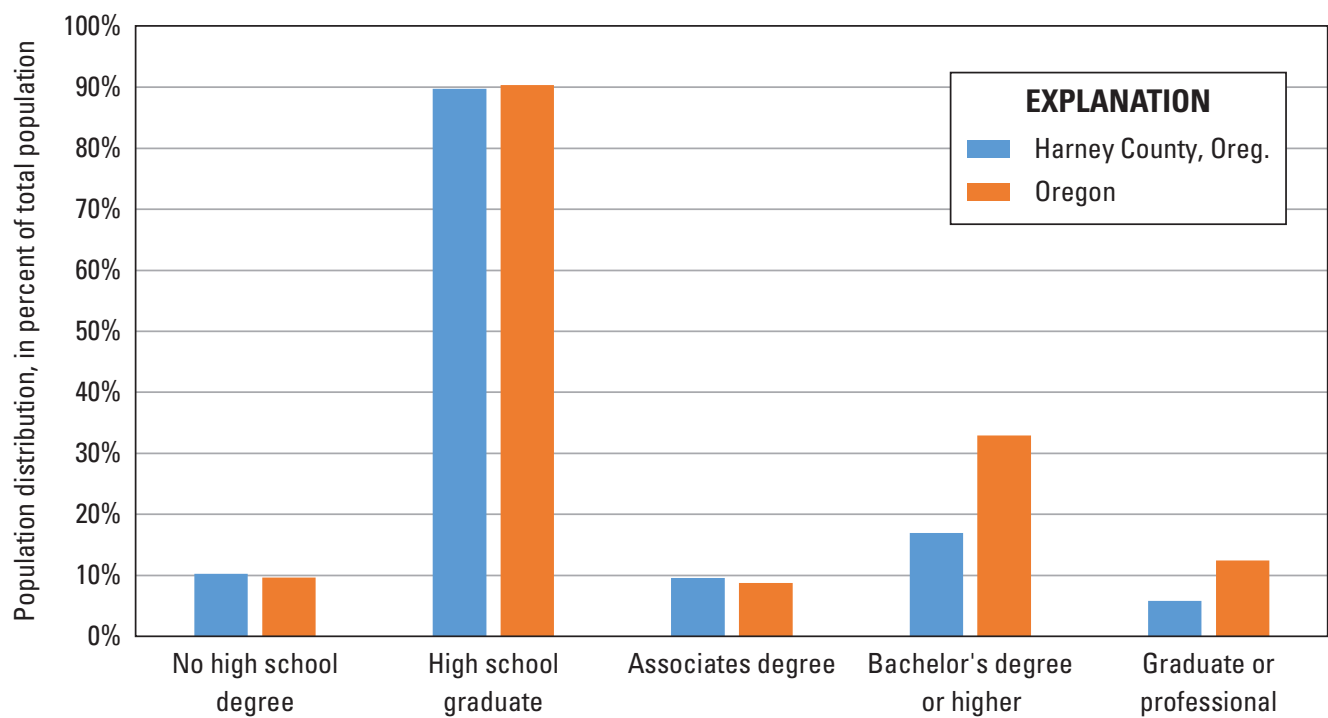

Figure 1.1. Population distribution of Harney County. Percentage of total population 25 years or older for Harney County, Oreg., and the State of Oregon who did not graduate high school (no high school degree), gradated high school (high school graduate), held an associate's degree, bachelor's degree or higher, or graduate or professional degree. 
The total number of civilian employees in Harney County in 2018 was 2,898 people (table 1.2). The distribution of civilian employees according to industry codes, based on the North American Industry Classification System (NAICS), reveals that approximately one quarter of employees are in the "education, health care, and social assistance" industry (https://www. census.gov/eos/www/naics/). This is followed by the "agriculture, forestry, fishing and hunting, and mining" industrial grouping. Comparatively, this grouping ("agriculture, forestry, fishing and hunting, and mining") has a higher percentage of civilian employees for Harney County (19.6 percent) than for the State of Oregon as a whole (3.2 percent), thus highlighting the relative importance of the industry to the local economy relative to other parts of the State. "Public administration" represents the next highest percentage of civilian employees at 12.1 percent, which is also a relatively higher frequency compared to the State of Oregon at 3.2 percent. This indicates that a higher proportion of Harney County employment is supported by local, State, and Federal government activities in the region relative to the rest of the State's economy.

Table 1.2. Total number of civilian employees (16 years and older) and percentage of employees by industry for Harney County and the State of Oregon.

[Data from U.S. Department of Commerce (2019). \%, percent]

\begin{tabular}{|c|c|c|}
\hline Industry & $\begin{array}{l}\text { Percentage of civilian employees } \\
\text { in Harney County }\end{array}$ & $\begin{array}{l}\text { Percentage of civilian employees } \\
\text { in Oregon }\end{array}$ \\
\hline Education, health care, and social assistance & $24.8 \%$ & $22.9 \%$ \\
\hline Public administration & $12.1 \%$ & $4.6 \%$ \\
\hline Retail trade & $8.8 \%$ & $11.7 \%$ \\
\hline Arts, entertainment, recreation, accommodations, and food & $6.3 \%$ & $9.9 \%$ \\
\hline Other services, except public administration & $5.4 \%$ & $4.7 \%$ \\
\hline Professional, management, administration, and waste management & $5.2 \%$ & $10.9 \%$ \\
\hline Wholesale trade & $3.1 \%$ & $2.8 \%$ \\
\hline Information & $0.6 \%$ & $1.8 \%$ \\
\hline Total number of civilian employees (16 years and older) (2018) & 2,898 & $1,934,643$ \\
\hline
\end{tabular}





\section{Appendix 2: Total Economic Value per Household for Fish Species}

Table 2.1. Total economic value per household for fish species.

[Willingness to pay in 2020 dollars; \%, percent]

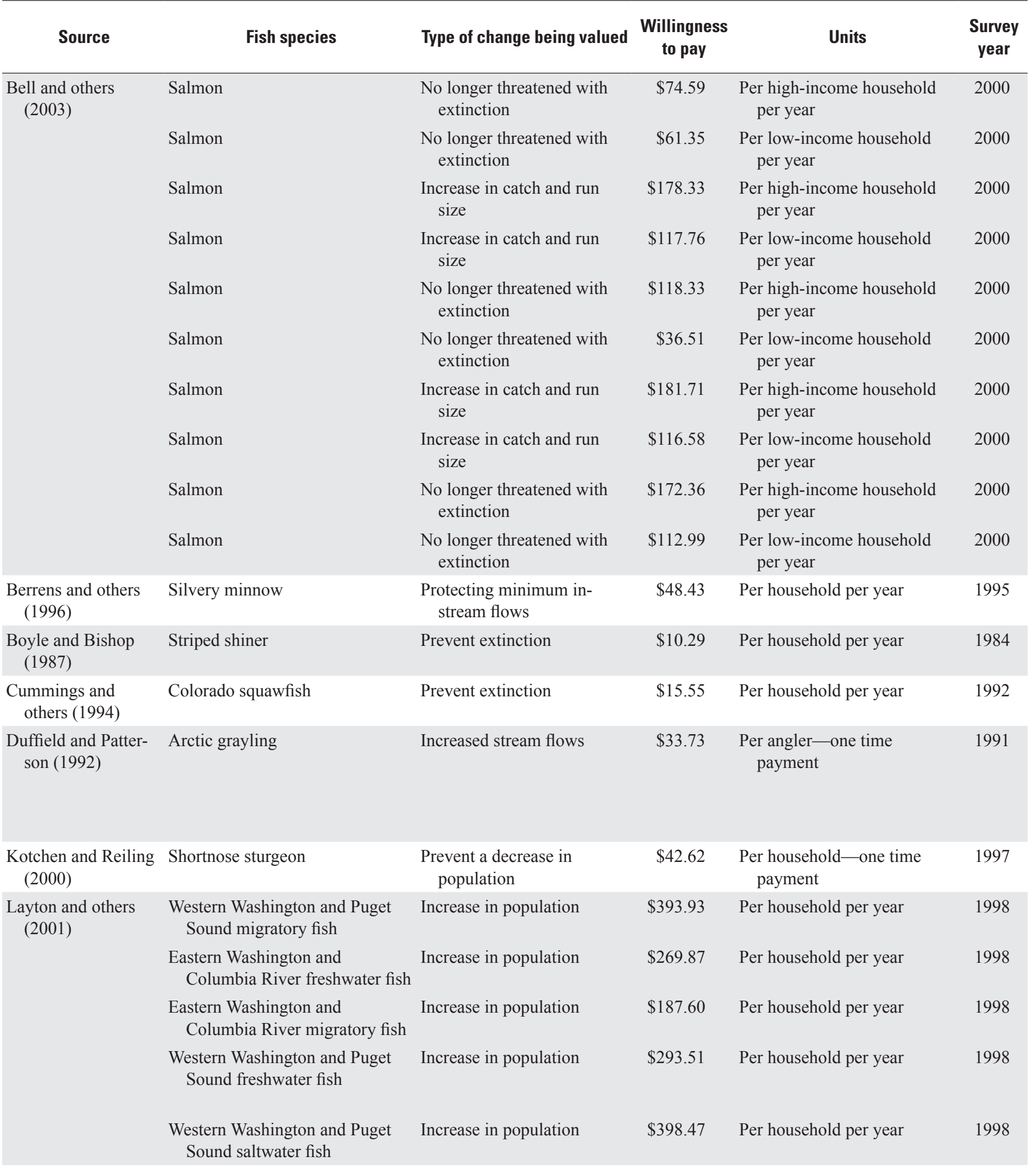




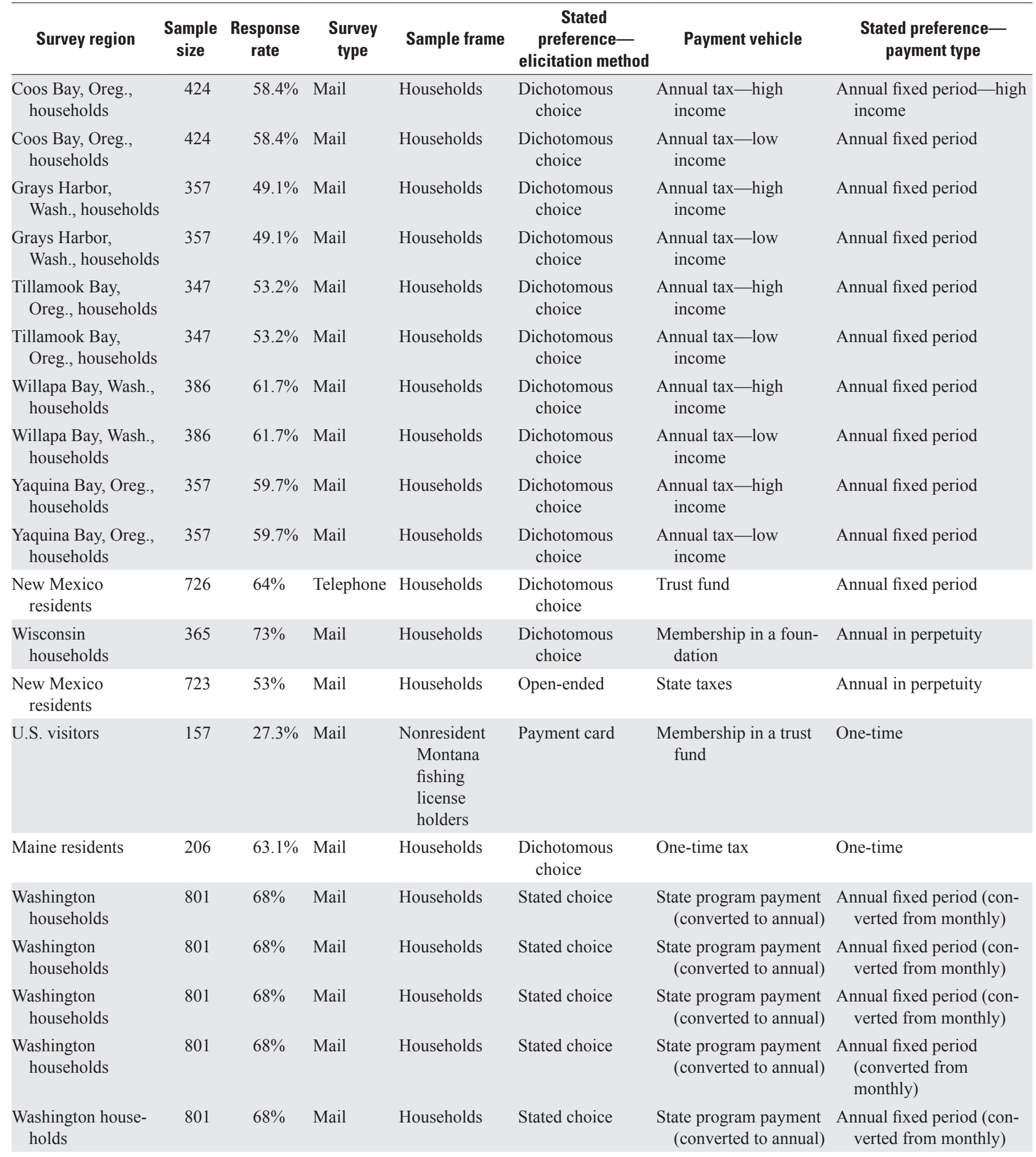


Table 2.1. - Continued

\begin{tabular}{|c|c|c|c|c|c|}
\hline Source & Fish species & Type of change being valued & $\begin{array}{l}\text { Willingness } \\
\text { to pay }\end{array}$ & Units & $\begin{array}{c}\text { Survey } \\
\text { year }\end{array}$ \\
\hline \multirow[t]{3}{*}{ Loomis (1996) } & Salmon and steelhead & Increase in population & $\$ 102.27$ & Per household per year & 1994 \\
\hline & Salmon and steelhead & Increase in population & $\$ 117.86$ & Per household per year & 1994 \\
\hline & Salmon and steelhead & Increase in population & $\$ 126.53$ & Per household per year & 1994 \\
\hline \multirow{2}{*}{$\begin{array}{l}\text { Olsen and others } \\
\text { (1991) }\end{array}$} & Salmon and steelhead & Increase in population & $\$ 154.69$ & Per angler per year & 1989 \\
\hline & Salmon and steelhead & Increase in population & $\$ 54.75$ & Per household per year & 1989 \\
\hline \multirow{2}{*}{$\begin{array}{l}\text { Stevens and others } \\
\text { (1991) }\end{array}$} & Atlantic salmon & Prevent extinction & $\$ 12.95$ & Per household per year & 1989 \\
\hline & Atlantic salmon & Prevent extinction & $\$ 14.40$ & Per household per year & 1989 \\
\hline \multirow[t]{4}{*}{$\begin{array}{l}\text { Wallmo and Lew } \\
\text { (2012) }\end{array}$} & $\begin{array}{l}\text { Upper Willammette River chi- } \\
\text { nook salmon }\end{array}$ & Recovery & $\$ 47.90$ & Per household for recovery & 2009 \\
\hline & Puget Sound chinook salmon & Recovery & $\$ 47.72$ & Per household for recovery & 2009 \\
\hline & Smalltooth sawfish & Recovery & $\$ 61.15$ & Per household for recovery & 2009 \\
\hline & Smalltooth sawfish & $\begin{array}{l}\text { Downlisted to threatened } \\
\text { status }\end{array}$ & $\$ 38.24$ & Per household for recovery & 2009 \\
\hline \multirow[t]{4}{*}{$\begin{array}{l}\text { Wallmo and Lew } \\
\text { (2015) }\end{array}$} & $\begin{array}{l}\text { Central California coast coho } \\
\text { salmon }\end{array}$ & Recovery & $\$ 60.17$ & Per household for recovery & 2010 \\
\hline & $\begin{array}{l}\text { Central California coast coho } \\
\text { salmon }\end{array}$ & Recovery & $\$ 68.54$ & Per household for recovery & 2010 \\
\hline & Southern California steelhead & Recovery & $\$ 83.74$ & Per household for recovery & 2010 \\
\hline & Southern California steelhead & Recovery & $\$ 91.40$ & Per household for recovery & 2010 \\
\hline
\end{tabular}




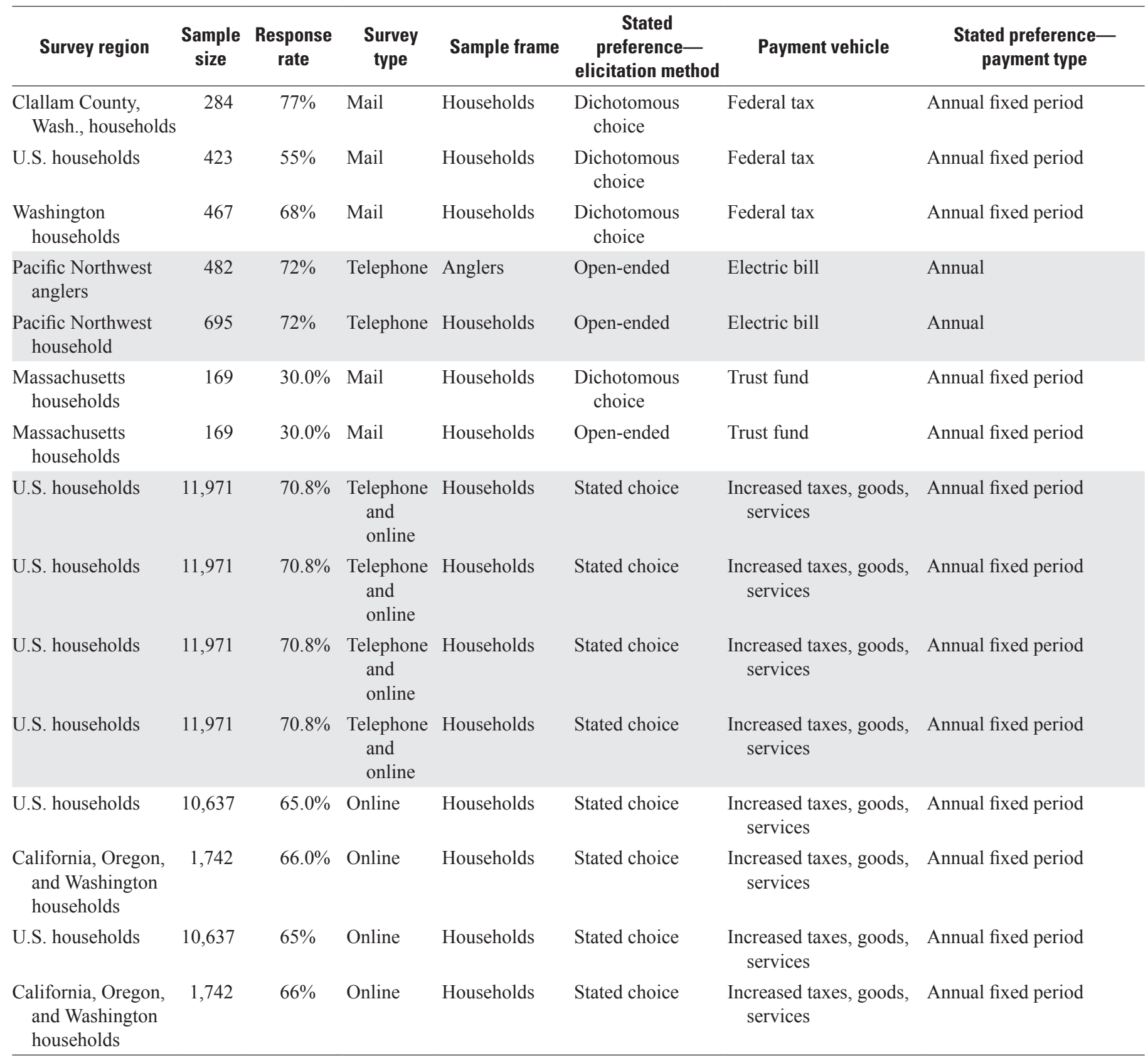



Moffett Field Publishing Service Center, California

Manuscript approved for publication August 27, 2021

Edited by Regan Austin

Layout and design by Kimber Petersen

Illustration support by JoJo Mangano 


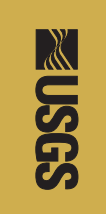

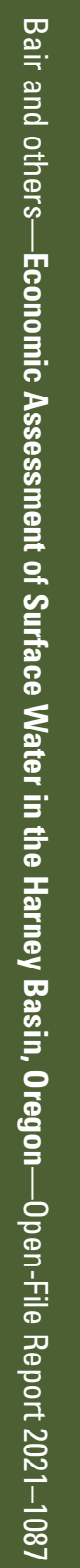

